Portland State University

PDXScholar

6-1-2017

\title{
Balance Sheet Effects on Monetary and Financial Spillovers: The East Asian Crisis Plus 20
}

Joshua Aizenman

University of Southern California

Menzie D. Chinn

Robert M. La Follette School of Public Affairs

Hiro Ito

Portland State University, ito@pdx.edu

Follow this and additional works at: https://pdxscholar.library.pdx.edu/econ_fac

Part of the Economics Commons

Let us know how access to this document benefits you.

\section{Citation Details}

Aizenman, J., Chinn, M. D., \& Ito, H. (2017). Balance sheet effects on monetary and financial spillovers: The East Asian crisis plus 20. Journal of International Money and Finance.

This Post-Print is brought to you for free and open access. It has been accepted for inclusion in Economics Faculty Publications and Presentations by an authorized administrator of PDXScholar. Please contact us if we can make this document more accessible: pdxscholar@pdx.edu. 
NBER WORKING PAPER SERIES

BALANCE SHEET EFFECTS ON MONETARY AND FINANCIAL SPILLOVERS: THE EAST ASIAN CRISIS PLUS 20

\author{
Joshua Aizenman \\ Menzie D. Chinn \\ Hiro Ito \\ Working Paper 22737 \\ http://www.nber.org/papers/w22737 \\ NATIONAL BUREAU OF ECONOMIC RESEARCH \\ 1050 Massachusetts Avenue \\ Cambridge, MA 02138 \\ October 2016
}

The financial support of faculty research funds of University of Southern California, the University of Wisconsin, Madison, and Portland State University is gratefully acknowledged. All remaining errors are ours. We would like to thank Kenichi Ueda and the participants at the Pacific Rim and the Global Economy University of Tokyo conference, July 25-26, 2016 for their useful comments. Any errors are ours. The views expressed herein are those of the authors and do not necessarily reflect the views of the National Bureau of Economic Research.

NBER working papers are circulated for discussion and comment purposes. They have not been peer-reviewed or been subject to the review by the NBER Board of Directors that accompanies official NBER publications.

(C) 2016 by Joshua Aizenman, Menzie D. Chinn, and Hiro Ito. All rights reserved. Short sections of text, not to exceed two paragraphs, may be quoted without explicit permission provided that full credit, including $\odot$ notice, is given to the source. 
Balance Sheet Effects on Monetary and Financial Spillovers: The East Asian Crisis Plus 20 Joshua Aizenman, Menzie D. Chinn, and Hiro Ito

NBER Working Paper No. 22737

October 2016

JEL No. F15,F2,F31,F36,F41

\begin{abstract}
We study how the financial conditions in the Center Economies [the U.S., Japan, and the Euro area] impact other countries over the period 1986 through 2015. Our methodology relies upon a two-step approach. We focus on five possible linkages between the center economies (CEs) and the non-Center economics, or peripheral economies (PHs), and investigate the strength of these linkages. For each of the five linkages, we first regress a financial variable of the PHs on financial variables of the CEs while controlling for global factors. Next, we examine the determinants of sensitivity to the CEs as a function of country-specific macroeconomic conditions and policies, including the exchange rate regime, currency weights, monetary, trade and financial linkages with the CEs, the levels of institutional development, and international reserves. Extending our previous work (Aizenman et al. (2016)), we devote special attention to the impact of currency weights in the implicit currency basket, balance sheet exposure, and currency composition of external debt. We find that for both policy interest rates and the real exchange rate (REER), the link with the CEs has been pervasive for developing and emerging market economies in the last two decades, although the movements of policy interest rates are found to be more sensitive to global financial shocks around the time of the emerging markets' crises in the late 1990s and early 2000s, and since 2008. When we estimate the determinants of the extent of connectivity, we find evidence that the weights of major currencies, external debt, and currency compositions of debt are significant factors. More specifically, having a higher weight on the dollar (or the euro) makes the response of a financial variable such as the REER and exchange market pressure in the PHs more sensitive to a change in key variables in the U.S. (or the euro area) such as policy interest rates and the REER. While having more exposure to external debt would have similar impacts on the financial linkages between the CEs and the PHs, the currency composition of international debt securities does matter. Economies more reliant on dollar-denominated debt issuance tend to be more vulnerable to shocks emanating from the U.S.
\end{abstract}

Joshua Aizenman

Economics and SIR

USC

University Park

Los Angeles, CA 90089-0043

and NBER

aizenman@usc.edu

Menzie D. Chinn

Department of Economics

University of Wisconsin

1180 Observatory Drive

Madison, WI 53706

and NBER

mchinn@lafollette.wisc.edu
Hiro Ito

Portland State University

1721 SW Broadway, Suite 241

Portland, Oregon 97201

ito@pdx.edu 


\section{Introduction}

On the eve of the 20th year anniversary of the East Asian crisis, we investigate the impact of balance sheet exposures, economic structure and trilemma choices on the exposure of countries to shocks emanating from the center. Events over recent decades have vividly illustrated that balance sheet exposure impact monetary and fiscal spaces, capital mobility, and exchange market pressure. The evolution of global dynamics during the post-Global Financial Crisis period led Rey (2013) to propound the hypothesis that exchange rate regimes no longer insulate countries from global financial cycles - in other words, the demise of the Mundellian Trilemma. In this paper, however, we investigate whether Rey's view means the end of the trilemma hypothesis or a prematurely prediction that is not supported by the data. In order to gain further insights regarding these developments, we examine how the financial conditions of - and shocks propagated from -- the Center Economies [dubbed CEs, namely the U.S., Japan, and the Euro area], impact the non CEs economics. Extending our previous work (Aizenman et al. (2016)), we devote special attention to the impact of currency weights in the implicit currency basket, balance sheet exposure, and currency composition of external debt.

Our empirical method relies upon a two-step approach. We first investigate the extent of sensitivity of policy interest rate, the real effective exchange rate (REER) and several other macro variables to those of the center economies while controlling for global factors. The estimation is done for the sample period is 1986 through 2015, using monthly data and in a rolling fashion. Next, we examine the association of these sensitivity coefficients with country's trilemma choices, the real and financial linkages with the $\mathrm{CE}$, the levels of institutional development, balance sheet exposure, and the like. Using the methodology of Frankel and Wei (1996), we estimate the currency weights of the non-ECs economies, and study the impact of these weights on the transmission of shocks from the ECs to non-ECs countries (or peripheral economies, "PHs").

We find that for both policy interest rates and the REER, the link with the CEs has been a dominant factor for developing and emerging market economies [EMGs] in the last two decades. Furthermore, the developing and EMGs policy interest rates are more sensitive to global financial shocks around the time of EMGs' crises in the period surrounding the turn of the century, and again since the Global Financial Crisis [GFC] of 2008. In contrast with Rey's conclusions, we find that the type of exchange rate regime and country's currency weights or 
currency composition in international debt do matter: developing countries or EMGs with more stable exchange rate and more open financial markets are more affected by changes in the policy interest rates in the CEs. Exchange rate stability, financial openness, and IR holding are jointly significant for the group of developing or emerging market countries.

Distinct from our earlier results, we find evidence that the weights of major currencies, the extent of external debt, and the currency composition of debt are significant factors. Having a higher weight of the dollar (or the euro) enhances the responsiveness of a financial variable such as PH REER and EMP to a change in key variables in the U.S. (or the euro area). While having more exposure to external debt has similar effects on the financial linkages between the CEs and the PHs, the currency composition of international debt securities has a differential impact. Those economies more reliant on the dollar for debt issuance tend to be more vulnerable to shocks occurring in the U.S.

In what follows, we present the framework of our main empirical analysis in Section 2. Each of the two steps for the estimation is explained in this section. In Section 3, we present empirical results for the baseline estimations. In Section 4, we focus on the impacts of currency weights, trade with currency zones, external debt, and currency composition of international debt. We make concluding remarks in Section 5.

\section{The Framework of the Main Empirical Analysis}

Methodologically, we extend the same approach as followed in Aizenman et al. (2016), with special focus on different determinants of linkage strength between the CEs and the PHs. To recap, our analytical process is similar to the two-step estimations employed by Forbes and Chinn (2004). As the first step, we focus on the five possible linkages between the PHs and the CEs and investigate the degree of the sensitivity through those linkages. For each of the five linkages, we regress a financial variable of the PHs on another (or the same) variable of the CEs while controlling for global factors. In the second step, we treat the estimated degree of sensitivity as the dependent variable, and examine their determinants among a number of country-specific variables, including the roles of countries' macroeconomic conditions or policies, real or financial linkage with the center economy, or the level of institutional development of the countries. In this study, our discussion centers on the effect of variables 
pertaining to balance sheets of the sample countries such as external debt, the weights of major currencies in the currency basket, and the share of currencies for debt denomination.

\subsection{The Five Linkages - The Channels through which PHs are Susceptible to Changes in CEs' Financial Conditions}

Before we investigate the linkages between the CEs and the PHs, we must identify what kind of linkages we focus on. In that regard, Figure 1 is helpful. It illustrates how the variables of our focus tend to be more affected by spillovers of shocks around the globe. More specifically, the five linkages between the CEs and the PHs are as follows.

Link 1 - Short-term, policy interest rate in the CEs $\rightarrow$ Short-term, policy interest rate in the PHs: If country $i$ has its monetary policy more susceptible to the monetary policy of one (or more) of the CEs, the correlation of the policy interest rates between the CEs and PHs should be significantly positive, implying a closer linkage between the CEs and PHs. However, a significantly negative correlation could also mean a closer linkage. If a rise in a CE's policy rate could draw capital from the PHs, that could reduce money demand among PHs and therefore lower the policy rates among them while the CEs experience a rise in both money demand and the policy rate, thus making the correlation negative. ${ }^{4}$

Link 2 - Short-term, policy interest rate in the CEs $\rightarrow$ REER in the PHs: A rise in the short-term interest rate in the CEs could be followed by a rise in PH's REER (i.e., real appreciation) if PHs pursue more stable exchange rate movements against the currencies of the CEs. If not, a rise in the short-term interest rate in the CEs could draw more capital from PHs, pushing down their REER.

Link $3-R E E R$ in the CEs $\rightarrow$ REER in the PHs: As was in the previous case, real appreciation (depreciation) of CEs' currencies can be followed by real appreciation (depreciation) of PHs' currencies, making the correlation positive, which is more likely if PHs pursue greater exchange rate stability. Or, highly indebted PHs may also try to have their REER

\footnotetext{
${ }^{4}$ In other words, if a rise (fall) of the short-term interest rates in the CEs is followed by a fall (rise) in the money growth (or supply) of the PHs, the correlation of the interest rates between the CEs and PHs will be positive. If a rise (fall) in the CEs' interest rates is followed by a fall (rise) in money demand among PHs (i.e., a fall in the policy rate), the correlation would be negative. The latter could more likely happen if PHs have more flexible exchange rate arrangements as we will see later on.
} 
to follow that of the CEs if their debt is denominated in the currencies of the CEs to prevent debt burden in their domestic currencies from rising.

Link 4 - Change in REER in CEs $\rightarrow$ the Exchange Market Pressure (EMP) in PHs:

When the CE's experience real appreciation of their currencies, given some price stickiness, that would create (expected) nominal depreciation pressure on a peripheral economy, raising the expected rate of return from holding CE's assets in terms of PH's currency. If the PHs does not pursue exchange rate fixity, its currency would depreciate. If it does pursue exchange rate fixity, then the PH's monetary authorities would intervene the foreign exchange market, decrease its holding of foreign reserves, and end up having a higher policy interest rate. Given that the EMP index is defined as a weighted average of monthly changes in the rate of depreciation, the percentage loss in international reserves, and the change in the nominal interest rate, whether PH's monetary authorities pursue exchange rate fixity (i.e., no currency depreciation but a rise in the interest rate and a reduction in IR holding) or not (i.e., currency depreciation with no or less change in the interest rate or IR holding), its EMP should rise. Hence, the CE's REER should be positively correlated with the non-center's EMP.

Link 5 - REER in CEs $\rightarrow$ Stock market prices in PHs: In 2013, the U.S. Federal Reserve hinted at the eventual taper in its purchases of long term Treasury's and agency bonds (i.e., quantitative easing $(\mathrm{QE}))$; that created downward pressure for some emerging market economies' currencies, and subsequent downturns in their respective equity markets. This "taper tantrum" episode and market jitters in the "Fragile Five" (i.e., Brazil, India, Indonesia, South Africa, and Turkey) constitutes the prime example of how a rise in the exchange rates of the CEs can lead to a fall in stock market prices of the PHs. Besides this kind of portfolio effect, it can be anticipated that currency appreciation of the CEs creates expected currency depreciation for the $\mathrm{PHs}$, and if the $\mathrm{PH}$ of concern is more often to international trade, currency depreciation would give exporters more trade competitiveness, so that stock market prices could rise, reflecting a rise in future income flows of the firms in the PH.

We estimate the five linkages with or sensitivity to the CEs' financial conditions by applying the same methodology as we employed in Aizenman et al. (2016). ${ }^{5}$

\footnotetext{
${ }^{5}$ Links 1 and 3 are already investigated in Aizenman, et al. (2015).
} 


\subsection{The First-Step: Estimating Sensitivity Coefficients}

The main objective of this first step estimation is to estimate the correlation between a financial variable of the CEs and another (or the same) financial variable of peripheral economy $i$, while controlling for global factors. We focus on the estimated coefficient $\hat{\gamma}_{F i}^{C}$ which represents the extent of sensitivity of the financial variable $Y_{i t}$ of country $i$ to another (or the same) financial variable $\left(X_{i t}^{C}\right)$ of each of the three CEs, i.e., the U.S., the Euro area, and Japan, as shown in (1): ${ }^{6}$

$$
Y_{i t}=\alpha_{F i t}+\sum_{g=1}^{G} \beta_{F i t}^{G} Z_{i t}^{G}+\sum_{c=1}^{C} \gamma_{F i t}^{C} X_{i t}^{C}+\varepsilon_{i t}
$$

where $Z_{i}^{G}$ is a vector of global factors, and $X_{i}^{C}$ is a vector of cross-country factors.

We estimate $\gamma_{i t}^{C}$ for the five linkages as we discussed in the previous subsection, using the following variables.

Table 1: Five Linkages and Corresponding Financial Variables (also see Figure 1)

\begin{tabular}{l|l|l}
\hline Link & Financial Variable in the CEs $\left(X^{C}\right)^{7}$ & Financial Variable in the PHs $(Y)$ \\
\hline Link 1 & Money market rate & Money market rate \\
Link 2 & Change in money market rate & Change in REER \\
Link 3 & Change in REER & Change in REER \\
Link 4 & Change in REER & Exchange market pressure (EMP) \\
Link 5 & Change in REER & Change in stock market prices \\
\hline
\end{tabular}

For money market rates that represent policy short-term interest rate, using official policy interest rates may not capture the actual state of monetary policy because all of the CEs have

\footnotetext{
${ }^{6}$ We do not include China as one of the CEs. Aizenman, et al. (2015) find that despite the recent impressive rise as an economic power, China's contribution in the financial sector still seems negligible in a historical context. Considering that the Shanghai stock market crash in the summer of 2015 and the winter of 2016 significantly affected financial markets in the U.S., Japan, and Europe, one expects that the role of China as a CE and connectivity with it will become substantial in the near future. The same kind of argument can be made about whether other large emerging market economies such as Brazil, Russia, and India can be the center economies that exert global influence. While their role as major economies in the world has been rising, we would still have to wait for future research to identify their increasing influence in the global economy.

${ }^{7}$ For the Euro Area's variables before the introduction of the euro in 1999, the GDP-weighted average of the variable of concern for the original 12 Euro countries is calculated and included in the estimation.
} 
implemented extremely loose monetary policy, whether conventional or unconventional one, in the aftermath of the GFC. ${ }^{8}$ Hence, we use the "shadow interest rates" to represent a more realistic state of liquidity availability for the three advanced economies. For the U.S. and the Euro area, we use the shadow interest rates estimated by Wu and Xia (2014). For Japan, we use the shadow rates estimated by Christensen and Rudebusch (2014).

For the stock market price indices as well as the REER, we use data from the IMF's International Financial Statistics (IFS). Also, we calculate the EMP index, using the data for policy interest rates, nominal exchange rates, and international reserves from the IFS. For more details on the EMP, refer to Data Appendix.

We also have global factors $\left(Z_{i}^{G}\right)$ as a group of control variables in the estimation. The vector of "real" variables includes global interest rates (for which we use the first principal component of U.S. Federal Reserve, ECB, and Bank of Japan's policy interest rates); oil prices; and commodity prices. ${ }^{9} Z_{i}^{G}$ also comprises another vector of "financial" global factors, namely, the VIX index from the Chicago Board Options Exchange as a proxy for the extent of investors' risk aversion as well as the "Ted spread," which is the difference between the 3-month Eurodollar Deposit Rate in London (LIBOR) and the 3-month U.S. Treasury Bill yield. The latter measure gauges the general level of stress in the money market for financial institutions.

We apply the Ordinary Least Squares (OLS) method to do the estimation for each of the sample countries for the five links and for about 100 countries, which include advanced economies (IDC), less developed countries (LDC), and emerging market countries (EMG) the latter of which is a subset of LDC. ${ }^{10}$ Inevitably, the sample size varies depending on data availability. The sample period is 1986 through 2015, using monthly data, with regressions implemented over non-overlapping three year periods. ${ }^{11}$ That means that we obtain time-varying

\footnotetext{
${ }^{8}$ This is true especially after the ECB and the Bank of Japan lowered their policy rates down to zero but before they adopted negative interest rates.

${ }^{9}$ Whenever we include a variable for the policy interest rate, whether as a level or a change, in $X^{C}$ (such as the estimations for Links 1 and 2), we do not include the first component of U.S. FRB, ECB, and Bank of Japan's interest rates as part of the global factor vector to avoid redundancy with $X^{C}$. We also use the first principal component of oil and commodity prices - to avoid multicollinearity or redundancy - as a control variable for input or commodity prices.

${ }^{10}$ The emerging market countries (EMG) are defined as the countries classified as either emerging or frontier during the period of 1980-1997 by the International Financial Corporation plus Hong Kong and Singapore.

${ }^{11}$ The starting date for the sample period is chosen mainly based on data availability for the second-step estimation. Conceptually, the mid-1980s is also the time when global spillover effects became more evident after financial integration started taking place first among advanced economies then among less developed countries.
} 
$\hat{\gamma}_{F i t}^{C}$ across the panels. For all the estimations, we exclude the U.S. and Japan. As for the Euro member countries, they are removed from the sample after the introduction of the euro in January 1999 or they become member countries, whichever comes first. ${ }^{12}$

\subsection{The Second Step: Baseline Model}

Once we estimate $\gamma_{F i t}^{C}$ for each of the dependent variables, we regress $\hat{\gamma}_{F i t}^{C}$ on a number of country-specific variables. To account for potential outliers on the dependent variable, we apply the robust regression estimation technique to the following estimation model. ${ }^{13}$

$$
\hat{\gamma}_{F i t}^{C}=\theta_{0}+\theta_{1} \text { OMP }_{F i t}+\theta_{2} M C_{F i t}+\theta_{3} L_{I N K_{F i t}}+\theta_{4} I N S T_{F i t}+\theta_{5} C R I S I S_{F i t}+u_{F i t}
$$

Here, the choice of variables is based on a wide variety of literature pertaining to spillover effects and global synchronization of financial or macroeconomic variables. Hence, we assume that the above estimation model takes a reduced form, rather than a structural form, by which we can address various theoretical predictions at once, rather than relying on one particular theory.

There are four groups of explanatory variables. The first group of explanatory variables is a set of open macroeconomic policy choices $\left(O M P_{i}\right)$, for which we include the indexes for exchange rate stability $(E R S)$ and financial openness $(K A O P E N)$ from the trilemma indexes by Aizenman, et al. (2013). As another variable potentially closely related to the trilemma framework, we include the variable for IR holding (excluding gold) as a share of GDP because we believe the level of IR holding may affect the extent of cross-country financial linkages. ${ }^{14}$

The group $M C_{i}$ includes macroeconomic conditions such as inflation volatility, current account balance, and public finance conditions. As the measure of public finance conditions, we include gross national debt expressed as a share of GDP.

\footnotetext{
${ }^{12}$ Endogeneity can be an issue for this type of estimation. As a robustness check, we re-estimated the first-step model by lagging the right-hand-side variables. However, it did not change the characteristics of the results (not reported). Hence, we keep the estimation method as it is.

13 This estimation method keeps recursively down-weighting the outliers until it obtains converged estimates.

${ }^{14}$ Aizenman, et al. (2010, 2011) show the macroeconomic impact of trilemma policy configurations depends upon the level of IR holding.
} 
In addition, we include variables that reflect the extent of linkages with the center countries $(L I N K)$. One linkage variable is meant to capture real, trade linkage, which we measure as: $T R_{-} L I N K_{i p}=I M P_{i p}^{C} / G D P_{i p}$ where $I M P_{i}^{C}$ is total imports into center economy $C$ from country $i$, that is normalized by country $i$ 's GDP. Another linkage variable is financial linkage, FIN_LINK $i p$. We measure it with the ratio of the total FDI stock and bank lending from country $C$ in country $i$ both as shares of country $i$ 's GDP.

Another variable that also reflects the linkage with the major economies is the variable for the extent of trade competition (Trade_Comp). Trade_Comp measures the importance to country $i$ of export competition in the third markets between country $i$ and major country $C$. Shocks to country $C$, and especially shocks to country $C$ that affects country $c$ 's exchange rate, could affect the relative price of country $C$ 's exports and therefore affect country $i$ through trade competition in third markets. See Appendix for the variable construction. A higher value of this measure indicates country $i$ and major economic $C$ exports products in similar sectors so that their exported products tend to be competitive to each other.

The fourth group is composed of the variables that characterize the nature of institutional development (INST), namely, variables for financial development and legal development. For the measure of the level of financial development, we use the first principal component of financial development using the data on private credit creation, stock market capitalization, stock market total value, and private bond market capitalization all as shares of GDP. Likewise, we measure the level of legal development using the first principal component of law and order $(L A O)$, bureaucratic quality $(B Q)$, and anti-corruption measures (CORRUPT). Higher values of these variables indicate better conditions.

To control for economic or financial disruptions, we include a vector of currency and banking crises (CRISIS). For currency crisis, we use a dummy variable based on the exchange market pressure (EMP) index which is calculated using the exchange rate against the currency of the base country. The banking crisis dummy is based on the papers by Laeven and Valencia (2008, 2010, 2012).

The variables in $M C$ and INST are included in the estimations as deviations from the U.S., Japanese, and Euro Area's counterparts. The variables in vectors $O M P, M C$, and INST are sampled from the first year of each three year panels to minimize the effect of potential 
endogeneity or bidirectional causality. ${ }^{15}$ Also, in order to capture global common shocks, we also include time fixed effects.

\section{Empirical Results for the Baseline Estimation}

\subsection{First-Step Estimations - Connectivity with the CEs}

As the first step, we estimate the extent of correlation for each of the five financial linkages while controlling for two kinds of global factors: "real global" and "financial global," using the three-year, non-overlapping panels in the 1986-2015 period.

To gain a birds-eye view of the empirical results and the general trend of the groups of factors that influence the financial links, we focus on the joint significance of the variables included in the real global and financial global groups, and vector $X^{C}$ the latter of which includes the financial variables of the CEs for each of the five potential financial links (Table 1 and Figure 1).

Figure 2 illustrates the proportion of countries for which the joint significance tests are found to be statistically significant (with the $p$-value less than 5\%) for the real global and financial global groups, and vector $X^{C}$ for the five financial links. While we present the proportion for the groups of advanced economies (IDC) and less developed economies (LDC) after 1992, our discussions focuses on the results of developing countries. ${ }^{16}$

The graphical depictions in Figure 2 lead to the following conclusions. First, the influence of the CEs is the greatest for the policy interest rates and the real effective exchange rates. That is, the policy interest rates and the REER of the CEs affect most joint-significantly those of the PHs, respectively. This is consistent with the findings reported in Aizenman et al. (2016).

Second, the REER of the CEs significantly affects the stock market price changes of the PHs during and after the GFC of 2008, though the impact dwindles toward the end of the sample period. This and previous findings are consistent with the reactions expressed by emerging

\footnotetext{
${ }^{15}$ Sampling data from the first year of each three-year panel could still entail bidirectional causality. As another way of mitigating endogeneity or bidirectional causality, we could lag the right-hand-side variables, but by one threeyear panel. Lagging the right-hand-side variables this way could mean that we assume it takes three to five years for the right-hand-side variables to affect the dependent variable, which we do not think is plausible.

${ }^{16} \mathrm{We}$ also conduct the same exercise for the subgroup of EMGs. The figures for the EMG group are usually qualitatively similar to those of the LDC group. Hence, we omit discussing them here.
} 
market policy makers - especially those in "Fragile Five" - to the taper in Fed quantitative easing and the Federal Fund rate increase in December 2015.

Third, the policy interest rates of the CEs do not affect the REER of many PHs. Even during the GFC and its immediate aftermath, the proportion of the countries for which the policy interest rates of the CEs are jointly significant is about $20 \%$. A similar observation can be made for the REER-EMP link.

Fourth, as far as the policy interest rate link between the CEs and the PHs (Link 1) is concerned, the proportion of joint significance is also relatively high for the group of "financial global" variables during the GFC and the last three year panel for developing countries and since the GFC for developed countries and emerging market countries, suggesting global financial factors have been playing an important role in affecting the policy interest of countries regardless of income levels. This result is consistent with the Rey's (2013) thesis of "global financial cycles." Not surprisingly, economies are more exposed to global financial shocks during periods of financial turbulence while also following CEs' monetary policies.

Figure 3 disaggregates the effect of the CEs. The bars illustrate the proportion of the countries with significant $\hat{\gamma}$ 's for the three CEs: the United States, the euro area, and Japan. We see the U.S. financial variables exerting the most significant effects on the financial variables of the PHs for the policy interest rate link and the REER link in most of the time period, and for the REER-stock market price link during the GFC years. For the policy interest rate and the REER links, we see the euro area affecting the financial variables of the PHs as well.

\subsection{Results of the Second-Step Estimation}

Now, we investigate the determinants of the extent of linkages, $\hat{\gamma}_{F i t}^{C}$, using the estimation model based on equation (2). Table 2 reports the estimation results for the five linkages for the LDC and EMG samples. The bottom rows of the tables also report the joint significance tests for each vector of explanatory variables.

We begin by discussing the results for the open macro policy arrangements, namely, exchange rate stability, financial openness, and IR holding. While PHs with more open financial markets tend to follow the monetary policy of the CEs, the extent of exchange rate stability they pursue does not matter (columns 1 and 2). Aizenman et al. (2016) found a significantly positive 
estimate for the exchange rate variable, but our estimates are also positive but not statistically significant. ${ }^{17}$

The more stable a PH country's exchange rate movements are, the more sensitive its REER to the CEs' policy interest rates or REER (columns 3-6). These results make sense; PHs preferring more exchange rate stability follow the CEs' monetary policy or real appreciation of the CEs' currencies, which is what we have observed among emerging market economies in 2013-15.

Interestingly, higher levels of IR holding would make it easier for both developing and emerging market countries to follow the currency real appreciation of the CEs, though there is a possibility this correlation is capturing reverse causality. Also, not surprisingly, PHs with more open financial markets tend to guide their REER to follow that of the CEs, though the estimate is marginally significant. Such an observation cannot be made for the EMG group (columns 5 and $6)$.

When the CEs experience real appreciation, the more exchange rate stability a $\mathrm{PH}$ pursues, the less pressure it faces on its EMP (columns 7 and 8). At the same time, if the PH has more open financial markets, it would face less pressure on its EMP when the CEs' currencies are appreciating in real terms. The interpretation of this result is difficult; it could be that more open financial markets are associated with more developed financial markets, that are more robust to shocks emanating from abroad. Alternatively, countries that are subject to shocks tend to implement capital controls.

Open macro policies do not seem to matter for the link between the CEs' REER and the PHs' stock market price movements (columns 9 and 10). The F-test for the joint significance for the open macro variables is far from significant. Instead, the groups of macroeconomic conditions and institutional characteristics are found to be jointly significant. Interestingly, PHs with higher debt levels or higher levels of inflation volatility tend to have their stock market prices falling when the CEs experience currency real appreciation. We infer that weak macroeconomic conditions lead to capital flight once the CEs experience real appreciation, which in turn leads equity market declines. The negative estimate on the current account variable

\footnotetext{
${ }^{17}$ We do not include the growth rate of industrial production in the first-step estimation to maximize the sample size of the gammas. This, along with the extended sample period, may explain the different estimation results for the exchange rate stability index.
} 
indicates that while PHs running current account deficit tend to experience real depreciation when the CEs' currencies appreciate in real terms, weaker currencies of PHs could allow their firms to experience a rise in their income flows, pushing up the stock market prices in those economies.

\section{Impacts of Currency Weights and External Debt}

In addition to the baseline model, we investigate the impact of other factors, especially those which are related to the balance sheets of the countries. The first factor we investigate is the extent of belonging to the dollar or euro zone. Clearly, the United States was the epicenter of the GFC. That means that countries that are dollar-oriented or dollar centric in their trade of goods and services as well as financial assets must have been more exposed to shocks arising from the U.S. We can make a similar argument about the extent of belonging to the euro zone especially since the euro area experienced the debt crisis in the 2010s.

The other factor, closely linked with the previous factor, is how exposed countries are in terms of being indebted externally. Highly indebted countries can be more susceptible to external shocks, especially if the debt is denominated in foreign currencies. We also investigate the interactive effects of external debt exposure and the extent of reliance on the major currencies for debt denomination.

This is a timely question. For the last two decades, the extent of "original sin" - the inability of developing countries to issue debt in their domestic currencies in international markets - has been perceived to be declining. ${ }^{18}$ That stands in contrast to the situation during emerging market crises of the 1980s through early 2000's, when all external debt was essentially foreign currency denominated debt. In such cases, cross border asset-liability currency mismatches combined with large cross-border holdings meant that currency depreciations could easily cause liquidity crises.

\footnotetext{
${ }^{18}$ See Hausmann and Panizza (2011), who argue that the decline in the extent of original sin has been only anecdotal by showing that the decline in original sin has been modest if any. Ito and Rodriguez (2015) also show that the extent of reliance on foreign currency denomination for issuing international debt has not changed much for the last two decades.
} 


\subsection{Impacts of Currency Weights and Trade with Currency Zones}

\subsubsection{Model Framework}

We now investigate the impact of the extent of belonging to a major currency zone. When PHs' monetary policy makers make decisions, they almost inevitably incorporate the monetary policy of the issuer of a major currency which they reference to, or they refer to an implicit, or de facto, currency basket composed of several major currencies. Hence, once a shock arises in a CE, reactions by the PHs could be affected by the composition of the major currencies in the currency basket. That is, the degree of sensitivity among the PHs to the policies and economic conditions of the CEs can depend upon the weights of the currencies in the basket. In the analysis below, when, say, the dollar has the highest weight in the basket, we regard the economy of concern as dollar-oriented or belonging to the dollar zone. The currency weights can be independent of the degree of exchange rate stability a country pursues.

Using the widely-used method developed by Haldane and Hall (1991) and popularized by Frankel and Wei (1996), we estimate the weights of the dollar, the euro (or the German deutsche mark and the French franc before the introduction of the euro in 1999), the yen, and the British sterling with a rolling window of 36 months. ${ }^{19}$

With the estimated weights, we can test whether and to what extent the weights of currencies in the basket affect the extent of connectivity between the CEs and the PHs (i.e., $\hat{\gamma}$ 's ) using the following model:

$$
\begin{aligned}
& \hat{\gamma}_{F i t}^{C}=\theta_{0}+\theta_{1} O M P_{F i t}+\theta_{2} M C_{F i t}+\theta_{3} L_{I N K_{F i t}}+\theta_{4} I N S T_{F i t}+\theta_{5} \text { CRISIS }_{F i t} \\
& +\theta_{6} C Z W_{\text {Fit }}^{\text {US,Euro }}+\theta_{7}\left(D \Gamma_{\text {Fit }}^{\text {US,Euro }} \times C Z W_{\text {Fit }}^{\text {US, Euro }}\right)+u_{\text {Fit }} \text {, }
\end{aligned}
$$

where $C$ refers to the CEs: the U.S., the Euro area, and Japan and $F$ to the five financial linkages. $C Z W^{U S, \text { Euro }}$ is the estimated weights for the dollar and the euro. $D \Gamma$ represents the dummies for $\gamma^{U S}$ and $\gamma^{\text {Euro }}{ }^{20}$

\footnotetext{
${ }^{19}$ The basic assumption of this exercise is that monetary authorities use an implicit or hypothetical basket of currencies as the portfolio of official foreign exchange reserves, but that the extent of response to the change in the value of the entire basket should vary over time and across countries. If the authorities want to maintain a certain level of exchange rate stability, whether against a single currency or a basket of several currencies, they should allow the currency value to adjust only in accordance with the change in the entire value of the basket of major currencies. The examples of the application of this method can be found in Frankel and Wei (1996) among many others.

${ }^{20}$ Keep in mind that we have $\gamma^{U S}, \gamma^{E u r o}$, and $\gamma^{J P}$ for country $i$ in year $t$ as the dependent variable.
} 
We focus on $\theta_{7}$, which includes the interaction term between the dummy for $\gamma^{U S}$ and the currency zone weight for the dollar $\left(C Z W^{U S}\right)$ and the one between the dummy for $\gamma^{E u r o}$ and the currency zone weight for the euro $\left(C Z W^{\text {Euro }}\right)$.

If the extent of belonging to a currency zone matters, $\hat{\theta}_{7}$ must be statistically significant. Because we have the two dummies for $\gamma^{U S}$ and $\gamma^{\text {Euro }}$, the sensitivity to a shock in Japan is treated as the baseline. Hence, $\theta_{6}$ represents how the dollar or euro currency weight affects the degree of sensitivity to a shock originating in Japan.

Hence, for example, if Korea has a high dollar zone weight, the degree of sensitivity to a financial shock arising from the U.S. $\left(\hat{\gamma}^{U S}\right)$ should be higher if the dollar zone weight $\left(C Z W^{U S}\right)$ is higher. Likewise, the impact of the euro weight can be found in $\theta_{7}$. Also, the dollar or euro zone weight $\left(C Z W^{U S \text { or Euro }}\right)$ should matter less to the shocks occurring in Japan $\left(\theta_{6}\right){ }^{21}$

One merit of having estimated currency weights for our sample countries is that, using the estimated currency weights, we can divide the currency zones' partners of each non-major currency economy into five currency zones. ${ }^{22}$ To do so, every non-G5 economy is divided into G5-currency zones, based on the estimated G5-currency weights, i.e., $\hat{\beta}_{i h t}$, for the economy. For example, if Thailand has a currency basket, with the USD weight of $a \%$, the DM weight of $b \%$, the FF weight of $c \%$, the BP weight of $d \%$, and the yen weight of $e \%$, then we assume that $a \%$ of Thailand's economy belongs to the USD zone, $b \%$ to the DM zone, $c \%$ to the FF zone, $d \%$ to the UKP zone, and $e \%$ to the yen zone. All other non-G5 economies are similarly divided into G5 currency zones. On the other hand, each of the G5 countries is assumed to constitute its own currency zone. Then, the trade share of a non-G5 economy (say India) with countries belonging to a major-currency zone can be calculated first by multiplying $\hat{\beta}_{i h t}$ with bilateral trade with each partner (say Thailand, while bilateral trade between India and Thailand is defined as the sum of bilateral exports and imports), and then by summing up all the products over all the bilateral

\footnotetext{
${ }^{21}$ That means $\boldsymbol{\theta}_{6}$ should have the opposite sign to $\boldsymbol{\theta}_{7}$ or be insignificant.

22 The choice of the G5 countries is based on the currencies represented by the SDR basket during the sample period, see https://www.imf.org/external/np/fin/data/rms_sdrv.aspx.
} 
trade pairs. The ratio of this sum to the economy's (India's) total trade is regarded as its trade share with one of the "major-currency zones." 23

Now, we include the share of trade with respect to the dollar and the euro zones instead of the dollar and the euro zone weights as follows:

$$
\begin{aligned}
\hat{\gamma}_{F i t}^{C}=\theta_{0}+\theta_{1} O M P_{F i t} & +\theta_{2} M C_{F i t}+\theta_{3} \text { LINK }_{F i t}+\theta_{4} I_{N S T_{F i t}}+\theta_{5} C R I S I S_{F i t} \\
& +\theta_{6} T H_{-} C Z_{F i t}^{U S, \text { Euro }}+\theta_{7}\left(D \Gamma_{F i t}^{U S, \text { Euro }} \times T H_{-} C Z_{F i t}^{U S, E u r o}\right)+u_{F i t} .
\end{aligned}
$$

Like in the previous case, if the shares of trade with countries in the dollar zone or those in the euro zone matter, $\widehat{\theta_{7}}$ should be statistically significant, and $\widehat{\theta}_{6}$ would capture the impact of trade with the dollar or euro zone countries on the sensitivity to a financial shock arising from Japan. $^{24}$

\subsubsection{Estimation Results}

Table 3 reports the results for each of the five link regressions. To conserve space, we only report the estimates for the open macro variables and the variables pertaining to currency weights.

Although the extent of belonging to the dollar zone does not matter for the link between the CEs' policy interest rates and the PHs' REER (Link 2), it does matter for the link between the CEs' REER and the PHs' REER (Link 3). If the U.S. experiences a positive (i.e., appreciation) shock to its REER, developing countries with higher USD weights tend to experience REER appreciation, which also applies to the EMGs. The euro weights are always positive factors for both subgroups. We can also see for both subgroups, the variable for exchange rate stability is found to be a significantly positive factor. With these results, we see that both developing and emerging market countries with higher weights of major currencies in their baskets tend to have the "fear of floating." These countries are also affected by greater financial openness and IR holding as well.

${ }^{23}$ For country $i$, the currency zone share for major currency $h$ is $S H A R E_{-} h_{i t}=\frac{\sum_{j}^{J} \beta_{i h t} \cdot T R A D E_{i j t}}{T R A D E_{i t}}$ where $j$ is $i$ 's trading $\operatorname{partner}(j \in J)$ and $\sum_{h}^{H} S H A R E_{-} h_{i t}=1$.

${ }^{24}$ To avoid redundancy, the variable for trade demand by the CEs is removed. 
U.S. REER appreciation would lead to an increase in EMP (Link 4) for both LDCs and EMGs if they have higher dollar zone weights, and more euro-oriented economies tend to have smaller or more negative impacts.

U.S. REER appreciation would cause declines in stock markets in LDCs and EMGs if their dollar zone weights are higher (Link 5), suggesting that U.S. REER appreciation may cause capital flight from dollar-oriented countries.

When we include the share of trade with respect to the dollar and the euro zones, generally, the estimation results for these variables remain intact qualitatively but usually with stronger statistical significance. Obtaining essentially consistent results indicate that both currency weights and the share of trade with the dollar and euro zones matter for the extent of spillover linkages to the CEs.

\subsection{Impacts of External Debt}

We shift our attention to the impact of other balance sheet factors on the extent of susceptibility to shocks occurring in the CEs. In particular, external debt is our focus since it has long argued that it increases the level of risk exposure.

We examine the impacts of the following variables.

- External debt as a share of exports

- External debt as a share of GNI

- Short-term debt as a share of exports

- Short-term debt as a share of total external debt

- $\quad$ Short-term debt as a share of IR

We report the results for the five links' estimations in Table 4. The results for Link 1: policy interest rate link between the CEs and the PHs show that this link is not affected by how much PHs owe externally. The estimate for the size of (outstanding) international debt securities is positive, but it is not statistically significant.

However, the link between the CEs' policy interest rates and PHs' REER (Link 2) is affected by the size of external debt. The estimate for international debt (as a share of GNI) and the one for external debt (as a share of exports) are significantly negative for the EMG countries. 
The results indicate that, for example, a rise in the U.S. policy interest rate would lead more toward currency real depreciation of a $\mathrm{PH}$ if its total external debt is larger.

Such a negative impact of external debt is also observed when we focus on the REER link between the CEs and the PHs (Link 3). The estimate on the variable for external debt (as a share of GNI) is significantly negative among the EMGs. For the LDC group, not just external debt (as a share of GNI) but also short-term debt (as a share of exports) are found to be negative contributors to the REER link. These findings suggest that developing or emerging market countries would find it harder to pursue exchange rate stability against the CEs' currencies when they are loaded with external debt.

Greater levels of external debt or short-term debt would also make PHs' EMP more positively correlated with CE's REER especially among emerging market countries (Link 4). These results suggest that if the CEs experience real currency appreciation, that would draw capital flows from emerging market countries, thereby creating upward pressure on the EMP, explaining why emerging market crises often unhappy when the CEs -- particularly the U.S. -implement contractionary monetary policy.

The link between the CEs' REER change and the PHs' stock market price changes become more negative when the PHs are more indebted short-term. Consistent with the previous case, CEs' real currency appreciation would cause capital outflows from emerging market countries, which would cause their stock market prices to fall. Again, being indebted short-term increases the risk of negative spillover effects from the CEs.

\subsection{Impacts of Currency Composition of Debt}

We turn now examining how the composition of external debt, holding constant the level of debt, affects the linkages. For instance, if a peripheral economy has more dollar-denominated debt, such an economy should be more vulnerable to spillover effects from the U.S., more so than to spillovers from other CEs. Hence, the currency composition of the debt is important.

As has been widely evidenced, many economies are reliant on the dollar or other hard currencies to issue international debt. However, such reliance would entail intrinsic instability because currency depreciation would increase the debt burden in terms of the domestic currency and cause currency mismatch. If a peripheral country issues a large portion of its international 
debt in the dollar while pegging its currency to the dollar, expected depreciation would cause a self-fulfilling twin (i.e., currency and debt) crisis.

Hence, we take a look at the impact of currency compositions in international debt denomination, focusing the share of dollar-denominated debt. For that, we use the following specification.

$$
\begin{aligned}
\hat{\gamma}_{F i t}^{C}=\theta_{0}+\theta_{1} O M P_{F i t} & +\theta_{2} M C_{F i t}+\theta_{3} L_{I N K_{F i t}}+\theta_{4} I N S T_{F i t}+\theta_{5} C_{R I S I S} \\
& +\theta_{6} C S H_{F i t}^{U S}+\theta_{7}\left(D \Gamma_{F i t}^{U S} \times C S H_{F i t}^{U S}\right)+u_{F i t},
\end{aligned}
$$

where $C S H^{U S}$ is the share of the dollar in a certain variable for debt, namely, either public and publicly guaranteed debt or international debt securities. More specifically, we test the following six variables for the share of the dollar in debt denomination:

- Dollar-denominated International debt $(\%)=$ share of the dollar-denomination in total international debt securities, Extracted from the Bank for International Settlements (BIS) Debt Securities Statistics.

- $\quad$ Public debt denominated in the dollar $(\%)=$ share of dollar-denominated external long-term public and publicly-guaranteed debt in total PPG. Extracted from the World Bank’s Global Development Indicators.

- Dollar-denominated International debt (\%) - financial Institution = share of the dollar-denomination in total international debt securities issued by financial institutions.

- Dollar-denominated International debt $(\%)-$ non-financial Institution $=$ share of the dollar-denomination in total international debt securities issued by non-financial corporations, BIS

- Dollar-denominated International debt $(\%)-$ government sector $=$ share of the dollar-denomination in total international debt securities issued by government sector, BIS

We include these variables as both individually and interactively with the dummy for the correlation with the U.S. $\left(\gamma^{U S}\right)$ as we did with the currency weights variables or the variables for 
the share of trade with the dollar and the euro. Likewise, the estimate of our focus is $\hat{\theta}_{7}$, which is supposed to capture whether and to what extent the share of the dollar in debt affects the spillover effects arising from the U.S. Since we only focus on the effect of the dollar, $\hat{\theta}_{6}$ would capture the effect on the share of the dollar in debt denomination on the spillover effects from the euro area or Japan.

We report the estimation results in Table 5. In the section for Link 1, the policy interest rate link, we see that for both the LDC and EMG groups, the estimated extent of linkage is weaker or more negative if the share of the dollar in international debt securities issued by financial institute is higher. This result is consistent with the result we obtained when examining the impact of the dollar weight. Considering that the dollar share in international debt and the dollar weight in the currency basket are correlated (McCauley and Chen, 2015; Ito, McCauley, and Chen, 2015), this finding is unsurprising.

The higher dollar share in international debt securities a PH has, the more positively correlated its REER to a policy interest rate change in the U.S. (Link 2). However, that applies only to the dollar share in international debt securities issued by the government sector of the $\mathrm{PH}$, and the estimates are not statistically significant. One possible explanation is that the $\mathrm{PH}$ would fear fluctuations in its exchange rate against the dollar if it has more government debt denominated in the dollar ("fear of floating").

Such fear of floating is more clearly evidenced in the REER-REER link (Link 3), whether the debt is issued by financial institution, non-financial institution, or government sector. The estimates of the interactions terms between the U.S. gamma and the dollar share in the three types of international debt are all significantly positive for the LDC sample. Simply, if PH's international debt is more denominated in the dollar, the PH would try to align its REER with that of the U.S. In fact, it is not just for international debt securities, the dollar share in public and publicly guaranteed debt also makes the PH's REER more sensitive to the U.S. REER.

Given the above result for Link 3, it is not surprising that we also find similar results for the link between PHs' EMP and the U.S. REER (Link 4). If the U.S. experiences currency real appreciation, the PHs' EMP would be more responsive if the dollar share is higher in the denomination for international debt issued by either financial or non-financial institutions, or for public and publicly guaranteed debt. 
PHs with more dollar-denominated international debt or public debt also tend to respond to a change in the U.S. REER more negatively (Link 5). As it happened at the time of the "taper tantrum," a rise in the U.S. REER leads to stock market price declines among the PHs with dollar-denominated international debt or public debt.

\section{Concluding Remarks}

Since the U.S. started winding down its unconventional monetary policy in 2013, emerging market policymakers have anxiously awaited the direction of monetary policy conducted by advanced economy monetary authorities, especially the Fed. Such concerns intensified when the Fed terminated its zero interest rate policy in December 2015. In increasingly integrated global financial markets, connectivity between the center economies and the peripheral economies has become tighter, increasing the speed and intensity of transmission and spillover of monetary, financial and policy shocks. This environment has created more challenges for the policy makers in non-center economies, and indeed has prompted a re-think of the role of monetary policy and the trilemma hypothesis.

This paper investigates the questions of whether and how the financial conditions of developing and emerging market countries are affected by the movements of financial variables in the center economies (the U.S., Japan, and the Euro area). Our empirical method relies upon a two-step approach. We first investigate the extent of connectivity for the five linkages between a financial variable of the CEs and another (or the same) financial variable of the PHs while controlling for global and domestic factors. In the second step, we treat these estimated sensitivities as dependent variables, and relate them to a number of country-specific macroeconomic conditions or policies, real or financial linkages, and the levels of institutional development. Among these variables, we focus on the impact of balance sheet-related factors, namely, the weights of major currencies, external debt, and currency compositions of debt.

From the first-step estimation, we find that for both policy interest rates and the REER, the link with the CEs has been dominant for developing and emerging market economies in the last two decades. At the same time, the movements of policy interest rates are found to be more sensitive to global financial shocks around the time of the emerging markets' crises in the late 1990s and early 2000s, and since the time of the GFC of 2008. 
In the second-step estimation, we generally find evidence that the weights of major currencies, external debt, and currency compositions of debt affect the degree of connectivity. We summarize our findings in Table 6.

More specifically, having a higher weight of the dollar or the euro in the implicit currency basket would make the response of a financial variable such as REER and EMP in the PHs more sensitive to a change in key variables in the CEs such as policy interest rates and REER. Having more exposure to external debt would have similar impacts on the financial linkages between the CEs and the PHs. Lastly, we find that currency composition in international debt securities matter. Generally, those economies more reliant on the dollar for debt issuance tend to be more vulnerable to shocks occurring in the U.S. 


\section{References:}

Alfaro, Laura, Sebnem Kalemli-Ozcan and Vadym Volosovych, 2008. "Why Doesn't Capital Flow from Rich to Poor Countries? An Empirical Investigation," The Review of Economics and Statistics 90(2): 347-368.

Ahmed, S. and A. Zlate. 2013. "Capital Flows to Emerging Market Economies: A Brave New World?" Board of Governors of the Federal Reserve System International Finance Discussion Papers, \#1081. Washington, D.C.: Federal Reserve Board (June).

Aizenman, Joshua. 2013. "The impossible Trinity - from the Policy Trilemma to the Policy Quadrilemma," Global Journal of Economics, 2013, 02:01.

Aizenman, Joshua and Hiro Ito. 2016. "East Asian Economies and Financial Globalization in the Post-Crisis World" NBER Working Paper 22268 (May 2016).

Aizenman, Joshua and Hiro Ito. 2014. "Living with the Trilemma Constraint: Relative Trilemma Policy Divergence, Crises, and Output Losses for Developing Countries” Journal of International Money and Finance 49 p.28-51, (May). Also available as NBER Working Paper \#19448 (September 2013).

Aizenman, Joshua, Yin-Wong Cheung, and Hiro Ito. 2015. "International Reserves Before and After the Global Crisis: Is There No End to Hoarding?” Journal of International Money and Finance Volume 52 (April 2015), Pages 102-126.

Aizenman, Joshua, Menzie D. Chinn, and Hiro Ito. 2016. "Monetary Policy Spillovers and the Trilemma in the New Normal: Periphery Country Sensitivity to Core Country Conditions," Journal of International Money and Finance, Volume 68, November 2016, Pages 298-330. Also available as NBER Working Paper \#21128 (May 2015).

Aizenman, Joshua, Menzie D. Chinn, and Hiro Ito. 2013. Review of International Economics, 21(3), 447-458 (August).

Aizenman, Joshua, Menzie D. Chinn, and Hiro Ito. 2011. "Surfing the Waves of Globalization: Asia and Financial Globalization in the Context of the Trilemma," Journal of the Japanese and International Economies, vol. 25(3), p. 290 - 320 (September).

Aizenman, Joshua, Menzie D. Chinn, and Hiro Ito. 2010. “The Emerging Global Financial Architecture: Tracing and Evaluating New Patterns of the Trilemma Configuration," Journal of International Money and Finance 29 (2010) 615-641. 
Caballero, Ricardo, Emmanuel Farhi, and Pierre-Olivier Gourinchas. 2008. “An Equilibrium Model of 'Global Imbalances' and Low Interest Rates,' American Economic Review, 98(1) (March): 358-393.

Calvo, Guillermo A. and Carmen M. Reinhart. 2002. “Fear Of Floating,” Quarterly Journal of Economics, v107(2,May), 379-408.

Christensen, J. H. E., and Glenn D. Rudebusch. 2014. "Estimating Shadow-rate Term Structure Models with Near-zero Yields," Journal of Financial Econometrics 0, 1-34.

Christiansen, H. and C. Pigott. 1997. "Long-Term Interest Rates in Globalised Markets", OECD Economics Department Working Papers no 175.

Chinn, Menzie D. and Hiro Ito. 2007. "Current Account Balances, Financial Development and Institutions: Assaying the World 'Savings Glut'," Journal of International Money and Finance, Volume 26, Issue 4, p. 546-569 (June).

Eichengreen, Barry and Ricardo Hausmann. 1999. "Exchange Rates and Financial Fragility," Paper presented at the symposium New Challenges for Monetary Policy, August 26-28, Jackson Hole, WY.

Eichengreen, Barry, Andrew Rose and Charles Wyplosz. 1995. "Exchange Market Mayhem: The Antecedents and Aftermaths of Speculative Attacks", Economic Policy, 21, pp. 249-312, October.

Eichengreen, Barry, Andrew Rose and Charles Wyplosz. 1996. "Contagious Currency Crises: First Tests", Scandinavian Journal of Economics, 98(4), pp. 463-484.

Eichengreen, Barry, and Poonam Gupta, 2014, “Tapering Talk: The Impact of Expectations of Reduced Federal Reserve Security Purchases on Emerging Markets, mimeo (UC Berkeley: January).

Forbes, Kristin J. and Menzie D. Chinn. 2004. "A Decomposition of Global Linkages in Financial Markets over Time," The Review of Economics and Statistics, August, 86(3): $705-722$.

Forbes, K. J. and F. E. Warnock, 2012. Capital Flow Waves: Surges, Stops, Flight, and Retrenchment. Journal of International Economics, 88(2), 235-251.

Frankel, J. and S. J. Wei. 1996. "Yen Bloc or Dollar Bloc? Exchange Rate Policies in East Asian Economies." In T. Ito and A Krueger, eds., Macroeconomic Linkage: Savings, Exchange Rates, and Capital Flows, Chicago: University of Chicago Press, pp 295-329. 
Fratzscher, M. 2011. "Capital Flows, Push Versus Pull Factors and the Global Financial Crisis," NBER Working Paper 17357 (Cambridge: NBER).

Ghosh, A. R., J. Kim, M. Qureshi, and J. Zalduendo, 2012. Surges. IMF Working Paper $\mathrm{WP} / 12 / 22$.

Ghosh, Atish R., Jonathan David Ostry, and Mahvash Saeed Qureshi. 2014. "Exchange Rate Management and Crisis Susceptibility: A Reassessment,” IMF Working Papers 14/11, Washington, D.C.: International Monetary Fund.

Ghosh, Atish R., Jonathan D Ostry, and Mahvash S Qureshi. 2015. "Exchange Rate Management and Crisis Susceptibility: A Reassessment," IMF Economic Review, Palgrave Macmillan, vol. 63(1), pages 238-276, May.

Haldane, A. and S. Hall. 1991. "Sterling's Relationship with the Dollar and the Deutschemark: 1976-89.” Economic Journal, 101:406 (May).

Hausmann, R. and Panizza, U., 2011. "Redemption or abstinence? original sin, currency mismatches and counter cyclical policies in the new millennium," Journal of Globalization and Development, 2(1).

Huang, Y., X. Wang, and N. Lin. 2013. "Financial Reform in China: Progresses and Challenges," In Patrick, H. and Y. C. Park, eds. The Ongoing Financial Development of China, Japan, and Korea, Columbia University Press, New York: Columbia University. Hung, J. H. 2009. “China's Approach to Capital Flows since 1978” In Y.W. Cheung and K. Wang, ed. China and Asia: Economic and Financial Interactions, Routledge Studies in the Modern World Economy.

Ito, H. and M. Kawai. 2012. "New Measures of the Trilemma Hypothesis and Their Implications for Asia.” ADBI Working Paper 381. (February 2012).

Ito, H. and C. Rodriguez. 2015. "Clamoring for Greenbacks: Explaining the Resurgence of the US Dollar in International Debt.” RIETI Working Paper 15-E-119 (October).

Ito, H., and R. McCauley. 2016. "Re-scaling Global Imbalances: Key Currency Zones and Renminbi Management.” BIS Working Paper.

Laeven, L. and F. Valencia. 2010. "Resolution of Banking Crises: The Good, the Bad, and the Ugly,” IMF Working Paper No. 10/44. Washington, D.C.: International Monetary Fund. Laeven, L. and F. Valencia. 2012. "Systematic Banking Crises: A New Database," IMF Working Paper WP/12/163, Washington, D.C.: International Monetary Fund. 
Laeven, L. and F. Valencia. 2008. “Systematic Banking Crises: A New Database,” IMF Working Paper WP/08/224, Washington, D.C.: International Monetary Fund.

Mundell, R.A. 1963. Capital Mobility and Stabilization Policy under Fixed and Flexible Exchange Rates. Canadian Journal of Economic and Political Science. 29(4): 475-85.

Obstfeld, M. 2014. “Trilemmas and Tradeoffs: Living with Financial Globalization”, mimeo, University of California, Berkeley.

Obstfeld, M., J. C. Shambaugh, and A. M. Taylor. 2005. "The Trilemma in History: Tradeoffs among Exchange Rates, Monetary Policies, and Capital Mobility." Review of Economics and Statistics 87 (August): 423-438.

Rey, H. 2013. "Dilemma not Trilemma: The Global Financial Cycle and Monetary Policy Independence," prepared for the 2013 Jackson Hole Meeting.

Saxena, Sweta C. 2008. "Capital Flows, Exchange Rate Regime and Monetary Policy,” BIS Papers No 35. Basle: Bank for International Settlements.

Shambaugh, J. C., 2004. The Effects of Fixed Exchange Rates on Monetary Policy. Quarterly Journal of Economics 119 (1), 301-52.

Wu, Jing Cynthia and Fan Dora Xia. 2014. "Measuring the Macroeconomic Impact of Monetary Policy at the Zero Lower Bound”, NBER Working Paper No. 20117. 


\section{Appendix: Data Descriptions and Sources}

Policy short-term interest rate - money market rates Extracted from the IMF's International Financial Statistics (IFS).

Stock market prices - stock market price indices from the IFS

Sovereign bond spread - the difference between the long-term interest rate (usually 10 year government bond) and the policy short-term interest rate - i.e., the slope of the yield curve, IFS.

Real effective exchange rate (REER) - REER index from the IFS. An increase indicates appreciation.

Global interest rate - the first principal component of U.S. FRB, ECB, and Bank of Japan's policy interest rates.

Commodity prices - the first principal component of oil prices and commodity prices, both from the IFS.

VIX index - It is available in http://www.cboe.com/micro/VIX/vixintro.aspX and measures the implied volatility of S\&P 500 index options.

"Ted spread" - It is the difference between the 3-month Eurodollar Deposit Rate in London (LIBOR) and the 3-month U.S. Treasury Bill yield.

Industrial production - It is based on the industrial production index from the IFS.

Exchange rate stability (ERS) and financial openness (KAOPEN) indexes - From the trilemma indexes by Aizenman, et al. (2013).

International reserves - international reserves minus gold divided by nominal GDP. The data are extracted from the IFS.

Gross national debt and general budget balance - both are included as shares of GDP and obtained from the World Economic Outlook (WEO) database.

Trade demand by the CEs - TR_LINK ${ }_{i p}=I M P_{i p}^{C} / G D P_{i p}$ where ${ }_{I M P_{i}^{C}}$ is total imports into center economy $C$ from country $i$, that is normalized by country $i$ 's GDP based on the data from the IMF Direction of Trade database.

FDI provided by the CEs - It is the ratio of the total stock of foreign direct investment from country $C$ in country $i$ as a share of country $i$ 's GDP. We use the OECD International Direct Investment database.

Bank lending provided by the CEs - It is the ratio of the total bank lending provided by each of the CEs to country $i$ shown as a share of country $i$ 's GDP. We use the BIS database.

Trade competition - It is constructed as follows.

$$
\text { Trade_Comp } p_{i}^{C}=\frac{100}{M a x(\text { Trade_Comp })} \sum_{k}\left[\frac{\operatorname{Exp}_{W, k}^{C}}{\operatorname{Exp}_{W, k}^{W}} * \frac{\operatorname{Exp}_{W, k}^{i}}{G D P_{i}}\right]
$$

$\operatorname{Exp}_{W, k}^{C}$ is exports from large-country $c$ to every other country in the world $(W)$ in industrial sector $k$ whereas $E x p_{W, k}^{W}$ is exports from every country in the world to every other country in the world (i.e. total global exports) in industrial sector $k$. $E x p_{W, k}^{i}$ is exports from country $i$ to every other country in the world in industrial sector $k$, and $G D P_{i}$ is GDP for country $i$. We 
assume merchandise exports are composed of five industrial sectors $(K)$, that is, manufacturing, agricultural products, metals, fuel, and food.

This index is normalized using the maximum value of the product in parentheses for every country pair in the sample. Thus, it ranges between zero and one. ${ }^{25} \mathrm{~A}$ higher value of this variable means that country $i$ 's has more comparable trade structure to the center economies.

Financial development - It is the first principal component of private credit creation, stock market capitalization, stock market total value, and private bond market capitalization all as shares of GDP. ${ }^{26}$

Legal development - It is the first principal component of law and order ( $L A O)$, bureaucratic quality $(B Q)$, and anti-corruption measures (CORRUPT), all from the ICRG database. Higher values of these variables indicate better conditions.

Currency crisis - It is from Aizenman and Ito (2014) who use the exchange market pressure (EMP) index using the exchange rate against the currency of the base country. We use two standard deviations of the EMP as the threshold to identify a currency crisis.

Banking crisis - It is from Aizenman and Ito (2014) who follow the methodology of Laeven and Valencia (2008, 2010, 2012). For more details, see Appendix 1 of Aizenman and Ito (2014).

Exchange market pressure (EMP) index -It is defined as a weighted average of monthly changes in the nominal exchange rate, the international reserve loss in percentage, and the nominal interest rate. The nominal exchange rate is calculated against the base country that we use to construct the trilemma indexes (see Aizenman, et al., 2008). The weights are inversely related to each country's standard deviations of each of the changes in the three components over the sample countries.

$$
\begin{aligned}
& E M P_{i, t}=\alpha\left(\% \Delta e_{i, t}\right)+\beta\left[\Delta\left(i_{i, t}-i_{b, t}\right)-\gamma\left(\% \Delta r_{i, t}-\% \Delta r_{b}\right)\right.
\end{aligned}
$$

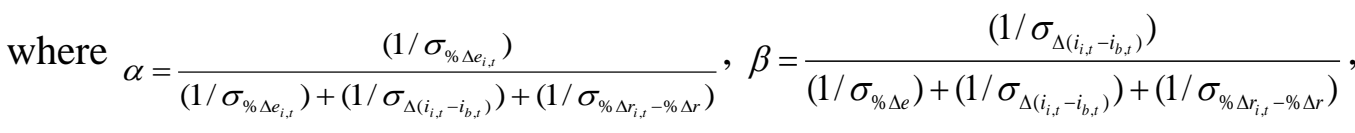

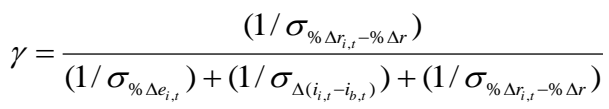

$b$ stands for the "base country," which is defined as the country that a home country's monetary policy is most closely linked with as in Shambaugh (2004) and Aizenman, et al. (2013). The base countries are Australia, Belgium, France, Germany, India, Malaysia, South Africa, the U.K., and the U.S. The base country can change as it has happened to Ireland, for example. Its base country was the U.K. until the mid-1970s, and changed to Germany since Ireland joined the European Monetary System (EMS).

To construct the crisis dummies in three-year panels, we assign the value of one if a crisis occurs in any year within the three-year period.

Share of export/import - The share of country i's export to, or import from, a major currency country (e.g., Japan) in country $i$ 's total export or import. The data are taken from the IMF's Direction of Trade.

\footnotetext{
25 This variable is an aggregated version of the trade competitiveness variable in Forbes and Chinn (2004). Their index is based on more disaggregated 14 industrial sectors.

${ }^{26}$ Because the private bond market capitalization data go back only to 1990, the FD series before 1990 are extrapolated using the principal component of private credit creation, stock market capitalization, and stock market total values, which goes back to 1976. These two FD measures are highly correlated with each other.
} 
Commodity export/import as a percentage of total export/import - Data are taken from the World Bank's World Development Indicators and the IMF's International Financial Statistics.

Currency weights $(C Z W)$ - First, we run the following estimation model:

$$
\Delta e_{i t}^{U S D}=\alpha_{i}+\beta_{i J Y t} \Delta e_{i t}^{J Y}+\beta_{i B P t} \Delta e_{i t}^{U K P}+\beta_{i D M t} \Delta e_{i t}^{D M}+\beta_{i F F t} \Delta e_{i t}^{F F}+\varepsilon_{i t} .
$$

Here, $e_{i t}$ is the nominal exchange rate of home currency $i$, against the dollar (USD), yen (JP), pound (UKP), Deutsche mark (DM), and French franc (FF). The major currencies in the right-hand side of the estimation equation can be thought of comprising an implicit currency basket in the mind of the home economy's policymaker. Therefore, $\hat{\beta}_{i h}$, the estimated coefficient on the rate of change in the exchange rate of major currency $h$ vis-à-vis the U.S. dollar, represents the weight of currency $h$ in the implicit basket. The weight of the dollar can be calculated as $\hat{\beta}_{i U S t}=1-\left(\hat{\beta}_{i J Y t}+\hat{\beta}_{i B P t}+\hat{\beta}_{i D M t}+\hat{\beta}_{i F F t}\right) .{ }^{27}$ We apply the estimation model to each of our sample currencies, but estimate it over rolling windows of 36 months. Hence, the coefficients $\hat{\beta}_{i h}$ 's are time-varying in monthly frequency to reflect the assumption that policymakers keep updating their information sets and, thus, currency weights. This rolling regression is not run for the G5 currencies, but their currency weights are set at the value of one, that is, each of the G5 countries is assumed to constitute its own currency zone without depending on other major-currency exchange rates. For the estimations, we use monthly data from the IMF's International Financial Statistics. Outliers observed for the estimated $\hat{\beta}_{i h t}$ due to financial or macroeconomic turbulences are deleted on a monthly basis. Any significantly negative $\hat{\beta}_{i h t}$ is assumed to be a missing estimate and a statistically insignificant negative $\hat{\beta}_{i h t}$ is replaced with a value of zero. Likewise, any $\hat{\beta}_{i h t}$ that is significantly no greater from the value of one is replaced with the value of one, while $\hat{\beta}_{i h t}$ significantly greater than one is replaced with a missing variable. Once outliers are removed and some estimates are replaced with other valued on a monthly basis, they are annually averaged to create annual data series.

Trade share with respect to each currency zone ( $T S H_{-}$CZ) - Using the estimated currency weights, we first divide the trade partners of each non-major currency economy into five currency zones. Each of major currency countries is assumed to constitute its own currency zone. Then, the trade share of a non-G5 economy (say India) with countries belonging to a major-currency zone can be calculated first by multiplying $\hat{\beta}_{\text {iht }}$ with bilateral trade with each partner (say Thailand, so bilateral trade between India and Thailand is defined as the sum of bilateral exports and imports), and then by summing up all the products over all the bilateral trade pairs. The ratio of this sum to the economy's (India's) total trade is regarded as its trade share with one of the "major-currency zones."

Foreign currency-denominated international debt (\% of GNI) - International debt securities denominated in any currency than the domestic currency (of the issuer), normalized by Gross National Income. The external debt data are extracted from the BIS International Debt

${ }^{27}$ If the home currency is pegged to the U.S. dollar (e.g., Hong Kong dollar), then $\hat{\beta}_{i U S t}=1$ and $\sum_{\substack{h=1 \\ h \neq U S}}^{H} \hat{\beta}_{\text {ih }}=0$. For an economy with its currency pegged to the DM, $\hat{\beta}_{i D M t}=1$. 
Security Database (IDSD), and GNI is from the World Bank's Global Development Indicators $(G D I)$.

External debt as a share of total exports; External debt as a share of GNI; Short-term debt as a ratio to total exports; Short-term debt as a ratio to total external debt; Short-term debt as a ratio to total IR holdings - All these data are extracted from the World Bank's Global Development Indicators.

Dollar-denominated international debt (\%) - International debt securities denominated in the US dollar as a share of total international debt securities. BIS-IDSD.

Public debt denominated in U.S. dollar (\%) - The share of external long-term public and publicly-guaranteed (PPG) debt contracted in the dollar in total long-term public and publicly-guaranteed debt. Data are from WDI.

Dollar-denominated international debt (\%): Financial institutions - The share of the dollardenominated international debt securities in total international debt securities issued by financial institutions, BIS-IDSD

Dollar-denominated international debt(\%): Non-financial institutions - The share of the dollardenominated international debt securities in total international debt securities issued by nonfinancial corporations, BIS-IDSD

Dollar-denominated international $\operatorname{debt}(\%)$ :Government sector - The share of the dollardenominated international debt securities in total international debt securities issued by gov't sector, BIS-IDSD 
Table 2: Factors Affecting the Five Links, 1989-2014

\begin{tabular}{|c|c|c|c|c|c|c|c|c|c|c|}
\hline & \multicolumn{2}{|c|}{$\begin{array}{c}\text { Link 1: ST-rate (CEs) } \rightarrow \\
\text { ST-rate (PHs) }\end{array}$} & \multicolumn{2}{|c|}{$\begin{array}{c}\text { Link 2:ST-rate (CEs) } \rightarrow \\
\text { REER (PHs) }\end{array}$} & \multicolumn{2}{|c|}{$\begin{array}{c}\text { Link 3: REER (CEs) } \rightarrow \\
\text { REER (PHs) }\end{array}$} & \multicolumn{2}{|c|}{$\begin{array}{c}\text { Link 4: REER (CEs) } \rightarrow \\
\operatorname{EMP}(\text { PHs })\end{array}$} & \multicolumn{2}{|c|}{$\begin{array}{c}\text { Link 5: REER (CEs) } \rightarrow \\
\text { Stock Market (PHs) }\end{array}$} \\
\hline & $\begin{array}{l}\text { LDC } \\
(1)\end{array}$ & $\begin{array}{c}\text { EMG } \\
(2)\end{array}$ & $\begin{array}{l}\text { LDC } \\
(3)\end{array}$ & $\begin{array}{c}\text { EMG } \\
(4)\end{array}$ & $\begin{array}{c}\text { LDC } \\
(5)\end{array}$ & $\begin{array}{c}\text { EMG } \\
(6)\end{array}$ & $\begin{array}{l}\text { LDC } \\
(7)\end{array}$ & $\begin{array}{c}\text { EMG } \\
(8)\end{array}$ & $\begin{array}{c}\text { LDC } \\
(9)\end{array}$ & $\begin{array}{c}\text { EMG } \\
(10)\end{array}$ \\
\hline Exch. Rate Stability & $\begin{array}{c}0.087 \\
(0.265)\end{array}$ & $\begin{array}{c}0.200 \\
(0.294)\end{array}$ & $\begin{array}{c}2.486 \\
(0.648) * * *\end{array}$ & $\begin{array}{c}2.990 \\
(0.748)^{* * *}\end{array}$ & $\begin{array}{c}0.779 \\
(0.072)^{* * *}\end{array}$ & $\begin{array}{c}0.862 \\
(0.087)^{* * *}\end{array}$ & $\begin{array}{c}-8.357 \\
(2.261)^{* * *}\end{array}$ & $\begin{array}{c}-7.307 \\
(2.735)^{* * *}\end{array}$ & $\begin{array}{c}0.246 \\
(0.254)\end{array}$ & $\begin{array}{c}0.394 \\
(0.316)\end{array}$ \\
\hline Financial Openness & $\begin{array}{c}0.461 \\
(0.228)^{* *}\end{array}$ & $\begin{array}{c}0.531 \\
(0.257)^{* *}\end{array}$ & $\begin{array}{c}0.282 \\
(0.546)\end{array}$ & $\begin{array}{c}0.648 \\
(0.657)\end{array}$ & $\begin{array}{c}0.093 \\
(0.060)\end{array}$ & $\begin{array}{l}-0.029 \\
(0.076)\end{array}$ & $\begin{array}{c}-4.564 \\
(1.833)^{* *}\end{array}$ & $\begin{array}{c}-4.810 \\
(2.280)^{* *}\end{array}$ & $\begin{array}{c}0.060 \\
(0.197)\end{array}$ & $\begin{array}{c}0.115 \\
(0.245)\end{array}$ \\
\hline IR Holding & $\begin{array}{l}-0.898 \\
(0.680)\end{array}$ & $\begin{array}{c}-0.788 \\
(0.833)\end{array}$ & $\begin{array}{l}-0.163 \\
(1.904)\end{array}$ & $\begin{array}{l}-0.252 \\
(2.205)\end{array}$ & $\begin{array}{c}0.806 \\
(0.210) * * *\end{array}$ & $\begin{array}{c}0.610 \\
(0.255)^{* *}\end{array}$ & $\begin{array}{c}0.912 \\
(5.904)\end{array}$ & $\begin{array}{c}2.192 \\
(7.793)\end{array}$ & $\begin{array}{l}-0.590 \\
(0.567)\end{array}$ & $\begin{array}{c}-1.252 \\
(0.801)\end{array}$ \\
\hline CA balance $(\%)$ & $\begin{array}{c}0.393 \\
(0.959)\end{array}$ & $\begin{array}{l}-0.539 \\
(1.238)\end{array}$ & $\begin{array}{l}-0.249 \\
(2.766)\end{array}$ & $\begin{array}{c}0.477 \\
(3.269)\end{array}$ & $\begin{array}{l}-0.165 \\
(0.306)\end{array}$ & $\begin{array}{c}0.020 \\
(0.378)\end{array}$ & $\begin{array}{c}-10.936 \\
(7.621)\end{array}$ & $\begin{array}{l}-10.536 \\
(11.044)\end{array}$ & $\begin{array}{c}-2.346 \\
(0.752)^{* * *}\end{array}$ & $\begin{array}{c}-2.312 \\
(1.196)^{*}\end{array}$ \\
\hline Gross debt $(\%)$ & $\begin{array}{c}0.177 \\
(0.121)\end{array}$ & $\begin{array}{c}0.200 \\
(0.126)\end{array}$ & $\begin{array}{c}0.110 \\
(0.334)\end{array}$ & $\begin{array}{c}0.668 \\
(0.379)^{*}\end{array}$ & $\begin{array}{l}-0.057 \\
(0.037)\end{array}$ & $\begin{array}{c}-0.103 \\
(0.044)^{* *}\end{array}$ & $\begin{array}{c}1.652 \\
(1.041)\end{array}$ & $\begin{array}{c}0.770 \\
(1.201)\end{array}$ & $\begin{array}{c}-0.232 \\
(0.110)^{* *}\end{array}$ & $\begin{array}{c}-0.272 \\
(0.127)^{* *}\end{array}$ \\
\hline Inflation Vol. & $\begin{array}{c}1.006 \\
(1.713)\end{array}$ & $\begin{array}{c}0.829 \\
(1.591)\end{array}$ & $\begin{array}{l}-2.111 \\
(3.677)\end{array}$ & $\begin{array}{c}-3.462 \\
(3.803)\end{array}$ & $\begin{array}{l}-0.191 \\
(0.406)\end{array}$ & $\begin{array}{l}-0.367 \\
(0.440)\end{array}$ & $\begin{array}{c}4.210 \\
(13.842)\end{array}$ & $\begin{array}{c}2.304 \\
(14.195)\end{array}$ & $\begin{array}{c}-7.381 \\
(2.772)^{* * *}\end{array}$ & $\begin{array}{c}-9.890 \\
(3.087)^{* * *}\end{array}$ \\
\hline Trade Comp. & $\begin{array}{l}-0.442 \\
(0.927)\end{array}$ & $\begin{array}{l}-0.527 \\
(1.005)\end{array}$ & $\begin{array}{l}-2.285 \\
(2.336)\end{array}$ & $\begin{array}{l}-3.033 \\
(2.645)\end{array}$ & $\begin{array}{c}-0.806 \\
(0.258)^{* * *}\end{array}$ & $\begin{array}{c}-0.556 \\
(0.306)^{*}\end{array}$ & $\begin{array}{c}13.508 \\
(7.630)^{*}\end{array}$ & $\begin{array}{c}3.740 \\
(9.036)\end{array}$ & $\begin{array}{l}-0.091 \\
(0.752)\end{array}$ & $\begin{array}{c}0.260 \\
(0.977)\end{array}$ \\
\hline Trade demand & $\begin{array}{c}1.627 \\
(1.117)\end{array}$ & $\begin{array}{c}1.728 \\
(1.146)\end{array}$ & $\begin{array}{c}2.373 \\
(2.420)\end{array}$ & $\begin{array}{c}2.943 \\
(2.652)\end{array}$ & $\begin{array}{c}1.294 \\
(0.267)^{* * *}\end{array}$ & $\begin{array}{c}1.490 \\
(0.307)^{* * *}\end{array}$ & $\begin{array}{c}0.896 \\
(8.967)\end{array}$ & $\begin{array}{c}3.277 \\
(9.756)\end{array}$ & $\begin{array}{l}-0.757 \\
(0.906)\end{array}$ & $\begin{array}{c}-0.494 \\
(1.033)\end{array}$ \\
\hline Bank Lending & $\begin{array}{l}-0.157 \\
(0.452)\end{array}$ & $\begin{array}{c}0.133 \\
(0.590)\end{array}$ & $\begin{array}{c}2.860 \\
(1.508)^{*}\end{array}$ & $\begin{array}{c}1.740 \\
(1.689)\end{array}$ & $\begin{array}{l}-0.090 \\
(0.167)\end{array}$ & $\begin{array}{c}-0.275 \\
(0.195)\end{array}$ & $\begin{array}{c}-15.949 \\
(5.000)^{* * *}\end{array}$ & $\begin{array}{c}-10.734 \\
(5.369)^{* *}\end{array}$ & $\begin{array}{c}-0.022 \\
(0.462)\end{array}$ & $\begin{array}{c}0.064 \\
(0.519)\end{array}$ \\
\hline Fin. Dev. & $\begin{array}{c}0.078 \\
(0.038)^{* *}\end{array}$ & $\begin{array}{c}0.071 \\
(0.040)^{*}\end{array}$ & $\begin{array}{c}-0.022 \\
(0.099)\end{array}$ & $\begin{array}{c}0.065 \\
(0.109)\end{array}$ & $\begin{array}{c}-0.059 \\
(0.011)^{* * *}\end{array}$ & $\begin{array}{c}-0.040 \\
(0.013)^{* * *}\end{array}$ & $\begin{array}{c}-0.389 \\
(0.336)\end{array}$ & $\begin{array}{l}-0.328 \\
(0.384)\end{array}$ & $\begin{array}{c}0.118 \\
(0.034)^{* * *}\end{array}$ & $\begin{array}{c}0.135 \\
(0.038)^{* * *}\end{array}$ \\
\hline Currency crisis & $\begin{array}{c}0.449 \\
(0.245)^{*}\end{array}$ & $\begin{array}{c}0.384 \\
(0.249)\end{array}$ & $\begin{array}{c}-1.582 \\
(0.589)^{* * *}\end{array}$ & $\begin{array}{c}-1.590 \\
(0.646)^{* *}\end{array}$ & $\begin{array}{c}-0.121 \\
(0.065)^{*}\end{array}$ & $\begin{array}{l}-0.099 \\
(0.075)\end{array}$ & $\begin{array}{c}3.523 \\
(2.018)^{*}\end{array}$ & $\begin{array}{c}0.931 \\
(2.198)\end{array}$ & $\begin{array}{c}0.091 \\
(0.199)\end{array}$ & $\begin{array}{c}0.117 \\
(0.226)\end{array}$ \\
\hline Banking crisis & $\begin{array}{c}-0.364 \\
(0.219)^{*}\end{array}$ & $\begin{array}{l}-0.358 \\
(0.238)\end{array}$ & $\begin{array}{c}1.276 \\
(0.480)^{* * *}\end{array}$ & $\begin{array}{c}0.909 \\
(0.575)\end{array}$ & $\begin{array}{l}-0.005 \\
(0.053)\end{array}$ & $\begin{array}{c}-0.113 \\
(0.067)^{*}\end{array}$ & $\begin{array}{c}2.551 \\
(1.764)\end{array}$ & $\begin{array}{c}3.020 \\
(2.159)\end{array}$ & $\begin{array}{c}-0.538 \\
(0.188)^{* * *}\end{array}$ & $\begin{array}{l}-0.344 \\
(0.230)\end{array}$ \\
\hline$N$ & 809 & 590 & 641 & 499 & 641 & 499 & 782 & 581 & 570 & 473 \\
\hline Adj. R2 & 0.01 & 0.02 & 0.03 & 0.05 & 0.27 & 0.27 & 0.06 & 0.04 & 0.12 & 0.13 \\
\hline \# of countries & 63 & 39 & 46 & 32 & 46 & 32 & 61 & 38 & 40 & 32 \\
\hline years & 1989-2014 & 1989-2014 & 1992-2014 & $1992-2014$ & $1992-2014$ & $1992-2014$ & $1989-2014$ & $1989-2014$ & $1992-2014$ & $1992-2014$ \\
\hline F-test, OMP & 0.16 & 0.18 & 0.00 & 0.00 & 0.00 & 0.00 & 0.00 & 0.01 & 0.63 & 0.35 \\
\hline F-test, Macro & 0.34 & 0.38 & 0.94 & 0.21 & 0.26 & 0.07 & 0.28 & 0.78 & 0.00 & 0.00 \\
\hline F-test, Ext. Link & 0.55 & 0.42 & 0.09 & 0.27 & 0.00 & 0.00 & 0.01 & 0.25 & 0.81 & 0.97 \\
\hline F-test, Inst. Dev. & 0.04 & 0.08 & 0.82 & 0.55 & 0.00 & 0.00 & 0.25 & 0.39 & 0.00 & 0.00 \\
\hline F-test, All & 0.04 & 0.03 & 0.00 & 0.00 & 0.00 & 0.00 & 0.00 & 0.00 & 0.00 & 0.00 \\
\hline
\end{tabular}

Notes: The estimations are conducted with the robust regression method due to the existence of outliers. * $p<0.1 ; * * p<0.05 ; * * * p<0.01$. The second estimation is conducted for the estimates $\hat{\gamma}_{F i}^{C}$ from the first-step estimation that does not include China as one of the center economies. Time fixed effects for the three-year panels and the constant are also included, though their estimates are not reported. 
Table 3: Effect of Currency Zones, 1989-2014

Link 1 -CEs: ST rate in the CEs $\rightarrow$ PHs: ST rate

\begin{tabular}{|c|c|c|c|c|c|c|c|c|c|}
\hline & $\begin{array}{l}\text { FULL } \\
\text { (1) }\end{array}$ & $\begin{array}{l}\text { FULL } \\
\text { (2) }\end{array}$ & $\begin{array}{l}\text { FULL } \\
\text { (3) }\end{array}$ & $\begin{array}{l}\mathrm{LDC} \\
(4)\end{array}$ & $\begin{array}{l}\mathrm{LDC} \\
(5)\end{array}$ & $\begin{array}{l}\mathrm{LDC} \\
(6)\end{array}$ & $\begin{array}{l}\text { EMG } \\
(7)\end{array}$ & $\begin{array}{c}\text { EMG } \\
(8)\end{array}$ & $\begin{array}{l}\text { EMG } \\
(9)\end{array}$ \\
\hline Exch. Rate Stability & $\begin{array}{l}0.091 \\
(0.202)\end{array}$ & $\begin{array}{l}0.087 \\
(0.202)\end{array}$ & $\begin{array}{l}0.075 \\
(0.205)\end{array}$ & $\begin{array}{c}0.094 \\
(0.257)\end{array}$ & $\begin{array}{l}0.079 \\
(0.258)\end{array}$ & $\begin{array}{l}0.046 \\
(0.262)\end{array}$ & $\begin{array}{l}0.141 \\
(0.278)\end{array}$ & $\begin{array}{l}0.144 \\
(0.282)\end{array}$ & $\begin{array}{l}0.176 \\
(0.287)\end{array}$ \\
\hline$\$$ zone weight $\left(\theta_{6}^{U S}\right)$ & $\begin{array}{l}0.111 \\
(0.161)\end{array}$ & & $\begin{array}{l}0.176 \\
(0.347)\end{array}$ & $\begin{array}{l}0.192 \\
(0.243)\end{array}$ & & $\begin{array}{l}0.773 \\
(0.820)\end{array}$ & $\begin{array}{l}0.105 \\
(0.257)\end{array}$ & & $\begin{array}{l}-0.263 \\
(0.999)\end{array}$ \\
\hline $\begin{array}{l}\text { US gamma } \mathrm{x} \\
\text { dollar zone weight }\left(\theta_{7}^{U S}\right)\end{array}$ & $\begin{array}{l}-0.364 \\
(0.201)^{*}\end{array}$ & & $\begin{array}{l}-0.352 \\
(0.203)^{*}\end{array}$ & $\begin{array}{l}-0.440 \\
(0.263)^{*}\end{array}$ & & $\begin{array}{l}-0.444 \\
(0.266)^{*}\end{array}$ & $\begin{array}{l}-0.485 \\
(0.265)^{*}\end{array}$ & & $\begin{array}{c}-0.496 \\
(0.267)^{*}\end{array}$ \\
\hline Euro zone weight $\left(\theta_{6}^{\text {Euro }}\right)$ & & $\begin{array}{l}-0.036 \\
(0.194)\end{array}$ & $\begin{array}{l}-0.012 \\
(0.386)\end{array}$ & & $\begin{array}{l}0.160 \\
(0.282)\end{array}$ & $\begin{array}{c}0.684 \\
(0.843)\end{array}$ & & $\begin{array}{r}0.199 \\
(0.301)\end{array}$ & $\begin{array}{l}-0.285 \\
(1.027)\end{array}$ \\
\hline $\begin{array}{l}\text { Euro area gamma } \\
\quad \mathrm{x} \text { euro zone Weight }\left(\theta_{7}^{\text {Euro }}\right)\end{array}$ & & $\begin{array}{c}0.277 \\
(0.344)\end{array}$ & $\begin{array}{c}0.260 \\
(0.348)\end{array}$ & & $\begin{array}{l}-0.298 \\
(0.559)\end{array}$ & $\begin{array}{l}-0.280 \\
(0.562)\end{array}$ & & $\begin{array}{l}-0.294 \\
(0.577)\end{array}$ & $\begin{array}{l}-0.319 \\
(0.575)\end{array}$ \\
\hline Financial Openness & $\begin{array}{c}0.359 \\
(0.164)^{* *}\end{array}$ & $\begin{array}{c}0.347 \\
(0.162)^{* *}\end{array}$ & $\begin{array}{c}0.372 \\
(0.164)^{* *}\end{array}$ & $\begin{array}{c}0.482 \\
(0.222)^{* *}\end{array}$ & $\begin{array}{c}0.431 \\
(0.224)^{*}\end{array}$ & $\begin{array}{c}0.545 \\
(0.244)^{* *}\end{array}$ & $\begin{array}{c}0.562 \\
(0.246)^{* *}\end{array}$ & $\begin{array}{c}0.547 \\
(0.247)^{* *}\end{array}$ & $\begin{array}{c}0.482 \\
(0.222)^{* *}\end{array}$ \\
\hline IR Holding & $\begin{array}{l}-0.568 \\
(0.481) \\
\end{array}$ & $\begin{array}{l}-0.580 \\
(0.475) \\
\end{array}$ & $\begin{array}{l}-0.584 \\
(0.481) \\
\end{array}$ & $\begin{array}{l}-1.044 \\
(0.656) \\
\end{array}$ & $\begin{array}{l}-0.907 \\
(0.666)\end{array}$ & $\begin{array}{l}-0.795 \\
(0.772)\end{array}$ & $\begin{array}{l}-0.977 \\
(0.772) \\
\end{array}$ & $\begin{array}{l}-0.791 \\
(0.778)\end{array}$ & $\begin{array}{l}-1.044 \\
(0.656)\end{array}$ \\
\hline \multicolumn{10}{|c|}{ Link 2 - CEs: Change in ST-rate $\rightarrow$ PH: REER changes } \\
\hline & $\begin{array}{l}\text { FULL } \\
\text { (1) }\end{array}$ & $\begin{array}{l}\text { FULL } \\
\text { (2) }\end{array}$ & $\begin{array}{l}\text { FULL } \\
\text { (3) }\end{array}$ & $\begin{array}{l}\mathrm{LDC} \\
(4)\end{array}$ & $\begin{array}{l}\mathrm{LDC} \\
(5)\end{array}$ & $\begin{array}{l}\mathrm{LDC} \\
(6)\end{array}$ & $\begin{array}{l}\text { EMG } \\
(7)\end{array}$ & $\begin{array}{c}\text { EMG } \\
(8)\end{array}$ & $\begin{array}{c}\text { EMG } \\
(9)\end{array}$ \\
\hline Exch. Rate Stability & $\begin{array}{c}1.532 \\
(0.465)^{* * *}\end{array}$ & $\begin{array}{c}1.468 \\
(0.472)^{* * * *}\end{array}$ & $\begin{array}{c}1.513 \\
(0.477)^{* * * *}\end{array}$ & $\begin{array}{c}2.091 \\
(0.622)^{* * *}\end{array}$ & $\begin{array}{c}2.096 \\
(0.627)^{* * *}\end{array}$ & $\begin{array}{c}2.243 \\
(0.637)^{* * *}\end{array}$ & $\begin{array}{c}2.451 \\
(0.721)^{* * * *}\end{array}$ & $\begin{array}{c}2.390 \\
(0.719) * * *\end{array}$ & $\begin{array}{c}2.526 \\
(0.738)^{* * * *}\end{array}$ \\
\hline$\$$ zone weight $\left(\theta_{6}^{U S}\right)$ & $\begin{array}{l}-0.483 \\
(0.367)\end{array}$ & & $\begin{array}{l}-0.408 \\
(0.748)\end{array}$ & $\begin{array}{l}-0.377 \\
(0.568)\end{array}$ & & $\begin{array}{l}-2.298 \\
(1.770)\end{array}$ & $\begin{array}{l}-0.611 \\
(0.681)\end{array}$ & & $\begin{array}{l}-1.601 \\
(2.351)\end{array}$ \\
\hline $\begin{array}{l}\text { US gamma x } \\
\text { dollar zone weight }\left(\theta_{7}^{U S}\right)\end{array}$ & $\begin{array}{l}0.025 \\
(0.479)\end{array}$ & & $\begin{array}{l}0.029 \\
(0.486)\end{array}$ & $\begin{array}{l}-0.084 \\
(0.622)\end{array}$ & & $\begin{array}{l}-0.161 \\
(0.630)\end{array}$ & $\begin{array}{l}-0.348 \\
(0.698)\end{array}$ & & $\begin{array}{l}-0.363 \\
(0.701)\end{array}$ \\
\hline Euro zone weight $\left(\theta_{6}^{\text {Euro }}\right)$ & & $\begin{array}{c}0.412 \\
(0.415)\end{array}$ & $\begin{array}{l}0.037 \\
(0.818)\end{array}$ & & $\begin{array}{l}0.150 \\
(0.616)\end{array}$ & $\begin{array}{l}-2.146 \\
(1.793)\end{array}$ & & $\begin{array}{l}0.640 \\
(0.740)\end{array}$ & $\begin{array}{l}-1.152 \\
(2.408)\end{array}$ \\
\hline $\begin{array}{l}\text { Euro area gamma } \\
\quad \text { x euro zone Weight }\left(\theta_{7}^{\text {Euro }}\right)\end{array}$ & & $\begin{array}{c}0.101 \\
(0.722)\end{array}$ & $\begin{array}{l}0.156 \\
(0.733)\end{array}$ & & $\begin{array}{c}0.458 \\
(1.200)\end{array}$ & $\begin{array}{c}0.454 \\
(1.210)\end{array}$ & & $\begin{array}{l}0.290 \\
(1.360)\end{array}$ & $\begin{array}{c}0.340 \\
(1.373)\end{array}$ \\
\hline Financial Openness & $\begin{array}{l}-0.071 \\
(0.378)\end{array}$ & $\begin{array}{l}-0.034 \\
(0.374)\end{array}$ & $\begin{array}{l}-0.063 \\
(0.379)\end{array}$ & $\begin{array}{l}0.482 \\
(0.532)\end{array}$ & $\begin{array}{c}0.458 \\
(0.533)\end{array}$ & $\begin{array}{l}0.519 \\
(0.539)\end{array}$ & $\begin{array}{l}0.958 \\
(0.635)\end{array}$ & $\begin{array}{l}0.920 \\
(0.631)\end{array}$ & $\begin{array}{c}0.985 \\
(0.638)\end{array}$ \\
\hline IR Holding & $\begin{array}{l}1.566 \\
(1.308) \\
\end{array}$ & $\begin{array}{c}1.491 \\
(1.296) \\
\end{array}$ & $\begin{array}{r}1.563 \\
(1.312) \\
\end{array}$ & $\begin{array}{c}0.446 \\
(1.828) \\
\end{array}$ & $\begin{array}{r}0.439 \\
(1.831) \\
\end{array}$ & $\begin{array}{c}0.244 \\
(1.853) \\
\end{array}$ & $\begin{array}{l}-0.074 \\
(2.081) \\
\end{array}$ & $\begin{array}{l}-0.047 \\
(2.066) \\
\end{array}$ & $\begin{array}{l}-0.174 \\
(2.086) \\
\end{array}$ \\
\hline & $\begin{array}{l}\text { FULL } \\
\text { (1) }\end{array}$ & $\begin{array}{l}\text { FULL } \\
\text { (2) }\end{array}$ & $\begin{array}{l}\text { FULL } \\
\text { (3) }\end{array}$ & $\begin{array}{l}\text { LDC } \\
(4)\end{array}$ & $\begin{array}{l}\text { LDC } \\
(5)\end{array}$ & $\begin{array}{l}\text { LDC } \\
(6)\end{array}$ & $\begin{array}{l}\text { EMG } \\
(7)\end{array}$ & $\begin{array}{c}\text { EMG } \\
(8)\end{array}$ & $\begin{array}{c}\text { EMG } \\
(9)\end{array}$ \\
\hline Exch. Rate Stability & $\begin{array}{c}0.589 \\
(0.055)^{* * *}\end{array}$ & $\begin{array}{c}0.592 \\
(0.056)^{* * *}\end{array}$ & $\begin{array}{c}0.583 \\
(0.056)^{* * *}\end{array}$ & $\begin{array}{c}0.635 \\
(0.069)^{* * *}\end{array}$ & $\begin{array}{c}0.696 \\
(0.070)^{* * *}\end{array}$ & $\begin{array}{c}0.648 \\
(0.069)^{* * *} *\end{array}$ & $\begin{array}{c}0.738 \\
(0.082)^{* * * *}\end{array}$ & $\begin{array}{c}0.795 \\
(0.084)^{* * *}\end{array}$ & $\begin{array}{c}0.751 \\
(0.084)^{* * * *}\end{array}$ \\
\hline$\$$ zone weight $\left(\theta_{6}^{U S}\right)$ & $\begin{array}{c}-0.116 \\
(0.043)^{* * *}\end{array}$ & & $\begin{array}{l}-0.120 \\
(0.087)\end{array}$ & $\begin{array}{l}-0.060 \\
(0.063)\end{array}$ & & $\begin{array}{l}-0.096 \\
(0.191)\end{array}$ & $\begin{array}{l}-0.063 \\
(0.078)\end{array}$ & & $\begin{array}{l}-0.030 \\
(0.268)\end{array}$ \\
\hline $\begin{array}{l}\text { US gamma } \mathrm{x} \\
\text { dollar zone weight }\left(\theta_{7}^{U S}\right)\end{array}$ & $\begin{array}{c}0.364 \\
(0.056)^{* * *}\end{array}$ & & $\begin{array}{c}0.376 \\
(0.057)^{* * *}\end{array}$ & $\begin{array}{c}0.403 \\
(0.069)^{* * *}\end{array}$ & & $\begin{array}{c}0.411 \\
(0.068)^{* * *}\end{array}$ & $\begin{array}{c}0.354 \\
(0.080)^{* * *}\end{array}$ & & $\begin{array}{c}0.372 \\
(0.080)^{* * * *}\end{array}$ \\
\hline Euro zone weight $\left(\theta_{6}^{\text {Euro }}\right)$ & & $\begin{array}{l}-0.075 \\
(0.049)\end{array}$ & $\begin{array}{l}-0.111 \\
(0.095)\end{array}$ & & $\begin{array}{c}-0.201 \\
(0.069)^{* * *}\end{array}$ & $\begin{array}{l}-0.156 \\
(0.194)\end{array}$ & & $\begin{array}{l}-0.159 \\
(0.086)^{*}\end{array}$ & $\begin{array}{l}-0.072 \\
(0.274)\end{array}$ \\
\hline $\begin{array}{l}\text { Euro area gamma } \\
\quad \text { x euro zone Weight }\left(\theta_{7}^{\text {Euro }}\right)\end{array}$ & & $\begin{array}{c}0.382 \\
(0.086)^{* * *}\end{array}$ & $\begin{array}{c}0.404 \\
(0.085)^{* * *}\end{array}$ & & $\begin{array}{c}0.416 \\
(0.134)^{* * *}\end{array}$ & $\begin{array}{c}0.433 \\
(0.131)^{* * *}\end{array}$ & & $\begin{array}{c}0.315 \\
(0.159)^{* *}\end{array}$ & $\begin{array}{c}0.370 \\
(0.156)^{* *}\end{array}$ \\
\hline Financial Openness & $\begin{array}{c}0.074 \\
(0.045)^{*}\end{array}$ & $\begin{array}{c}0.108 \\
(0.045)^{* *}\end{array}$ & $\begin{array}{c}0.077 \\
(0.044)^{*}\end{array}$ & $\begin{array}{r}0.082 \\
(0.059)\end{array}$ & $\begin{array}{l}0.083 \\
(0.059)\end{array}$ & $\begin{array}{c}0.080 \\
(0.058)\end{array}$ & $\begin{array}{l}-0.031 \\
(0.073)\end{array}$ & $\begin{array}{l}-0.018 \\
(0.074)\end{array}$ & $\begin{array}{l}-0.033 \\
(0.073)\end{array}$ \\
\hline IR Holding & $\begin{array}{c}0.571 \\
(0.154)^{* * *}\end{array}$ & $\begin{array}{c}0.575 \\
(0.155)^{* * *}\end{array}$ & $\begin{array}{c}0.559 \\
(0.153)^{* * *}\end{array}$ & $\begin{array}{c}0.539 \\
(0.201)^{* * *}\end{array}$ & $\begin{array}{c}0.709 \\
(0.204)^{* * *}\end{array}$ & $\begin{array}{c}0.547 \\
(0.200)^{* * *}\end{array}$ & $\begin{array}{c}0.350 \\
(0.238)\end{array}$ & $\begin{array}{c}0.472 \\
(0.241)^{*}\end{array}$ & $\begin{array}{c}0.352 \\
(0.238)\end{array}$ \\
\hline
\end{tabular}


Table 3: Continued

Link 4-CEs: REER changes $\rightarrow$ PHs: EMP

\begin{tabular}{|c|c|c|c|c|c|c|c|c|c|}
\hline & $\begin{array}{l}\text { FULL } \\
\text { (1) }\end{array}$ & $\begin{array}{l}\text { FULL } \\
(2)\end{array}$ & $\begin{array}{l}\text { FULL } \\
\text { (3) }\end{array}$ & $\begin{array}{l}\text { LDC } \\
(4)\end{array}$ & $\begin{array}{l}\mathrm{LDC} \\
(5)\end{array}$ & $\begin{array}{l}\text { LDC } \\
(6)\end{array}$ & $\begin{array}{l}\text { EMG } \\
(7)\end{array}$ & $\begin{array}{c}\text { EMG } \\
(8)\end{array}$ & $\begin{array}{l}\text { EMG } \\
(9)\end{array}$ \\
\hline Exch. Rate Stability & $\begin{array}{c}-7.831 \\
(2.118)^{* * *}\end{array}$ & $\begin{array}{c}-6.918 \\
(2.125)^{* * * *}\end{array}$ & $\begin{array}{c}-6.658 \\
(2.144)^{* * *}\end{array}$ & $\begin{array}{c}-7.549 \\
(2.177)^{* * * *}\end{array}$ & $\begin{array}{c}-7.239 \\
(2.165)^{* * *}\end{array}$ & $\begin{array}{c}-7.228 \\
(2.170)^{* * * *}\end{array}$ & $\begin{array}{c}-6.945 \\
(2.620)^{* * *}\end{array}$ & $\begin{array}{c}-6.633 \\
(2.641)^{* *}\end{array}$ & $\begin{array}{c}-7.517 \\
(2.706)^{* * *}\end{array}$ \\
\hline$\$$ zone weight $\left(\theta_{6}^{U S}\right)$ & $\begin{array}{l}0.766 \\
(1.705)\end{array}$ & & $\begin{array}{l}-7.544 \\
(3.562)^{* *}\end{array}$ & $\begin{array}{l}-0.172 \\
(2.026)\end{array}$ & & $\begin{array}{l}-4.103 \\
(6.315)\end{array}$ & $\begin{array}{l}0.312 \\
(2.377)\end{array}$ & & $\begin{array}{l}4.998 \\
(8.808)\end{array}$ \\
\hline $\begin{array}{l}\text { US gamma x } \\
\text { dollar zone weight }\left(\theta_{7}^{U S}\right)\end{array}$ & $\begin{array}{c}4.694 \\
(2.117)^{* *}\end{array}$ & & $\begin{array}{c}3.876 \\
(2.132)^{*}\end{array}$ & $\begin{array}{c}3.649 \\
(2.174)^{*}\end{array}$ & & $\begin{array}{l}3.629 \\
(2.153)^{*}\end{array}$ & $\begin{array}{c}5.616 \\
(2.414)^{* *}\end{array}$ & & $\begin{array}{c}5.556 \\
(2.434)^{* *}\end{array}$ \\
\hline Euro zone weight $\left(\theta_{6}^{\text {Euro }}\right)$ & & $\begin{array}{l}-0.645 \\
(1.959)\end{array}$ & $\begin{array}{l}-6.755 \\
(3.904)^{*}\end{array}$ & & $\begin{array}{l}1.172 \\
(2.228)\end{array}$ & $\begin{array}{l}-1.637 \\
(6.457)\end{array}$ & & $\begin{array}{l}0.557 \\
(2.675)\end{array}$ & $\begin{array}{r}7.277 \\
(9.072)\end{array}$ \\
\hline $\begin{array}{l}\text { Euro area gamma } \\
\quad \text { x euro zone Weight }\left(\theta_{7}^{\text {Euro }}\right)\end{array}$ & & $\begin{array}{l}-10.314 \\
(3.430)^{* * *}\end{array}$ & $\begin{array}{c}-9.750 \\
(3.466)^{* * *}\end{array}$ & & $\begin{array}{l}-9.132 \\
(4.376)^{* *}\end{array}$ & $\begin{array}{l}-9.140 \\
(4.363)^{* *}\end{array}$ & & $\begin{array}{l}-8.521 \\
(5.019)^{*}\end{array}$ & $\begin{array}{l}-8.168 \\
(5.038)\end{array}$ \\
\hline Financial Openness & $\begin{array}{l}-2.831 \\
(1.707)^{*}\end{array}$ & $\begin{array}{l}-2.276 \\
(1.679)\end{array}$ & $\begin{array}{l}-2.847 \\
(1.701)^{*}\end{array}$ & $\begin{array}{c}-4.613 \\
(1.799)^{* *}\end{array}$ & $\begin{array}{c}-4.463 \\
(1.785)^{* *}\end{array}$ & $\begin{array}{c}-4.476 \\
(1.784)^{* *}\end{array}$ & $\begin{array}{l}-4.855 \\
(2.211)^{* *}\end{array}$ & $\begin{array}{c}-4.447 \\
(2.212)^{* *}\end{array}$ & $\begin{array}{l}-4.920 \\
(2.232)^{* *}\end{array}$ \\
\hline IR Holding & $\begin{array}{l}-12.879 \\
(5.500)^{* *}\end{array}$ & $\begin{array}{c}-14.198 \\
(5.405)^{* * *}\end{array}$ & $\begin{array}{l}-12.963 \\
(5.477)^{* *}\end{array}$ & $\begin{array}{l}-1.655 \\
(5.800)\end{array}$ & $\begin{array}{l}-1.652 \\
(5.750)\end{array}$ & $\begin{array}{l}-2.204 \\
(5.749)\end{array}$ & $\begin{array}{l}-2.132 \\
(7.331)\end{array}$ & $\begin{array}{l}-2.359 \\
(7.354)\end{array}$ & $\begin{array}{l}-2.295 \\
(7.405)\end{array}$ \\
\hline
\end{tabular}

Link 5-CEs: REER changes $\rightarrow$ PH: Stock market price changes

\begin{tabular}{|c|c|c|c|c|c|c|c|c|c|}
\hline & $\begin{array}{l}\text { FULL } \\
\text { (1) }\end{array}$ & $\begin{array}{l}\text { FULL } \\
\text { (2) }\end{array}$ & $\begin{array}{l}\text { FULL } \\
\text { (3) }\end{array}$ & $\begin{array}{l}\text { LDC } \\
(4)\end{array}$ & $\begin{array}{l}\mathrm{LDC} \\
(5)\end{array}$ & $\begin{array}{l}\text { LDC } \\
(6)\end{array}$ & $\begin{array}{c}\text { EMG } \\
(7)\end{array}$ & $\begin{array}{c}\text { EMG } \\
(8)\end{array}$ & $\begin{array}{c}\text { EMG } \\
(9)\end{array}$ \\
\hline Exch. Rate Stability & $\begin{array}{l}-0.091 \\
(0.164)\end{array}$ & $\begin{array}{l}-0.066 \\
(0.172)\end{array}$ & $\begin{array}{l}-0.130 \\
(0.168)\end{array}$ & $\begin{array}{l}0.144 \\
(0.229)\end{array}$ & $\begin{array}{l}0.100 \\
(0.239)\end{array}$ & $\begin{array}{c}0.104 \\
(0.229)\end{array}$ & $\begin{array}{l}0.236 \\
(0.277)\end{array}$ & $\begin{array}{l}0.113 \\
(0.293)\end{array}$ & $\begin{array}{l}0.206 \\
(0.283)\end{array}$ \\
\hline$\$$ zone weight $\left(\theta_{6}^{U S}\right)$ & $\begin{array}{c}0.370 \\
(0.133)^{* * *}\end{array}$ & & $\begin{array}{c}0.541 \\
(0.249)^{* *}\end{array}$ & $\begin{array}{c}0.538 \\
(0.201)^{* * *}\end{array}$ & & $\begin{array}{c}1.503 \\
(0.602)^{* *}\end{array}$ & $\begin{array}{l}0.288 \\
(0.237)\end{array}$ & & $\begin{array}{c}0.661 \\
(0.856)\end{array}$ \\
\hline $\begin{array}{l}\text { US gamma x } \\
\text { dollar zone weight }\left(\theta_{7}^{U S}\right)\end{array}$ & $\begin{array}{c}-1.149 \\
(0.160)^{* * *}\end{array}$ & & $\begin{array}{l}-1.126 \\
(0.162)^{* * *}\end{array}$ & $\begin{array}{l}-1.522 \\
(0.208)^{* * * *}\end{array}$ & & $\begin{array}{c}-1.475 \\
(0.208)^{* * * *}\end{array}$ & $\begin{array}{c}-1.772 \\
(0.228)^{* * *}\end{array}$ & & $\begin{array}{c}-1.708 \\
(0.229)^{* * *}\end{array}$ \\
\hline Euro zone weight $\left(\theta_{6}^{\text {Euro }}\right)$ & & $\begin{array}{l}-0.078 \\
(0.155)\end{array}$ & $\begin{array}{c}0.207 \\
(0.268)\end{array}$ & & $\begin{array}{l}-0.193 \\
(0.232)\end{array}$ & $\begin{array}{l}0.846 \\
(0.603)\end{array}$ & & $\begin{array}{l}-0.019 \\
(0.286)\end{array}$ & $\begin{array}{l}0.185 \\
(0.871)\end{array}$ \\
\hline $\begin{array}{l}\text { Euro area gamma } \\
\quad \mathrm{x} \text { euro zone Weight }\left(\theta_{7}^{\text {Euro }}\right)\end{array}$ & & $\begin{array}{l}0.194 \\
(0.259)\end{array}$ & $\begin{array}{l}-0.010 \\
(0.253)\end{array}$ & & $\begin{array}{c}0.746 \\
(0.451)^{*}\end{array}$ & $\begin{array}{r}0.540 \\
(0.433)\end{array}$ & & $\begin{array}{c}1.158 \\
(0.531)^{* *}\end{array}$ & $\begin{array}{l}0.682 \\
(0.504)\end{array}$ \\
\hline Financial Openness & $\begin{array}{l}0.206 \\
(0.136)\end{array}$ & $\begin{array}{c}0.091 \\
(0.139)\end{array}$ & $\begin{array}{r}0.209 \\
(0.136)\end{array}$ & $\begin{array}{l}0.035 \\
(0.180)\end{array}$ & $\begin{array}{l}0.016 \\
(0.188)\end{array}$ & $\begin{array}{l}0.010 \\
(0.180)\end{array}$ & $\begin{array}{c}0.011 \\
(0.217)\end{array}$ & $\begin{array}{l}0.031 \\
(0.230)\end{array}$ & $\begin{array}{l}-0.004 \\
(0.218)\end{array}$ \\
\hline IR Holding & $\begin{array}{l}-0.612 \\
(0.388)\end{array}$ & $\begin{array}{l}-0.459 \\
(0.397)\end{array}$ & $\begin{array}{l}-0.610 \\
(0.388)\end{array}$ & $\begin{array}{l}-0.532 \\
(0.531)\end{array}$ & $\begin{array}{l}-0.655 \\
(0.554)\end{array}$ & $\begin{array}{l}-0.463 \\
(0.531)\end{array}$ & $\begin{array}{l}-0.430 \\
(0.704)\end{array}$ & $\begin{array}{l}-0.844 \\
(0.746)\end{array}$ & $\begin{array}{l}-0.439 \\
(0.710)\end{array}$ \\
\hline
\end{tabular}

Notes: The estimations are conducted with the robust regression method due to the existence of outliers. * $p<0.1$; ** $p<0.05 ; * * * p<0.01$. 
Table 4: Effects of External Debt

Link 1 CEs: ST rate in the CEs $\rightarrow$ PHs: ST rate

\begin{tabular}{|c|c|c|c|c|c|c|c|c|c|c|c|c|c|c|}
\hline & \multicolumn{7}{|c|}{ Developing Countries (LDC) } & \multicolumn{7}{|c|}{ Emerging Market Countries (EMG) } \\
\hline & (1) & (2) & (3) & (4) & (5) & (6) & (7) & (8) & (9) & (10) & (11) & (12) & (13) & (14) \\
\hline Exch. Rate Stability & $\begin{array}{c}0.087 \\
(0.265)\end{array}$ & $\begin{array}{c}0.033 \\
(0.261)\end{array}$ & $\begin{array}{l}-0.195 \\
(0.381)\end{array}$ & $\begin{array}{l}-0.179 \\
(0.391)\end{array}$ & $\begin{array}{l}-0.314 \\
(0.428)\end{array}$ & $\begin{array}{l}-0.281 \\
(0.383)\end{array}$ & $\begin{array}{l}-0.178 \\
(0.387)\end{array}$ & $\begin{array}{c}0.200 \\
(0.294)\end{array}$ & $\begin{array}{c}0.185 \\
(0.303)\end{array}$ & $\begin{array}{c}0.223 \\
(0.429)\end{array}$ & $\begin{array}{c}0.161 \\
(0.457)\end{array}$ & $\begin{array}{c}0.116 \\
(0.526)\end{array}$ & $\begin{array}{c}0.052 \\
(0.427)\end{array}$ & $\begin{array}{c}0.175 \\
(0.426)\end{array}$ \\
\hline Financial Openness & $\begin{array}{c}0.461 \\
(0.228)^{* *}\end{array}$ & $\begin{array}{c}0.474 \\
(0.233)^{* *}\end{array}$ & $\begin{array}{c}0.512 \\
(0.345)\end{array}$ & $\begin{array}{c}0.517 \\
(0.346)\end{array}$ & $\begin{array}{c}0.496 \\
(0.381)\end{array}$ & $\begin{array}{c}0.551 \\
(0.345)\end{array}$ & $\begin{array}{c}0.519 \\
(0.344)\end{array}$ & $\begin{array}{c}0.531 \\
(0.257)^{* *}\end{array}$ & $\begin{array}{c}0.473 \\
(0.266)^{*}\end{array}$ & $\begin{array}{c}0.657 \\
(0.387)^{*}\end{array}$ & $\begin{array}{c}0.658 \\
(0.387)^{*}\end{array}$ & $\begin{array}{c}0.514 \\
(0.454)\end{array}$ & $\begin{array}{c}0.652 \\
(0.385)^{*}\end{array}$ & $\begin{array}{c}0.658 \\
(0.387)^{*}\end{array}$ \\
\hline IR Holding & $\begin{array}{l}-0.898 \\
(0.680)\end{array}$ & $\begin{array}{l}-1.007 \\
(0.663)\end{array}$ & $\begin{array}{l}-1.068 \\
(1.050)\end{array}$ & $\begin{array}{l}-1.063 \\
(1.044)\end{array}$ & $\begin{array}{l}-1.080 \\
(1.170)\end{array}$ & $\begin{array}{l}-0.723 \\
(1.098)\end{array}$ & $\begin{array}{l}-1.134 \\
(1.079)\end{array}$ & $\begin{array}{l}-0.788 \\
(0.833)\end{array}$ & $\begin{array}{l}-0.767 \\
(0.844)\end{array}$ & $\begin{array}{l}-1.052 \\
(1.312)\end{array}$ & $\begin{array}{l}-1.004 \\
(1.327)\end{array}$ & $\begin{array}{l}-0.901 \\
(1.683)\end{array}$ & $\begin{array}{l}-0.257 \\
(1.488)\end{array}$ & $\begin{array}{l}-0.994 \\
(1.322)\end{array}$ \\
\hline $\begin{array}{l}\text { International debt } \\
\text { As \% of GNI }\end{array}$ & & $\begin{array}{c}0.153 \\
(0.660)\end{array}$ & & & & & & & $\begin{array}{c}0.423 \\
(0.779)\end{array}$ & & & & & \\
\hline $\begin{array}{l}\text { External debt } \\
\text { as } \% \text { exports }\end{array}$ & & & $\begin{array}{c}0.001 \\
(0.140)\end{array}$ & & & & & & & $\begin{array}{l}-0.055 \\
(0.189)\end{array}$ & & & & \\
\hline $\begin{array}{l}\text { External debt } \\
\qquad \text { as \% of GNI }\end{array}$ & & & & $\begin{array}{l}-0.036 \\
(0.374)\end{array}$ & & & & & & & $\begin{array}{c}0.032 \\
(0.491)\end{array}$ & & & \\
\hline $\begin{array}{l}\text { Short-term debt } \\
\qquad \text { as \% of Exports }\end{array}$ & & & & & $\begin{array}{l}-0.812 \\
(0.833)\end{array}$ & & & & & & & $\begin{array}{l}-0.794 \\
(1.060)\end{array}$ & & \\
\hline $\begin{array}{l}\text { Short-term debt } \\
\text { as \% of External debt }\end{array}$ & & & & & & $\begin{array}{l}-0.992 \\
(1.040)\end{array}$ & & & & & & & $\begin{array}{l}-1.080 \\
(1.178)\end{array}$ & \\
\hline $\begin{array}{l}\text { Short-term debt } \\
\text { as \% of IR }\end{array}$ & & & & & & & $\begin{array}{l}-0.116 \\
(0.293)\end{array}$ & & & & & & & $\begin{array}{c}0.013 \\
(0.333)\end{array}$ \\
\hline$N$ & 809 & 723 & 532 & 532 & 511 & 532 & 532 & 590 & 572 & 377 & 377 & 356 & 377 & 377 \\
\hline Adj. R2 & 0.01 & 0.01 & -0.00 & -0.00 & -0.00 & 0.00 & -0.00 & 0.02 & 0.02 & 0.00 & 0.00 & -0.01 & 0.00 & 0.00 \\
\hline \# of countries & 63 & 53 & 44 & 44 & 44 & 44 & 44 & 39 & 38 & 25 & 25 & 25 & 25 & 25 \\
\hline
\end{tabular}

Link 2-CEs: Change in ST-rate $\rightarrow$ PH: REER changes

\begin{tabular}{|c|c|c|c|c|c|c|c|c|c|c|c|c|c|c|}
\hline & \multicolumn{7}{|c|}{ Developing Countries (LDC) } & \multicolumn{7}{|c|}{ Emerging Market Countries (EMG) } \\
\hline & (1) & (2) & (3) & (4) & (5) & (6) & (7) & (8) & (9) & (10) & (11) & (12) & & \\
\hline Exch. Rate Stability & $\begin{array}{c}2.486 \\
(0.648) * * *\end{array}$ & $\begin{array}{c}2.818 \\
(0.667)^{* * * *}\end{array}$ & $\begin{array}{c}2.286 \\
\left(0.8711^{* * * *}\right.\end{array}$ & $\begin{array}{c}2.238 \\
(0.903)^{* *}\end{array}$ & $\begin{array}{c}2.233 \\
(0.941)^{* *}\end{array}$ & $\begin{array}{c}2.179 \\
(0.894) * *\end{array}$ & $\begin{array}{c}2.391 \\
(0.892)^{* * * *}\end{array}$ & $\begin{array}{c}2.990 \\
(0.748) * * *\end{array}$ & $\begin{array}{c}3.386 \\
(0.786) * * *\end{array}$ & $\begin{array}{c}3.520 \\
(0.907) * * *\end{array}$ & $\begin{array}{c}3.951 \\
(0.997) * * *\end{array}$ & $\begin{array}{c}3.217 \\
(1.070) * * *\end{array}$ & $\begin{array}{c}3.357 \\
(0.999) * * *\end{array}$ & $\begin{array}{c}3.413 \\
\left(0.9211^{* * *}\right.\end{array}$ \\
\hline Financial Openness & $\begin{array}{c}0.282 \\
(0.546)\end{array}$ & $\begin{array}{c}0.496 \\
(0.584)\end{array}$ & $\begin{array}{c}0.078 \\
(0.802)\end{array}$ & $\begin{array}{r}-0.022 \\
(0.807)\end{array}$ & $\begin{array}{r}-0.133 \\
(0.815)\end{array}$ & $\begin{array}{l}-0.039 \\
(0.803)\end{array}$ & $\begin{array}{l}-0.094 \\
(0.799)\end{array}$ & $\begin{array}{c}0.648 \\
(0.657)\end{array}$ & $\begin{array}{c}0.781 \\
(0.682)\end{array}$ & $\begin{array}{c}0.902 \\
(0.911)\end{array}$ & $\begin{array}{c}0.656 \\
(0.926)\end{array}$ & $\begin{array}{c}0.816 \\
(0.954)\end{array}$ & $\begin{array}{c}0.763 \\
(0.919)\end{array}$ & $\begin{array}{c}0.808 \\
(0.921)\end{array}$ \\
\hline IR Holding & $\begin{array}{l}-0.163 \\
(1.904)\end{array}$ & $\begin{array}{c}0.198 \\
(1.921)\end{array}$ & $\begin{array}{l}-0.885 \\
(3.167)\end{array}$ & $\begin{array}{l}-1.114 \\
(3.226)\end{array}$ & $\begin{array}{l}-1.963 \\
(3.279)\end{array}$ & $\begin{array}{l}-1.240 \\
(3.198)\end{array}$ & $\begin{array}{l}-2.873 \\
(3.453)\end{array}$ & $\begin{array}{l}-0.252 \\
(2.205)\end{array}$ & $\begin{array}{l}-0.114 \\
(2.237)\end{array}$ & $\begin{array}{l}-0.047 \\
(3.161)\end{array}$ & $\begin{array}{l}1.278 \\
(3.266)\end{array}$ & $\begin{array}{c}0.340 \\
(3.364)\end{array}$ & $\begin{array}{c}0.679 \\
(3.287)\end{array}$ & $\begin{array}{l}-0.780 \\
(3.411)\end{array}$ \\
\hline $\begin{array}{l}\text { International debt } \\
\text { as \% of GNI }\end{array}$ & & $\begin{array}{c}-4.853 \\
(1.982)^{* *}\end{array}$ & & & & & & & $\begin{array}{l}-4.330 \\
(2.374)^{*}\end{array}$ & & & & & \\
\hline $\begin{array}{l}\text { External debt } \\
\text { as \% exports }\end{array}$ & & & $\begin{array}{l}-0.518 \\
(0.348)\end{array}$ & & & & & & & $\begin{array}{c}-1.069 \\
(0.501)^{* *}\end{array}$ & & & & \\
\hline $\begin{array}{l}\text { External debt } \\
\text { as \% of GNI }\end{array}$ & & & & $\begin{array}{l}-0.140 \\
(0.905)\end{array}$ & & & & & & & $\begin{array}{l}-1.935 \\
(1.217)\end{array}$ & & & \\
\hline $\begin{array}{l}\text { Short-term debt } \\
\text { as \% of Exports }\end{array}$ & & & & & $\begin{array}{l}-3.470 \\
(2.106)\end{array}$ & & & & & & & $\begin{array}{l}-2.822 \\
(2.417)\end{array}$ & & \\
\hline $\begin{array}{l}\text { Short-term debt } \\
\text { as \% of External debt }\end{array}$ & & & & & & $\begin{array}{l}-0.302 \\
(2.717)\end{array}$ & & & & & & & $\begin{array}{c}1.130 \\
(3.222)\end{array}$ & \\
\hline $\begin{array}{l}\text { Short-term debt } \\
\text { as \% of IR }\end{array}$ & & & & & & & $\begin{array}{l}-0.664 \\
(0.668)\end{array}$ & & & & & & & $\begin{array}{c}-0.989 \\
(0.751)\end{array}$ \\
\hline$N$ & 641 & 589 & 372 & 372 & 363 & 372 & 372 & 499 & 490 & 284 & 284 & 275 & 284 & $\frac{284}{284}$ \\
\hline Adj. R2 & 0.03 & 0.05 & 0.01 & -0.00 & 0.01 & -0.00 & 0.00 & 0.05 & 0.05 & 0.08 & 0.08 & 0.08 & 0.06 & 0.07 \\
\hline$\#$ of countries & 46 & 41 & 28 & 28 & 28 & 28 & 28 & 32 & 32 & $\begin{array}{l}0.00 \\
18\end{array}$ & 18 & $\begin{array}{l}1.00 \\
18\end{array}$ & 18 & 18 \\
\hline
\end{tabular}


Link 3-CEs: Change in REER $\rightarrow$ PHs: Change in REER

\begin{tabular}{|c|c|c|c|c|c|c|c|c|c|c|c|c|c|c|}
\hline & \multicolumn{7}{|c|}{ Developing Countries (LDC) } & \multicolumn{7}{|c|}{ Emerging Market Countries (EMG) } \\
\hline & (1) & (2) & (3) & (4) & (5) & (6) & (7) & (8) & (9) & (10) & (11) & (12) & (13) & (14) \\
\hline Exch. Rate Stability & $\begin{array}{c}0.779 \\
(0.072 * * *\end{array}$ & $\begin{array}{c}0.801 \\
(0.074 * * *\end{array}$ & 0.671 & 0.709 & $\begin{array}{c}0.652 \\
(0.098 * * *\end{array}$ & $\begin{array}{c}0.664 \\
0.064 * *\end{array}$ & 0.685 & 0.862 & 0.881 & 0.863 & 0.964 & 0.813 & 0.847 & 0.849 \\
\hline & $(0.072) * * *$ & $(0.074) * * *$ & $(0.092)^{* * *}$ & $(0.094) * * *$ & $(0.098)^{* * * *}$ & $(0.094) * * *$ & $(0.094)^{* * * *}$ & $(0.087)^{* * * *}$ & $(0.089) * * *$ & $(0.107) * * *$ & $(0.113)^{* * *}$ & $(0.123)^{* * * *}$ & $(0.116) * * *$ & $(0.107)^{* * * *}$ \\
\hline Financial Openness & $\begin{array}{c}0.093 \\
(0.060)\end{array}$ & $\begin{array}{c}0.071 \\
(0.065)\end{array}$ & $\begin{array}{l}-0.014 \\
(0.085)\end{array}$ & $\begin{array}{l}-0.003 \\
(0.084)\end{array}$ & $\begin{array}{l}-0.023 \\
(0.085)\end{array}$ & $\begin{array}{l}-0.023 \\
(0.084)\end{array}$ & $\begin{array}{l}-0.022 \\
(0.084)\end{array}$ & $\begin{array}{l}-0.029 \\
(0.076)\end{array}$ & $\begin{array}{l}-0.040 \\
(0.077)\end{array}$ & $\begin{array}{l}-0.170 \\
(0.107)\end{array}$ & $\begin{array}{l}-0.177 \\
(0.105)^{*}\end{array}$ & $\begin{array}{l}-0.162 \\
(0.110)\end{array}$ & $\begin{array}{l}-0.180 \\
(0.107)^{*}\end{array}$ & $\begin{array}{l}-0.183 \\
(0.107)^{*}\end{array}$ \\
\hline IR Holding & $\begin{array}{c}0.806 \\
(0.210) * * *\end{array}$ & $\begin{array}{c}0.772 \\
(0.214)^{* * *}\end{array}$ & $\begin{array}{c}0.958 \\
(0.336) * * *\end{array}$ & $\begin{array}{c}1.014 \\
(0.336)^{* * *}\end{array}$ & $\begin{array}{c}0.999 \\
(0.340)^{* * *}\end{array}$ & $\begin{array}{c}0.973 \\
(0.335)^{* * *}\end{array}$ & $\begin{array}{c}0.876 \\
(0.362)^{* *}\end{array}$ & $\begin{array}{c}0.610 \\
(0.255)^{* *}\end{array}$ & $\begin{array}{c}0.641 \\
(0.252)^{* *}\end{array}$ & $\begin{array}{c}0.790 \\
(0.372)^{* *}\end{array}$ & $\begin{array}{c}0.937 \\
(0.369)^{* *}\end{array}$ & $\begin{array}{c}0.930 \\
(0.387)^{* *}\end{array}$ & $\begin{array}{c}0.872 \\
(0.382)^{* *}\end{array}$ & $\begin{array}{c}0.892 \\
(0.397)^{* *}\end{array}$ \\
\hline $\begin{array}{l}\text { International debt } \\
\text { As \% of GNI }\end{array}$ & & $\begin{array}{c}0.164 \\
(0.220)\end{array}$ & & & & & & & $\begin{array}{c}0.150 \\
(0.268)\end{array}$ & & & & & \\
\hline $\begin{array}{l}\text { External debt } \\
\text { as \% exports }\end{array}$ & & & $\begin{array}{l}-0.025 \\
(0.037)\end{array}$ & & & & & & & $\begin{array}{l}-0.069 \\
(0.059)\end{array}$ & & & & \\
\hline $\begin{array}{l}\text { External debt } \\
\text { as } \% \text { of GNI }\end{array}$ & & & & $\begin{array}{l}-0.162 \\
(0.094)^{*}\end{array}$ & & & & & & & $\begin{array}{c}-0.389 \\
(0.137)^{* * *}\end{array}$ & & & \\
\hline $\begin{array}{l}\text { Short-term debt } \\
\text { as \% of Exports }\end{array}$ & & & & & $\begin{array}{l}-0.414 \\
(0.219)^{*}\end{array}$ & & & & & & & $\begin{array}{l}-0.427 \\
(0.278)\end{array}$ & & \\
\hline $\begin{array}{l}\text { Short-term debt } \\
\text { as \% of External debt }\end{array}$ & & & & & & $\begin{array}{l}-0.169 \\
(0.284)\end{array}$ & & & & & & & $\begin{array}{l}-0.067 \\
(0.375)\end{array}$ & \\
\hline $\begin{array}{l}\text { Short-term debt } \\
\text { as \% of IR }\end{array}$ & & & & & & & $\begin{array}{l}-0.040 \\
(0.070)\end{array}$ & & & & & & & $\begin{array}{c}0.039 \\
(0.087)\end{array}$ \\
\hline$N$ & 641 & 589 & 372 & 372 & 363 & 372 & 372 & 499 & 490 & 284 & 284 & 275 & 284 & 284 \\
\hline Adj. R2 & 0.27 & 0.28 & 0.30 & 0.31 & 0.31 & 0.30 & 0.30 & 0.27 & 0.28 & 0.33 & 0.36 & 0.32 & 0.33 & 0.32 \\
\hline \# of countries & 46 & 41 & 28 & 28 & 28 & 28 & 28 & 32 & 32 & 18 & 18 & 18 & 18 & 18 \\
\hline \multicolumn{15}{|c|}{ Link 4-CEs: REER changes $\rightarrow$ PHs: EMP } \\
\hline & \multicolumn{7}{|c|}{ Developing Countries (LDC) } & \multicolumn{7}{|c|}{ Emerging Market Countries (EMG) } \\
\hline & (1) & (2) & (3) & (4) & (5) & (6) & (7) & (8) & (9) & (10) & (11) & (12) & (13) & (14) \\
\hline Exch. Rate Stability & -8.357 & -8.742 & -9.272 & -9.598 & -10.610 & -9.389 & -9.406 & -7.307 & -6.679 & -12.201 & -14.252 & -11.513 & -8.252 & -11.554 \\
\hline & $(2.261)^{* * * *}$ & $(2.324)^{* * * *}$ & $(3.199)^{* * * *}$ & $(3.278)^{* * *}$ & $(3.561) * * *$ & $(3.183)^{* * * *}$ & $(3.273) * * *$ & $(2.735)^{* * * *}$ & $(2.757)^{* *}$ & $(4.490)^{* * * *}$ & $(4.766)^{* * * *}$ & $(5.279)^{* *}$ & $(4.410)^{*}$ & $(4.405)^{* * *}$ \\
\hline Financial Openness & -4.564 & -4.408 & -5.021 & -5.164 & -6.070 & -5.664 & -5.037 & -4.810 & -3.701 & -8.556 & -8.428 & -9.375 & -8.341 & -8.214 \\
\hline & $(1.833)^{* *}$ & $(1.961)^{* *}$ & $(2.646)^{*}$ & $(2.663)^{*}$ & $(2.842)^{* *}$ & $(2.638)^{* *}$ & $(2.652)^{*}$ & $(2.280)^{* * *}$ & $(2.302)$ & $(3.739)^{* *}$ & $(3.705)^{* *}$ & $(4.051)^{* *}$ & $(3.642) * *$ & $(3.731)^{* *}$ \\
\hline IR Holding & $\begin{array}{c}0.912 \\
(5.904)\end{array}$ & $\begin{array}{c}2.664 \\
(6.145)\end{array}$ & $\begin{array}{l}8.122 \\
(8.893)\end{array}$ & $\begin{array}{c}7.981 \\
(8.964)\end{array}$ & $\begin{array}{l}5.500 \\
(9.609)\end{array}$ & $\begin{array}{c}6.569 \\
(8.939)\end{array}$ & $\begin{array}{l}8.786 \\
(9.191)\end{array}$ & $\begin{array}{c}2.192 \\
(7.793)\end{array}$ & $\begin{array}{l}-1.180 \\
(7.723)\end{array}$ & $\begin{array}{c}14.473 \\
(14.176)\end{array}$ & $\begin{array}{c}12.242 \\
(14.328)\end{array}$ & $\begin{array}{l}-5.565 \\
(17.023)\end{array}$ & $\begin{array}{c}-6.093 \\
(15.420)\end{array}$ & $\begin{array}{c}15.503 \\
(14.136)\end{array}$ \\
\hline $\begin{array}{l}\text { International debt } \\
\text { As \% of GNI }\end{array}$ & & $\begin{array}{l}-8.077 \\
(5.851)\end{array}$ & & & & & & & $\begin{array}{l}-12.042 \\
(6.632) *\end{array}$ & & & & & \\
\hline External debt & & & 0.474 & & & & & & & 3.497 & & & & \\
\hline $\begin{array}{l}\text { as \% exports } \\
\text { External debt }\end{array}$ & & & (1.137) & & & & & & & $(1.943)^{*}$ & & & & \\
\hline $\begin{array}{l}\text { External debt } \\
\text { as \% of GNI }\end{array}$ & & & & $\begin{array}{c}1.099 \\
(2.968)\end{array}$ & & & & & & & $\begin{array}{c}7.092 \\
(4.880)\end{array}$ & & & \\
\hline $\begin{array}{l}\text { Short-term debt } \\
\text { as \% of Exports }\end{array}$ & & & & & $\begin{array}{c}7.910 \\
(6.177)\end{array}$ & & & & & & & $\begin{array}{c}18.316 \\
(9.263)^{* *}\end{array}$ & & \\
\hline $\begin{array}{l}\text { Short-term debt } \\
\text { as \% of External debt }\end{array}$ & & & & & & $\begin{array}{l}14.792 \\
(8.002)^{*}\end{array}$ & & & & & & & $\begin{array}{c}37.532 \\
(11.245)^{* * * *}\end{array}$ & \\
\hline $\begin{array}{l}\text { Short-term debt } \\
\text { as \% of IR }\end{array}$ & & & & & & & $\begin{array}{c}0.676 \\
(2.325)\end{array}$ & & & & & & & $\begin{array}{c}4.291 \\
(3.224)\end{array}$ \\
\hline$N$ & 782 & 696 & 502 & 502 & 481 & 502 & 502 & 581 & 563 & 365 & 365 & 344 & 365 & 365 \\
\hline Adj. R2 & 0.06 & 0.08 & 0.07 & 0.07 & 0.08 & 0.07 & 0.07 & 0.04 & 0.05 & 0.06 & 0.05 & 0.07 & 0.09 & 0.05 \\
\hline \# of countries & 61 & 51 & 42 & 42 & 42 & 42 & 42 & 38 & 37 & 24 & 24 & 24 & 24 & 24 \\
\hline
\end{tabular}


Link 5-CEs: REER changes $\rightarrow$ PH: Stock market price changes

\begin{tabular}{|c|c|c|c|c|c|c|c|c|c|c|c|c|c|c|}
\hline & \multicolumn{7}{|c|}{ Developing Countries (LDC) } & \multicolumn{7}{|c|}{ Emerging Market Countries (EMG) } \\
\hline & (1) & (2) & (3) & (4) & (5) & (6) & (7) & (8) & (9) & (10) & (11) & (12) & (13) & (14) \\
\hline Exch. Rate Stability & $\begin{array}{c}0.246 \\
(0.254)\end{array}$ & $\begin{array}{c}0.214 \\
(0.269)\end{array}$ & $\begin{array}{c}1.688 \\
(0.423)^{* * *}\end{array}$ & $\begin{array}{c}1.737 \\
(0.430)^{* * * *}\end{array}$ & $\begin{array}{c}1.751 \\
(0.419)^{* * *}\end{array}$ & $\begin{array}{c}1.603 \\
(0.425) * * *\end{array}$ & $\begin{array}{c}1.659 \\
(0.427)^{* * *}\end{array}$ & $\begin{array}{c}0.394 \\
(0.316)\end{array}$ & $\begin{array}{c}0.224 \\
(0.328)\end{array}$ & $\begin{array}{c}1.872 \\
(0.522)^{* * *}\end{array}$ & $\begin{array}{c}1.824 \\
(0.526)^{* * * *}\end{array}$ & $\begin{array}{c}1.447 \\
(0.505)^{* * * *}\end{array}$ & $\begin{array}{c}1.290 \\
(0.538)^{* * *}\end{array}$ & $\begin{array}{c}1.518 \\
(0.521)^{* * *}\end{array}$ \\
\hline Financial Openness & $\begin{array}{c}0.060 \\
(0.197)\end{array}$ & $\begin{array}{c}0.051 \\
(0.211)\end{array}$ & $\begin{array}{c}0.590 \\
(0.316)^{*}\end{array}$ & $\begin{array}{c}0.613 \\
(0.330)^{*}\end{array}$ & $\begin{array}{c}0.511 \\
(0.308)^{*}\end{array}$ & $\begin{array}{c}0.462 \\
(0.315)\end{array}$ & $\begin{array}{c}0.509 \\
(0.311)\end{array}$ & $\begin{array}{c}0.115 \\
(0.245)\end{array}$ & $\begin{array}{c}0.193 \\
(0.250)\end{array}$ & $\begin{array}{c}0.360 \\
(0.358)\end{array}$ & $\begin{array}{c}0.418 \\
(0.367)\end{array}$ & $\begin{array}{c}0.352 \\
(0.352)\end{array}$ & $\begin{array}{c}0.202 \\
(0.362)\end{array}$ & $\begin{array}{c}0.319 \\
(0.360)\end{array}$ \\
\hline IR Holding & $\begin{array}{l}-0.590 \\
(0.567)\end{array}$ & $\begin{array}{l}-0.388 \\
(0.613)\end{array}$ & $\begin{array}{c}-2.213 \\
(0.916)^{* *}\end{array}$ & $\begin{array}{c}-2.056 \\
(0.910)^{* *}\end{array}$ & $\begin{array}{c}-2.084 \\
(0.898)^{* * *}\end{array}$ & $\begin{array}{c}-1.892 \\
(0.917)^{* *}\end{array}$ & $\begin{array}{c}-2.022 \\
(0.953)^{* * *}\end{array}$ & $\begin{array}{l}-1.252 \\
(0.801)\end{array}$ & $\begin{array}{l}-0.969 \\
(0.805)\end{array}$ & $\begin{array}{c}-3.350 \\
(1.407)^{* *}\end{array}$ & $\begin{array}{c}-2.944 \\
(1.426)^{* *}\end{array}$ & $\begin{array}{l}-2.354 \\
(1.385)^{*}\end{array}$ & $\begin{array}{l}-2.114 \\
(1.473)\end{array}$ & $\begin{array}{c}-3.568 \\
(1.422)^{* *}\end{array}$ \\
\hline $\begin{array}{l}\text { International debt } \\
\text { As \% of GNI }\end{array}$ & & $\begin{array}{c}0.044 \\
(0.610)\end{array}$ & & & & & & & $\begin{array}{l}-0.196 \\
(0.669)\end{array}$ & & & & & \\
\hline $\begin{array}{l}\text { External debt } \\
\qquad \text { as \% exports }\end{array}$ & & & $\begin{array}{l}-0.157 \\
(0.129)\end{array}$ & & & & & & & $\begin{array}{l}-0.270 \\
(0.186)\end{array}$ & & & & \\
\hline $\begin{array}{l}\text { External debt } \\
\qquad \text { as \% of GNI }\end{array}$ & & & & $\begin{array}{l}-0.327 \\
(0.407)\end{array}$ & & & & & & & $\begin{array}{l}-0.551 \\
(0.565)\end{array}$ & & & \\
\hline $\begin{array}{l}\text { Short-term debt } \\
\text { as \% of Exports }\end{array}$ & & & & & $\begin{array}{c}-2.616 \\
(0.756)^{* * *}\end{array}$ & & & & & & & $\begin{array}{c}-3.387 \\
(0.851)^{* * *}\end{array}$ & & \\
\hline $\begin{array}{l}\text { Short-term debt } \\
\text { as \% of External debt }\end{array}$ & & & & & & $\begin{array}{l}-1.103 \\
(0.953)\end{array}$ & & & & & & & $\begin{array}{c}-2.245 \\
(1.131)^{* * *}\end{array}$ & \\
\hline $\begin{array}{l}\text { Short-term debt } \\
\text { as \% of IR }\end{array}$ & & & & & & & $\begin{array}{r}0.014 \\
(0.259) \\
\end{array}$ & & & & & & & $\begin{array}{c}-0.691 \\
(0.392)^{*}\end{array}$ \\
\hline$N$ & 570 & 545 & 310 & 310 & 310 & 310 & 310 & 473 & 466 & 271 & 271 & 271 & 271 & 271 \\
\hline Adj. R2 & 0.12 & 0.12 & 0.16 & 0.16 & 0.19 & 0.16 & 0.15 & 0.13 & 0.12 & 0.16 & 0.16 & 0.20 & 0.16 & 0.16 \\
\hline \# of countries & 40 & 38 & 22 & 22 & 22 & 22 & 22 & 32 & 31 & 18 & 18 & 18 & 18 & 18 \\
\hline
\end{tabular}


Table 5: Effects of External Debt and Currency Weights

Link 1 CEs: ST rate in the CEs $\rightarrow$ PHs: ST rate

\begin{tabular}{|c|c|c|c|c|c|c|c|c|c|c|c|c|}
\hline & \multicolumn{6}{|c|}{ Developing Countries (LDC) } & \multicolumn{6}{|c|}{ Emerging Market Countries (EMG) } \\
\hline & (1) & (2) & (3) & (4) & (5) & (6) & (7) & (8) & (9) & (10) & (11) & (12) \\
\hline Exch. Rate Stability & $\begin{array}{l}0.087 \\
(0.265)\end{array}$ & $\begin{array}{c}0.124 \\
(0.296)\end{array}$ & $\begin{array}{l}-0.251 \\
(0.381)\end{array}$ & $\begin{array}{l}-0.010 \\
(0.342)\end{array}$ & $\begin{array}{c}0.492 \\
(0.403)\end{array}$ & $\begin{array}{l}-0.028 \\
(0.334)\end{array}$ & $\begin{array}{c}0.200 \\
(0.294)\end{array}$ & $\begin{array}{c}0.234 \\
(0.331)\end{array}$ & $\begin{array}{l}-0.130 \\
(0.435)\end{array}$ & $\begin{array}{l}-0.011 \\
(0.446)\end{array}$ & $\begin{array}{c}0.500 \\
(0.444)\end{array}$ & $\begin{array}{l}0.054 \\
(0.353)\end{array}$ \\
\hline Financial Openness & $\begin{array}{c}0.461 \\
(0.228)^{* *}\end{array}$ & $\begin{array}{c}0.444 \\
(0.254)^{*}\end{array}$ & $\begin{array}{c}0.645 \\
(0.344)^{*}\end{array}$ & $\begin{array}{c}0.374 \\
(0.283)\end{array}$ & $\begin{array}{c}0.639 \\
(0.353)^{*}\end{array}$ & $\begin{array}{c}0.543 \\
(0.286)^{*}\end{array}$ & $\begin{array}{c}0.531 \\
(0.257)^{* *}\end{array}$ & $\begin{array}{c}0.640 \\
(0.279)^{* *}\end{array}$ & $\begin{array}{c}0.700 \\
(0.394)^{*}\end{array}$ & $\begin{array}{c}0.456 \\
(0.328)\end{array}$ & $\begin{array}{c}0.666 \\
(0.359)^{*}\end{array}$ & $\begin{array}{l}0.498 \\
(0.303)\end{array}$ \\
\hline IR Holding & $\begin{array}{l}-0.898 \\
(0.680)\end{array}$ & $\begin{array}{l}-0.965 \\
(0.709)\end{array}$ & $\begin{array}{l}-1.272 \\
(1.053)\end{array}$ & $\begin{array}{l}-0.928 \\
(0.765)\end{array}$ & $\begin{array}{l}-0.674 \\
(1.058)\end{array}$ & $\begin{array}{l}-0.893 \\
(0.824)\end{array}$ & $\begin{array}{l}-0.788 \\
(0.833)\end{array}$ & $\begin{array}{l}-0.831 \\
(0.916)\end{array}$ & $\begin{array}{l}-0.998 \\
(1.358)\end{array}$ & $\begin{array}{l}-0.483 \\
(1.049)\end{array}$ & $\begin{array}{l}-0.623 \\
(1.098)\end{array}$ & $\begin{array}{l}-0.666 \\
(1.023)\end{array}$ \\
\hline Dollar-denom. Int'l debt $(\%)$ & & $\begin{array}{l}-0.271 \\
(0.298)\end{array}$ & & & & & & $\begin{array}{l}-0.140 \\
(0.349)\end{array}$ & & & & \\
\hline Dollar share x US gamma & & $\begin{array}{l}-0.222 \\
(0.287)\end{array}$ & & & & & & $\begin{array}{l}-0.350 \\
(0.289)\end{array}$ & & & & \\
\hline $\begin{array}{l}\text { Public debt } \\
\text { denominated in USD (\%) }\end{array}$ & & & $\begin{array}{l}-0.512 \\
(0.542)\end{array}$ & & & & & & $\begin{array}{l}-0.241 \\
(0.569)\end{array}$ & & & \\
\hline Dollar share (PPG) x US gamma & & & $\begin{array}{l}-0.471 \\
(0.578)\end{array}$ & & & & & & $\begin{array}{l}-0.827 \\
(0.599)\end{array}$ & & & \\
\hline Dollar-denom. Int'l debt $(\%)$ & & & & 0.174 & & & & & & 0.054 & & \\
\hline Financial Inst. & & & & $(0.277)$ & & & & & & $(0.346)$ & & \\
\hline Dollar share x US gamma & & & & $\begin{array}{c}-0.723 \\
(0.289)^{* *}\end{array}$ & & & & & & $\begin{array}{l}-0.703 \\
(0.301)^{* *}\end{array}$ & & \\
\hline $\begin{array}{l}\text { Dollar-denom. Int'l debt }(\%) \\
\text { Non-Financial Inst. }\end{array}$ & & & & & $\begin{array}{l}-0.567 \\
(0.351)\end{array}$ & & & & & & $\begin{array}{l}-0.747 \\
(0.389)^{*}\end{array}$ & \\
\hline $\begin{array}{c}\text { Dollar-denom. Int'l debt }(\%) \backslash \\
\text { Gov't sector }\end{array}$ & & & & & & $\begin{array}{c}0.022 \\
(0.360)\end{array}$ & & & & & & $\begin{array}{c}0.224 \\
(0.370)\end{array}$ \\
\hline $\begin{array}{c}\text { Dollar share x US gamma } \\
\text { Gov't Sector }\end{array}$ & & & & & & $\begin{array}{l}-0.160 \\
(0.331)\end{array}$ & & & & & & $\begin{array}{l}-0.296 \\
(0.336)\end{array}$ \\
\hline $\mathrm{N}$ & 809 & 565 & 532 & 545 & 429 & 553 & 590 & 445 & 377 & 426 & 372 & 468 \\
\hline Adj. R2 & 0.01 & 0.01 & 0.00 & 0.06 & 0.07 & -0.00 & 0.02 & 0.03 & 0.01 & 0.07 & 0.08 & 0.01 \\
\hline \# of countries & 63 & 40 & 44 & 45 & 35 & 44 & 39 & 29 & 25 & 32 & 28 & 34 \\
\hline
\end{tabular}


Link 2 - CEs: Change in ST-rate $\rightarrow$ PH: REER changes

\begin{tabular}{|c|c|c|c|c|c|c|c|c|c|c|c|c|}
\hline & \multicolumn{6}{|c|}{ Developing Countries (LDC) } & \multicolumn{6}{|c|}{ Emerging Market Countries (EMG) } \\
\hline & (1) & (2) & (3) & (4) & (5) & (6) & (7) & (8) & (9) & $(10)$ & (11) & (12) \\
\hline Exch. Rate Stability & $\begin{array}{c}2.486 \\
(0.648) * * *\end{array}$ & $\begin{array}{c}3.306 \\
(0.768)^{* * *}\end{array}$ & $\begin{array}{c}2.385 \\
(0.909)^{* * *}\end{array}$ & $\begin{array}{c}3.684 \\
(0.979)^{* * *}\end{array}$ & $\begin{array}{c}4.639 \\
(1.196)^{* * *}\end{array}$ & $\begin{array}{c}3.476 \\
(0.882)^{* * * *}\end{array}$ & $\begin{array}{c}2.990 \\
(0.748)^{* * *}\end{array}$ & $\begin{array}{c}3.862 \\
(0.918) * * *\end{array}$ & $\begin{array}{c}3.182 \\
(0.937)^{* * * *}\end{array}$ & $\begin{array}{c}4.515 \\
(1.294)^{* * *}\end{array}$ & $\begin{array}{c}5.091 \\
(1.375)^{* * * *}\end{array}$ & $\begin{array}{c}3.733 \\
(0.951)^{* * * *}\end{array}$ \\
\hline Financial Openness & $\begin{array}{l}0.282 \\
(0.546)\end{array}$ & $\begin{array}{l}0.666 \\
(0.645)\end{array}$ & $\begin{array}{l}0.255 \\
(0.827)\end{array}$ & $\begin{array}{l}0.559 \\
(0.728)\end{array}$ & $\begin{array}{l}0.786 \\
(0.919)\end{array}$ & $\begin{array}{l}-0.048 \\
(0.737)\end{array}$ & $\begin{array}{l}0.648 \\
(0.657)\end{array}$ & $\begin{array}{l}1.167 \\
(0.775)\end{array}$ & $\begin{array}{c}1.392 \\
(0.990)\end{array}$ & $\begin{array}{r}1.079 \\
(0.935)\end{array}$ & $\begin{array}{l}1.045 \\
(0.996)\end{array}$ & $\begin{array}{l}0.293 \\
(0.805)\end{array}$ \\
\hline IR Holding & $\begin{array}{l}-0.163 \\
(1.904)\end{array}$ & $\begin{array}{l}-0.488 \\
(2.203)\end{array}$ & $\begin{array}{l}-1.570 \\
(3.206)\end{array}$ & $\begin{array}{c}0.134 \\
(2.546)\end{array}$ & $\begin{array}{l}-0.148 \\
(2.960)\end{array}$ & $\begin{array}{l}-1.955 \\
(2.726)\end{array}$ & $\begin{array}{l}-0.252 \\
(2.205)\end{array}$ & $\begin{array}{l}-0.753 \\
(2.603)\end{array}$ & $\begin{array}{c}0.121 \\
(3.190)\end{array}$ & $\begin{array}{l}-0.495 \\
(3.075)\end{array}$ & $\begin{array}{l}0.240 \\
(3.290)\end{array}$ & $\begin{array}{l}-1.519 \\
(2.932)\end{array}$ \\
\hline Dollar-denom. Int'l debt $(\%)$ & & $\begin{array}{l}-1.308 \\
(0.761)^{*}\end{array}$ & & & & & & $\begin{array}{l}-1.351 \\
(1.007)\end{array}$ & & & & \\
\hline Dollar share x US gamma & & $\begin{array}{l}0.019 \\
(0.714)\end{array}$ & & & & & & $\begin{array}{l}-0.625 \\
(0.800)\end{array}$ & & & & \\
\hline $\begin{array}{l}\text { Public debt } \\
\text { denominated in USD (\%) }\end{array}$ & & & $\begin{array}{l}-1.526 \\
(1.268)\end{array}$ & & & & & & $\begin{array}{l}-2.084 \\
(1.301)\end{array}$ & & & \\
\hline Dollar share (PPG) x US gamma & & & $\begin{array}{l}0.882 \\
(1.339)\end{array}$ & & & & & & $\begin{array}{c}0.834 \\
(1.261)\end{array}$ & & & \\
\hline $\begin{array}{l}\text { Dollar-denom. Int'l debt }(\%) \\
\text { Financial Inst. }\end{array}$ & & & & $\begin{array}{l}-0.281 \\
(0.711)\end{array}$ & & & & & & $\begin{array}{l}-0.162 \\
(1.033)\end{array}$ & & \\
\hline $\begin{array}{c}\text { Dollar share x US gamma } \\
\text { Financial Inst. }\end{array}$ & & & & $\begin{array}{l}-0.125 \\
(0.727)\end{array}$ & & & & & & $\begin{array}{l}-1.153 \\
(0.867)\end{array}$ & & \\
\hline $\begin{array}{l}\text { Dollar-denom. Int'l debt }(\%) \\
\text { Non-Financial Inst. }\end{array}$ & & & & & $\begin{array}{l}-1.410 \\
(0.893)\end{array}$ & & & & & & $\begin{array}{l}-2.544 \\
(1.079)^{* *}\end{array}$ & \\
\hline $\begin{array}{l}\text { Dollar share x US gamma } \\
\text { Non-Financial Inst. }\end{array}$ & & & & & $\begin{array}{l}-0.640 \\
(0.831)\end{array}$ & & & & & & $\begin{array}{l}-0.844 \\
(0.895)\end{array}$ & \\
\hline $\begin{array}{l}\text { Dollar-denom. Int'l debt }(\%) \backslash \\
\text { Gov't sector }\end{array}$ & & & & & & $\begin{array}{l}-1.820 \\
(0.897)^{* *}\end{array}$ & & & & & & $\begin{array}{l}-1.805 \\
(0.990)^{*}\end{array}$ \\
\hline $\begin{array}{l}\text { Dollar share x US gamma } \\
\text { Gov't Sector }\end{array}$ & & & & & & $\begin{array}{c}0.864 \\
(0.865)\end{array}$ & & & & & & $\begin{array}{l}0.489 \\
(0.913)\end{array}$ \\
\hline $\mathrm{N}$ & 641 & 512 & 372 & 472 & 388 & 466 & 499 & 422 & 284 & 391 & 352 & 415 \\
\hline Adj. R2 & 0.03 & 0.05 & -0.00 & 0.04 & 0.06 & 0.03 & 0.05 & 0.08 & 0.07 & 0.09 & 0.09 & 0.04 \\
\hline \# of countries & 46 & 34 & 28 & 36 & 30 & 35 & 32 & 27 & 18 & 28 & 25 & 30 \\
\hline
\end{tabular}


Link 3 - CEs: Change in REER $\rightarrow$ PHs: Change in REER

\begin{tabular}{|c|c|c|c|c|c|c|c|c|c|c|c|c|}
\hline & \multicolumn{6}{|c|}{ Developing Countries (LDC) } & \multicolumn{6}{|c|}{ Emerging Market Countries (EMG) } \\
\hline & (1) & (2) & (3) & (4) & (5) & (6) & (7) & (8) & (9) & (10) & (11) & (12) \\
\hline Exch. Rate Stability & $\begin{array}{c}0.779 \\
(0.072) * * *\end{array}$ & $\begin{array}{c}0.780 \\
(0.085)^{* * * *}\end{array}$ & $\begin{array}{c}0.707 \\
(0.096) * * *\end{array}$ & $\begin{array}{c}0.918 \\
(0.105)^{* * *}\end{array}$ & $\begin{array}{c}1.021 \\
(0.123)^{* * *}\end{array}$ & $\begin{array}{c}0.877 \\
(0.100)^{* * *}\end{array}$ & $\begin{array}{c}0.862 \\
(0.087)^{* * *}\end{array}$ & $\begin{array}{c}0.855 \\
(0.105)^{* * *}\end{array}$ & $\begin{array}{c}0.858 \\
(0.111)^{* * *}\end{array}$ & $\begin{array}{c}1.048 \\
(0.131)^{* * *}\end{array}$ & $\begin{array}{c}1.125 \\
(0.138)^{* * *}\end{array}$ & $\begin{array}{c}0.961 \\
(0.107)^{* * *}\end{array}$ \\
\hline Financial Openness & $\begin{array}{l}0.093 \\
(0.060)\end{array}$ & $\begin{array}{l}0.109 \\
(0.071)\end{array}$ & $\begin{array}{l}0.015 \\
(0.087)\end{array}$ & $\begin{array}{c}0.116 \\
(0.078)\end{array}$ & $\begin{array}{c}0.098 \\
(0.095)\end{array}$ & $\begin{array}{l}0.056 \\
(0.083)\end{array}$ & $\begin{array}{l}-0.029 \\
(0.076)\end{array}$ & $\begin{array}{l}0.044 \\
(0.089)\end{array}$ & $\begin{array}{l}-0.146 \\
(0.118)\end{array}$ & $\begin{array}{c}0.027 \\
(0.095)\end{array}$ & $\begin{array}{l}0.107 \\
(0.100)\end{array}$ & $\begin{array}{l}0.005 \\
(0.091)\end{array}$ \\
\hline IR Holding & $\begin{array}{c}0.806 \\
(0.210)^{* * *}\end{array}$ & $\begin{array}{c}0.812 \\
(0.243)^{* * * *}\end{array}$ & $\begin{array}{c}0.840 \\
(0.338)^{* *}\end{array}$ & $\begin{array}{c}1.121 \\
(0.272)^{* * *}\end{array}$ & $\begin{array}{c}1.143 \\
(0.306)^{* * *}\end{array}$ & $\begin{array}{l}0.429 \\
(0.308)\end{array}$ & $\begin{array}{c}0.610 \\
(0.255)^{* *}\end{array}$ & $\begin{array}{c}0.720 \\
(0.297)^{* *}\end{array}$ & $\begin{array}{c}0.746 \\
(0.379)^{*}\end{array}$ & $\begin{array}{c}1.048 \\
(0.311)^{* * *}\end{array}$ & $\begin{array}{c}1.114 \\
(0.331)^{* * *}\end{array}$ & $\begin{array}{l}0.233 \\
(0.331)\end{array}$ \\
\hline Dollar-denom. Int'l debt $(\%)$ & & $\begin{array}{l}-0.081 \\
(0.084)\end{array}$ & & & & & & $\begin{array}{l}0.063 \\
(0.115)\end{array}$ & & & & \\
\hline Dollar share $\mathrm{x}$ US gamma & & $\begin{array}{l}0.104 \\
(0.079)\end{array}$ & & & & & & $\begin{array}{c}0.074 \\
(0.091)\end{array}$ & & & & \\
\hline $\begin{array}{l}\text { Public debt } \\
\text { denominated in USD (\%) }\end{array}$ & & & $\begin{array}{l}-0.182 \\
(0.134)\end{array}$ & & & & & & $\begin{array}{l}-0.140 \\
(0.155)\end{array}$ & & & \\
\hline Dollar share (PPG) x US gamma & & & $\begin{array}{c}0.314 \\
(0.141)^{* *}\end{array}$ & & & & & & $\begin{array}{l}0.156 \\
(0.150)\end{array}$ & & & \\
\hline $\begin{array}{l}\text { Dollar-denom. Int'l debt }(\%) \\
\text { Financial Inst. }\end{array}$ & & & & $\begin{array}{c}0.038 \\
(0.076)\end{array}$ & & & & & & $\begin{array}{r}0.140 \\
(0.105)\end{array}$ & & \\
\hline $\begin{array}{c}\text { Dollar share x US gamma } \\
\text { Financial Inst. }\end{array}$ & & & & $\begin{array}{c}0.206 \\
(0.078)^{* * *}\end{array}$ & & & & & & $\begin{array}{c}0.156 \\
(0.088)^{*}\end{array}$ & & \\
\hline $\begin{array}{c}\text { Dollar-denom. Int'l debt }(\%) \\
\text { Non-Financial Inst. }\end{array}$ & & & & & $\begin{array}{c}0.138 \\
(0.092)\end{array}$ & & & & & & $\begin{array}{l}0.182 \\
(0.109) *\end{array}$ & \\
\hline $\begin{array}{c}\text { Dollar share x US gamma } \\
\text { Non-Financial Inst. }\end{array}$ & & & & & $\begin{array}{c}0.202 \\
(0.086)^{* *}\end{array}$ & & & & & & $\begin{array}{c}0.105 \\
(0.090)\end{array}$ & \\
\hline $\begin{array}{l}\text { Dollar-denom. Int'l debt }(\%) \backslash \\
\text { Gov't sector }\end{array}$ & & & & & & $\begin{array}{l}-0.096 \\
(0.101)\end{array}$ & & & & & & $\begin{array}{l}-0.120 \\
(0.112)\end{array}$ \\
\hline $\begin{array}{c}\text { Dollar share x US gamma } \\
\text { Gov't Sector }\end{array}$ & & & & & & $\begin{array}{c}0.316 \\
(0.098)^{* * * *}\end{array}$ & & & & & & $\begin{array}{c}0.270 \\
(0.103)^{* * *}\end{array}$ \\
\hline $\mathrm{N}$ & 641 & 512 & 372 & 472 & 388 & 466 & 499 & 422 & 284 & 391 & 352 & 415 \\
\hline Adj. R2 & 0.27 & 0.25 & 0.29 & 0.30 & 0.32 & 0.26 & 0.27 & 0.26 & 0.32 & 0.35 & 0.34 & 0.27 \\
\hline \# of countries & 46 & 34 & 28 & 36 & 30 & 35 & 32 & 27 & 18 & 28 & 25 & 30 \\
\hline
\end{tabular}


Link 4-CEs: REER changes $\rightarrow$ PHs: EMP

\begin{tabular}{|c|c|c|c|c|c|c|c|c|c|c|c|c|}
\hline & \multicolumn{6}{|c|}{ Developing Countries (LDC) } & \multicolumn{6}{|c|}{ Emerging Market Countries (EMG) } \\
\hline & (1) & (2) & (3) & (4) & (5) & (6) & (7) & (8) & (9) & (10) & (11) & (12) \\
\hline Exch. Rate Stability & $\begin{array}{c}-8.357 \\
(2.261)^{* * *}\end{array}$ & $\begin{array}{l}-12.503 \\
(2.703)^{* * *}\end{array}$ & $\begin{array}{c}-8.222 \\
(3.194)^{* *}\end{array}$ & $\begin{array}{c}-10.161 \\
(3.190) * * *\end{array}$ & $\begin{array}{c}-7.234 \\
(3.346)^{* *}\end{array}$ & $\begin{array}{l}-11.554 \\
(2.829)^{* * *}\end{array}$ & $\begin{array}{c}-7.307 \\
(2.735)^{* * * *}\end{array}$ & $\begin{array}{c}-9.988 \\
(3.062) * * *\end{array}$ & $\begin{array}{l}-5.346 \\
(4.599)\end{array}$ & $\begin{array}{c}-9.156 \\
(3.968) * *\end{array}$ & $\begin{array}{l}-6.606 \\
(3.748)^{*}\end{array}$ & $\begin{array}{l}-10.136 \\
(3.099)^{* * *}\end{array}$ \\
\hline Financial Openness & $\begin{array}{c}-4.564 \\
(1.833) * *\end{array}$ & $\begin{array}{c}-8.381 \\
(2.251)^{* * *}\end{array}$ & $\begin{array}{l}-5.065 \\
(2.617)^{*}\end{array}$ & $\begin{array}{c}-7.986 \\
(2.446) * * *\end{array}$ & $\begin{array}{l}-5.456 \\
(2.727)^{* *}\end{array}$ & $\begin{array}{l}-2.525 \\
(2.283)\end{array}$ & $\begin{array}{c}-4.810 \\
(2.280)^{* *}\end{array}$ & $\begin{array}{c}-7.870 \\
(2.577)^{* * *}\end{array}$ & $\begin{array}{l}-8.998 \\
(3.720)^{* *}\end{array}$ & $\begin{array}{c}-8.835 \\
(2.918)^{* * *}\end{array}$ & $\begin{array}{l}-5.328 \\
(2.901)^{*}\end{array}$ & $\begin{array}{l}-1.959 \\
(2.470)\end{array}$ \\
\hline IR Holding & $\begin{array}{c}0.912 \\
(5.904)\end{array}$ & $\begin{array}{l}-4.293 \\
(6.857)\end{array}$ & $\begin{array}{l}5.408 \\
(8.840)\end{array}$ & $\begin{array}{l}-5.966 \\
(7.184)\end{array}$ & $\begin{array}{l}-8.583 \\
(8.615)\end{array}$ & $\begin{array}{l}9.426 \\
(7.245)\end{array}$ & $\begin{array}{l}2.192 \\
(7.793)\end{array}$ & $\begin{array}{l}-9.726 \\
(8.883)\end{array}$ & $\begin{array}{c}10.333 \\
(14.296)\end{array}$ & $\begin{array}{c}-10.120 \\
(9.701)\end{array}$ & $\begin{array}{l}-3.111 \\
(9.293)\end{array}$ & $\begin{array}{l}9.620 \\
(9.167)\end{array}$ \\
\hline Dollar-denom. Int'l debt $(\%)$ & & $\begin{array}{l}-4.599 \\
(2.655)^{*}\end{array}$ & & & & & & $\begin{array}{l}-4.760 \\
(3.332)\end{array}$ & & & & \\
\hline Dollar share x US gamma & & $\begin{array}{c}7.932 \\
(2.569)^{* * *}\end{array}$ & & & & & & $\begin{array}{c}10.740 \\
(2.708) * * *\end{array}$ & & & & \\
\hline $\begin{array}{l}\text { Public debt } \\
\qquad \text { denominated in USD (\%) }\end{array}$ & & & $\begin{array}{c}8.584 \\
(4.265)^{* *}\end{array}$ & & & & & & $\begin{array}{c}14.049 \\
(5.556)^{* *}\end{array}$ & & & \\
\hline Dollar share (PPG) x US gamma & & & $\begin{array}{c}9.847 \\
(4.771)^{* *}\end{array}$ & & & & & & $\begin{array}{c}15.947 \\
(5.885)^{* * *}\end{array}$ & & & \\
\hline $\begin{array}{l}\text { Dollar-denom. Int'l debt }(\%) \\
\text { Financial Inst. }\end{array}$ & & & & $\begin{array}{l}-2.646 \\
(2.431)\end{array}$ & & & & & & $\begin{array}{l}-3.242 \\
(3.148)\end{array}$ & & \\
\hline $\begin{array}{l}\text { Dollar share x US gamma } \\
\text { Financial Inst. }\end{array}$ & & & & $\begin{array}{c}6.007 \\
(2.520)^{* *}\end{array}$ & & & & & & $\begin{array}{c}8.341 \\
(2.674)^{* * *}\end{array}$ & & \\
\hline $\begin{array}{l}\text { Dollar-denom. Int'l debt }(\%) \\
\text { Non-Financial Inst. }\end{array}$ & & & & & $\begin{array}{l}-0.859 \\
(2.653)\end{array}$ & & & & & & $\begin{array}{l}-2.902 \\
(3.118)\end{array}$ & \\
\hline $\begin{array}{l}\text { Dollar share x US gamma } \\
\text { Non-Financial Inst. }\end{array}$ & & & & & $\begin{array}{c}8.736 \\
(2.466)^{* * *}\end{array}$ & & & & & & $\begin{array}{c}9.585 \\
(2.603) * * *\end{array}$ & \\
\hline $\begin{array}{c}\text { Dollar-denom. Int'l debt }(\%) \backslash \\
\text { Gov't sector }\end{array}$ & & & & & & $\begin{array}{l}-5.318 \\
(2.803)^{*}\end{array}$ & & & & & & $\begin{array}{l}-4.051 \\
(2.939)\end{array}$ \\
\hline $\begin{array}{l}\text { Dollar share x US gamma } \\
\text { Gov't Sector }\end{array}$ & & & & & & $\begin{array}{c}3.476 \\
(2.688)\end{array}$ & & & & & & $\begin{array}{l}4.041 \\
(2.748)\end{array}$ \\
\hline $\mathrm{N}$ & 782 & 550 & 502 & 530 & 415 & 526 & 581 & 445 & 365 & 426 & 373 & 459 \\
\hline Adj. R2 & 0.06 & 0.14 & 0.09 & 0.11 & 0.13 & 0.09 & 0.04 & 0.12 & 0.11 & 0.10 & 0.12 & 0.05 \\
\hline \# of countries & 61 & 39 & 42 & 44 & 33 & 42 & 38 & 29 & 24 & 32 & 27 & 33 \\
\hline
\end{tabular}


Link 5-CEs: REER changes $\rightarrow$ PH: Stock market price changes

\begin{tabular}{|c|c|c|c|c|c|c|c|c|c|c|c|c|}
\hline & \multicolumn{6}{|c|}{ Developing Countries (LDC) } & \multicolumn{6}{|c|}{ Emerging Market Countries (EMG) } \\
\hline & (1) & (2) & (3) & (4) & (5) & (6) & (7) & (8) & (9) & (10) & (11) & (12) \\
\hline Exch. Rate Stability & $\begin{array}{l}0.246 \\
(0.254)\end{array}$ & $\begin{array}{c}0.008 \\
(0.254)\end{array}$ & $\begin{array}{c}1.191 \\
(0.424)^{* * *}\end{array}$ & $\begin{array}{l}-0.268 \\
(0.288)\end{array}$ & $\begin{array}{l}-0.184 \\
(0.354)\end{array}$ & $\begin{array}{l}0.358 \\
(0.330)\end{array}$ & $\begin{array}{l}0.394 \\
(0.316)\end{array}$ & $\begin{array}{l}0.133 \\
(0.304)\end{array}$ & $\begin{array}{c}1.164 \\
(0.504)^{* *}\end{array}$ & $\begin{array}{l}-0.267 \\
(0.356)\end{array}$ & $\begin{array}{l}-0.120 \\
(0.387)\end{array}$ & $\begin{array}{l}0.245 \\
(0.361)\end{array}$ \\
\hline Financial Openness & $\begin{array}{l}0.060 \\
(0.197)\end{array}$ & $\begin{array}{l}0.327 \\
(0.213)\end{array}$ & $\begin{array}{l}0.254 \\
(0.310)\end{array}$ & $\begin{array}{l}0.346 \\
(0.226)\end{array}$ & $\begin{array}{l}0.322 \\
(0.276)\end{array}$ & $\begin{array}{l}0.003 \\
(0.249)\end{array}$ & $\begin{array}{l}0.115 \\
(0.245)\end{array}$ & $\begin{array}{l}0.369 \\
(0.241)\end{array}$ & $\begin{array}{l}0.109 \\
(0.358)\end{array}$ & $\begin{array}{l}0.258 \\
(0.266)\end{array}$ & $\begin{array}{l}0.239 \\
(0.286)\end{array}$ & $\begin{array}{l}0.033 \\
(0.263)\end{array}$ \\
\hline IR Holding & $\begin{array}{l}-0.590 \\
(0.567)\end{array}$ & $\begin{array}{l}-0.642 \\
(0.599)\end{array}$ & $\begin{array}{c}-1.886 \\
(0.892) * *\end{array}$ & $\begin{array}{l}-0.585 \\
(0.598)\end{array}$ & $\begin{array}{l}-1.634 \\
(0.874)^{*}\end{array}$ & $\begin{array}{c}-1.526 \\
(0.743)^{* *}\end{array}$ & $\begin{array}{l}-1.252 \\
(0.801)\end{array}$ & $\begin{array}{c}-1.608 \\
(0.806)^{* *}\end{array}$ & $\begin{array}{l}-3.206 \\
(1.359)^{* *}\end{array}$ & $\begin{array}{l}-1.437 \\
(0.855)^{*}\end{array}$ & $\begin{array}{l}-1.481 \\
(0.924)\end{array}$ & $\begin{array}{c}-2.165 \\
(0.967)^{* *}\end{array}$ \\
\hline Dollar-denom. Int'l debt $(\%)$ & & $\begin{array}{c}0.829 \\
(0.258)^{* * *}\end{array}$ & & & & & & $\begin{array}{c}1.031 \\
(0.325)^{* * *}\end{array}$ & & & & \\
\hline Dollar share x US gamma & & $\begin{array}{c}-1.447 \\
(0.231)^{* * *}\end{array}$ & & & & & & $\begin{array}{c}-1.617 \\
(0.249)^{* * *}\end{array}$ & & & & \\
\hline $\begin{array}{l}\text { Public debt } \\
\text { denominated in USD (\%) }\end{array}$ & & & $\begin{array}{l}-0.249 \\
(0.474)\end{array}$ & & & & & & $\begin{array}{l}-0.387 \\
(0.497)\end{array}$ & & & \\
\hline Dollar share (PPG) x US gamma & & & $\begin{array}{c}-1.919 \\
(0.491)^{* * *}\end{array}$ & & & & & & $\begin{array}{c}-1.864 \\
(0.503)^{* * *}\end{array}$ & & & \\
\hline $\begin{array}{l}\text { Dollar-denom. Int'l debt }(\%) \\
\text { Financial Inst. }\end{array}$ & & & & $\begin{array}{c}0.568 \\
(0.218)^{* * *}\end{array}$ & & & & & & 0.618 & & \\
\hline $\begin{array}{l}\text { Financial Inst. } \\
\text { Dollar share x US gamma }\end{array}$ & & & & $\begin{array}{l}(0.218) \\
-1.408\end{array}$ & & & & & & $\begin{array}{c}(0.287)^{* *} \\
-1.621\end{array}$ & & \\
\hline Financial Inst. & & & & $(0.217)^{* * *}$ & & & & & & $(0.236)^{* * *}$ & & \\
\hline Dollar-denom. Int'l debt $(\%)$ & & & & & 0.258 & & & & & & 0.284 & \\
\hline Non-Financial Inst. & & & & & $(0.259)$ & & & & & & $(0.297)$ & \\
\hline $\begin{array}{l}\text { Dollar share x US gamma } \\
\text { Non-Financial Inst. }\end{array}$ & & & & & $\begin{array}{c}-1.752 \\
(0.245)^{* * *}\end{array}$ & & & & & & $\begin{array}{c}-1.791 \\
(0.253) * * *\end{array}$ & \\
\hline Dollar-denom. Int'l debt(\%)\} $&{ } &{ } &{ } &{ } &{ } &{0.847} &{ } &{ } &{ } &{ } &{ } &{0.894} \\
{\hline \text { Gov't sector }} &{ } &{ } &{ } &{ } &{ } &{(0.279)^{* * *}} &{ } &{ } &{ } &{ } &{ } &{(0.304)^{* * *}} \\
{\hline \begin{array}{l}\text { Dollar share x US gamma } \\
\text { Gov't Sector }\end{array}} &{ } &{ } &{ } &{ } &{ } &{\begin{array}{c}-1.463 \\
(0.282)^{* * *}\end{array}} &{ } &{ } &{ } &{ } &{ } &{\begin{array}{c}-1.441 \\
(0.289)^{* * *}\end{array}} \\
{\hline \mathrm{N}} &{570} &{470} &{310} &{451} &{374} &{423} &{473} &{401} &{271} &{391} &{350} &{381} \\
{\hline \text { Adj. R2 }} &{0.12} &{0.24} &{0.21} &{0.25} &{0.28} &{0.22} &{0.13} &{0.26} &{0.20} &{0.27} &{0.28} &{0.24} \\
{\hline \text { \# of countries }} &{40} &{33} &{22} &{36} &{27} &{31} &{32} &{27} &{18} &{29} &{25} &{27} \\
$\hline
\end{tabular}


Table 6: Summary of the Findings (for LDCs and EMGs)

\begin{tabular}{|c|c|}
\hline Link & Factors \\
\hline $\begin{array}{l}\text { Link } 1 \\
\text { CEs: ST rate in the CEs } \rightarrow \text { PHs: ST rate }\end{array}$ & 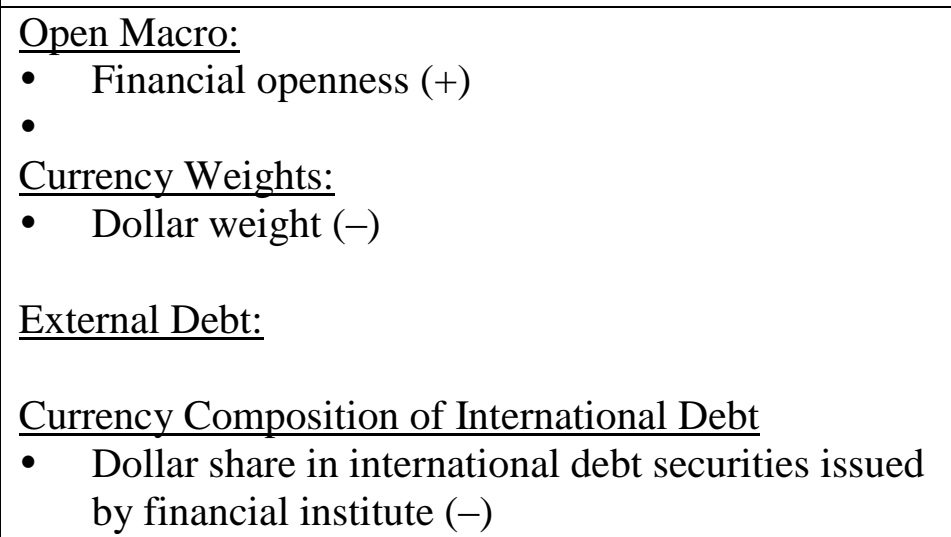 \\
\hline $\begin{array}{l}\text { Link } 2 \\
\text { CEs: Change in ST-rate } \\
\quad \rightarrow \text { PH: REER changes }\end{array}$ & 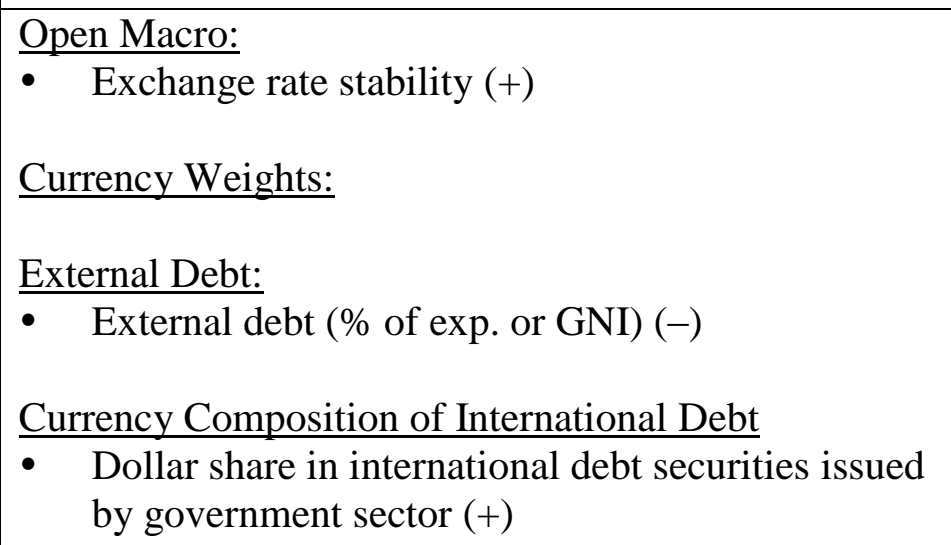 \\
\hline $\begin{array}{l}\text { Link } 3 \\
\text { CEs: Change in REER } \\
\quad \rightarrow \text { PHs: Change in REER }\end{array}$ & 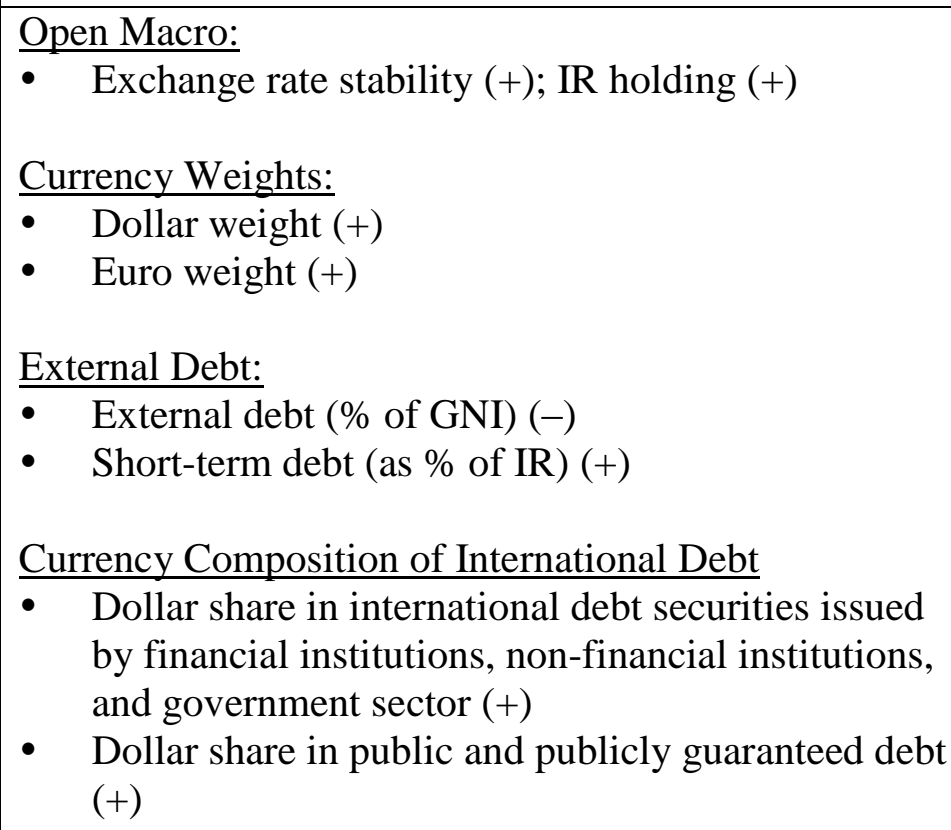 \\
\hline Link 4 & $\begin{array}{l}\text { Open Macro: } \\
\text { - Exchange rate stability }(-) \text {; Financial openness }(-)\end{array}$ \\
\hline
\end{tabular}




\begin{tabular}{|c|c|}
\hline CEs: REER changes $\rightarrow$ PHs: EMP & $\begin{array}{l}\text { Currency Weights: } \\
\text { - } \quad \text { Dollar weight }(+) \\
\text { Euro weight }(-) \\
\text { External Debt: } \\
\text { - } \quad \text { External debt }(\% \text { of exp. })(+) \\
\text { ST debt }(\% \text { of exp. or total ext. debt })(+) \\
\text { Currency Composition of International Debt } \\
\text { - } \quad \text { Dollar share in international debt securities issued } \\
\text { by financial institutions and non-financial } \\
\text { institutions }(+) \\
\text { Dollar share in public and publicly guaranteed debt } \\
(+)\end{array}$ \\
\hline $\begin{array}{l}\text { Link } 5 \\
\text { CEs: REER changes } \\
\quad \rightarrow \text { PH: Stock market price changes }\end{array}$ & 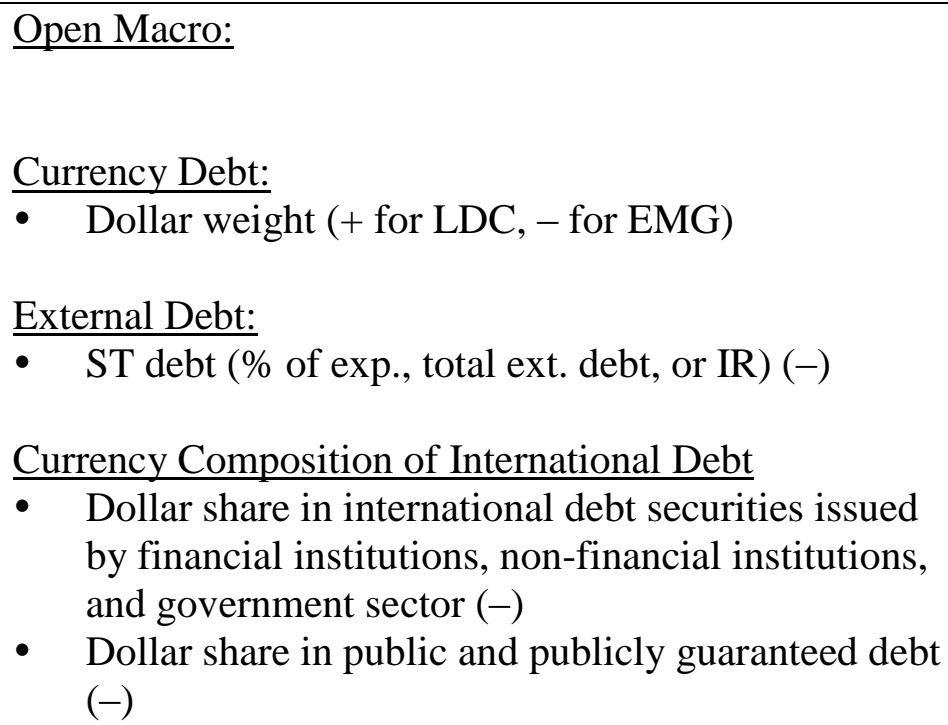 \\
\hline
\end{tabular}


Figure 1: Five Linkages

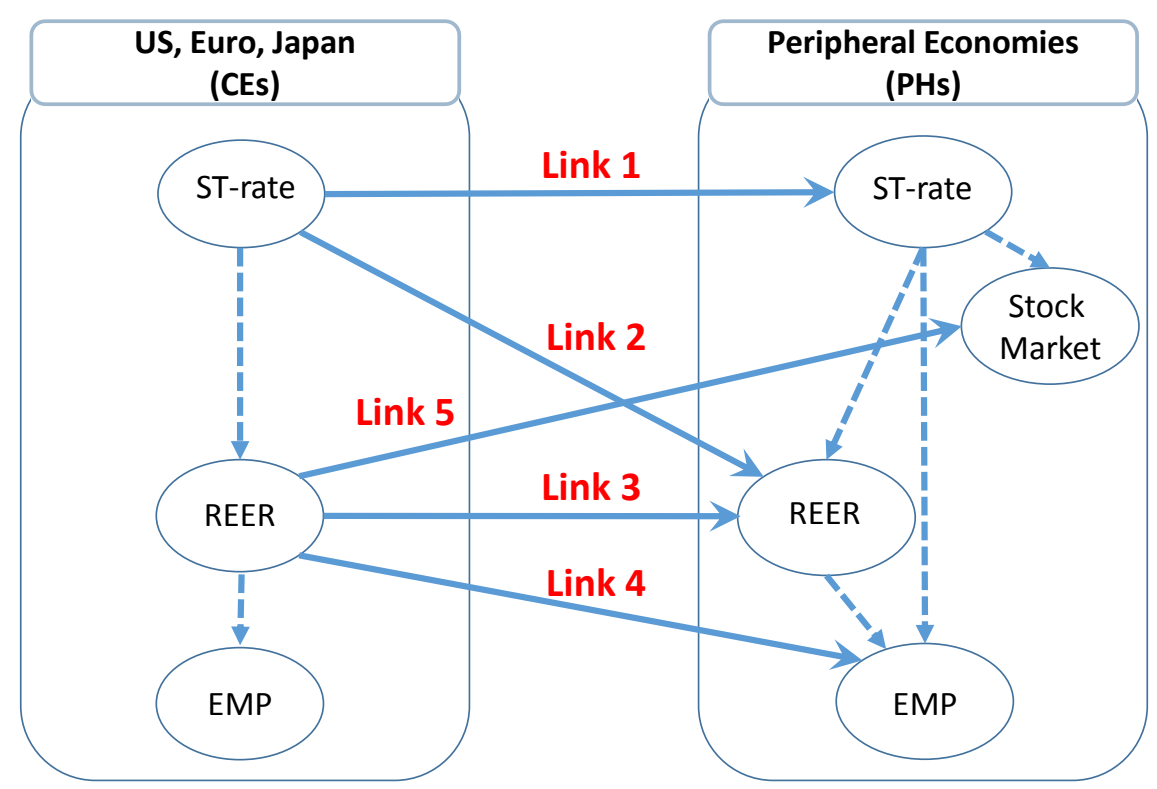


Figure 2: Proportion of Significant F-Tests

(i) CE: Policy Interest Rate $\rightarrow$ PH: Policy Interest Rate
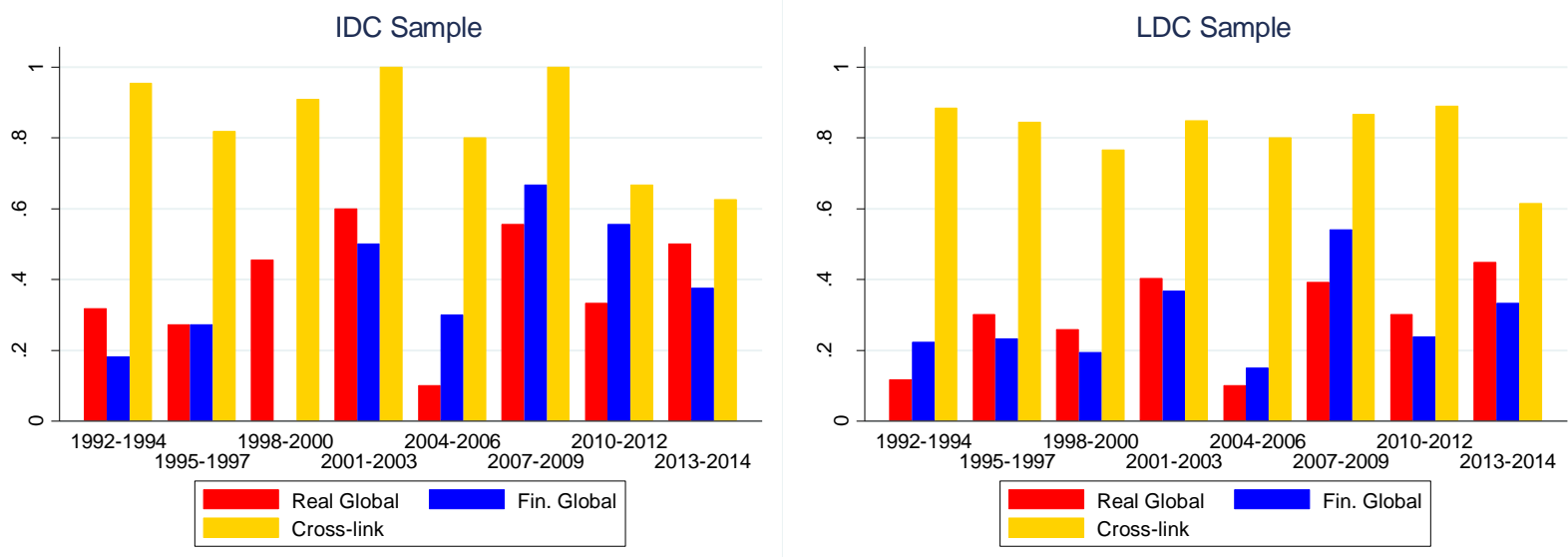

(ii) CE: Policy Interest Rate $\rightarrow$ PH: REER
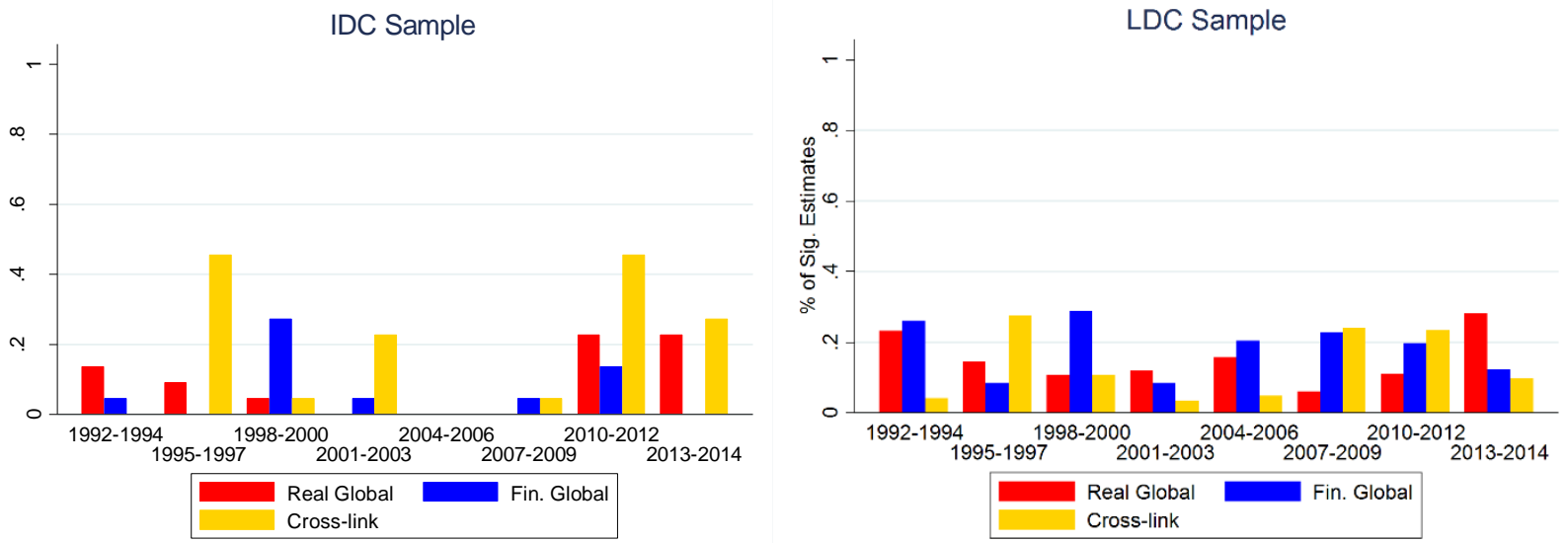

(iii) CE: REER $\rightarrow$ PH: REER
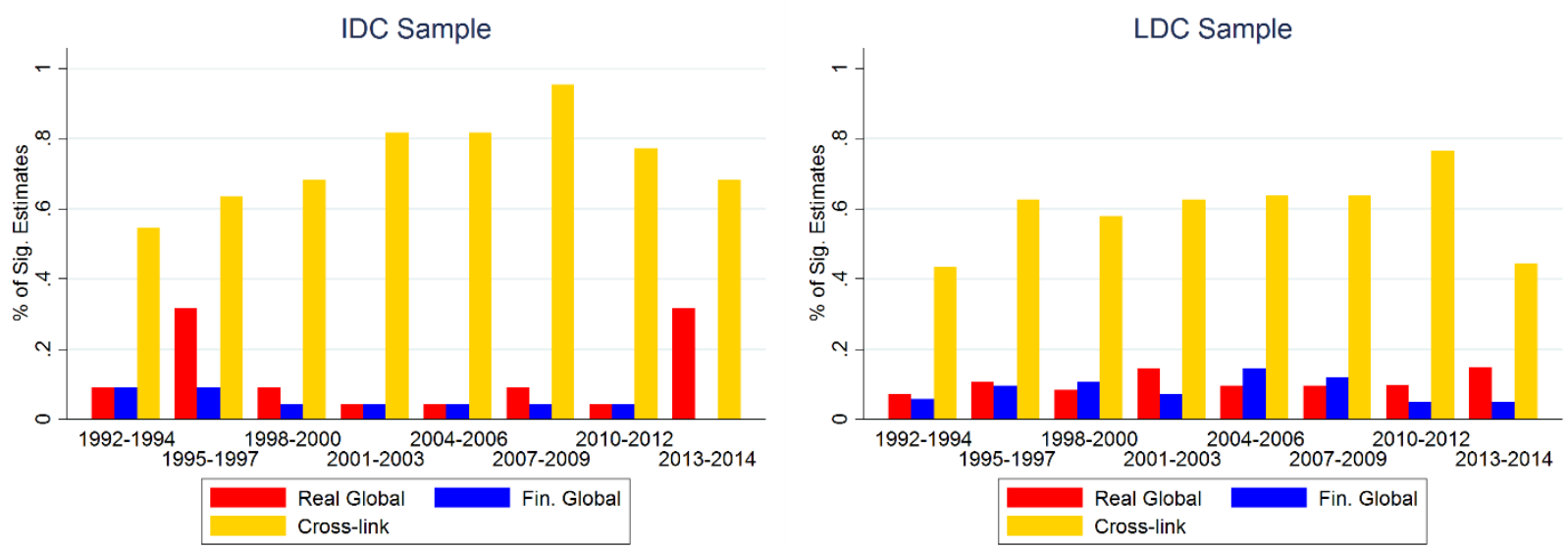
Figure 2: Continued

(iv) CE: REER $\rightarrow$ PH: EMP
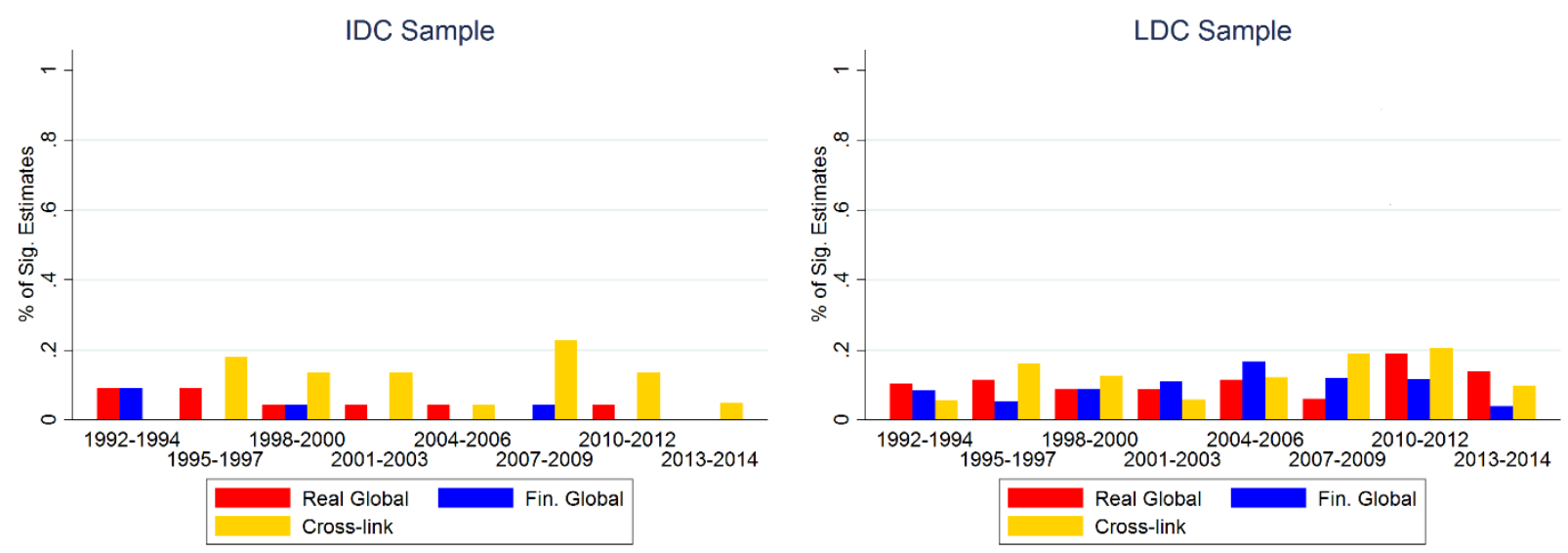

(v) CE: REER $\rightarrow$ PH: Stock market price change
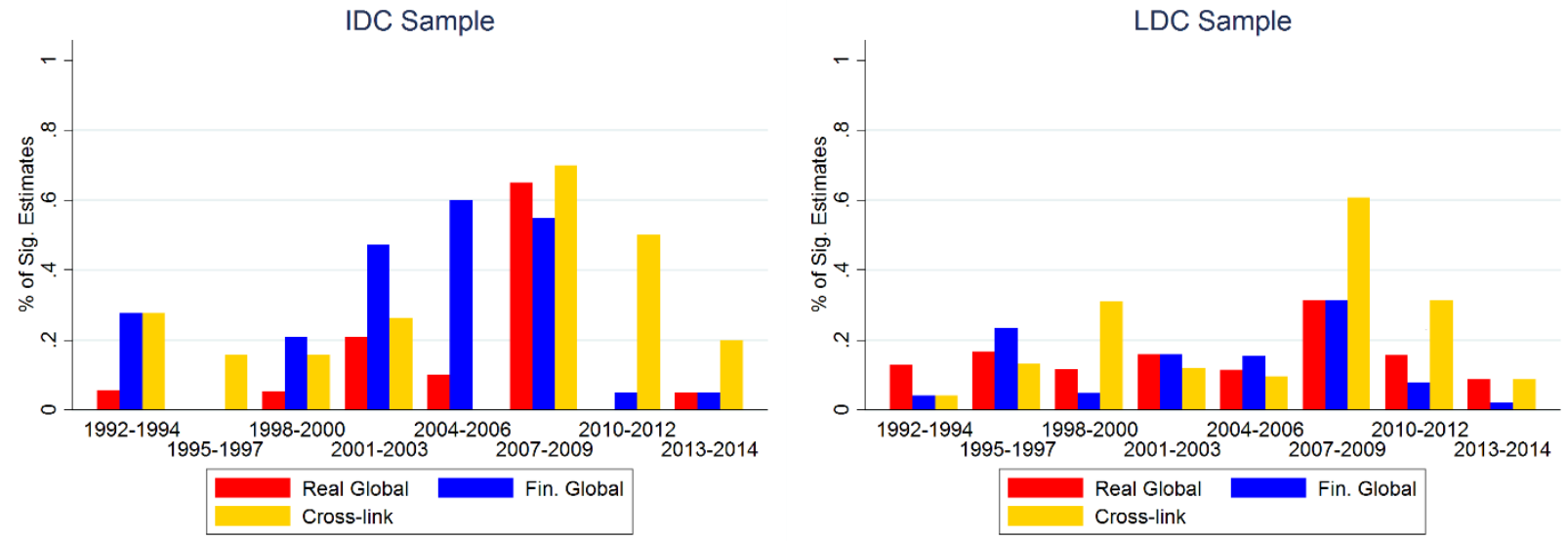


\section{Figure 3: Proportion of Significant $\widehat{\gamma}$ 's}

(i) CE: Policy Interest Rate $\rightarrow$ PH: Policy Interest Rate

LDC
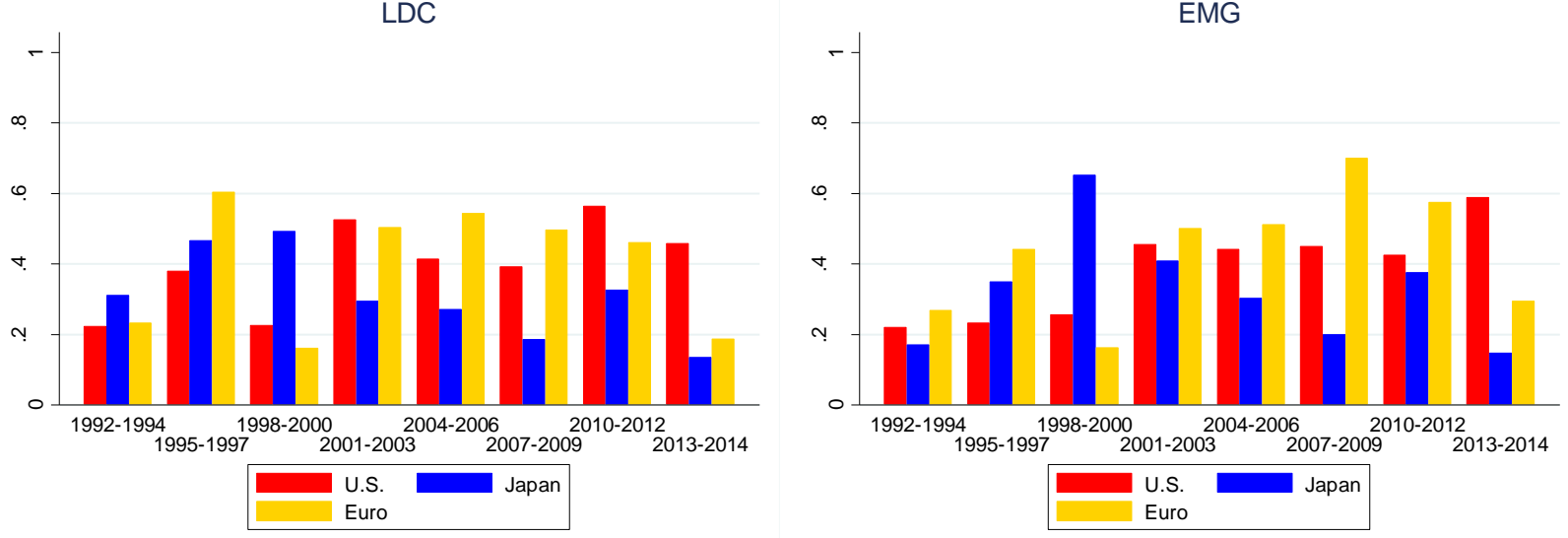

(ii) CE: Policy Interest Rate $\rightarrow$ PH: REER
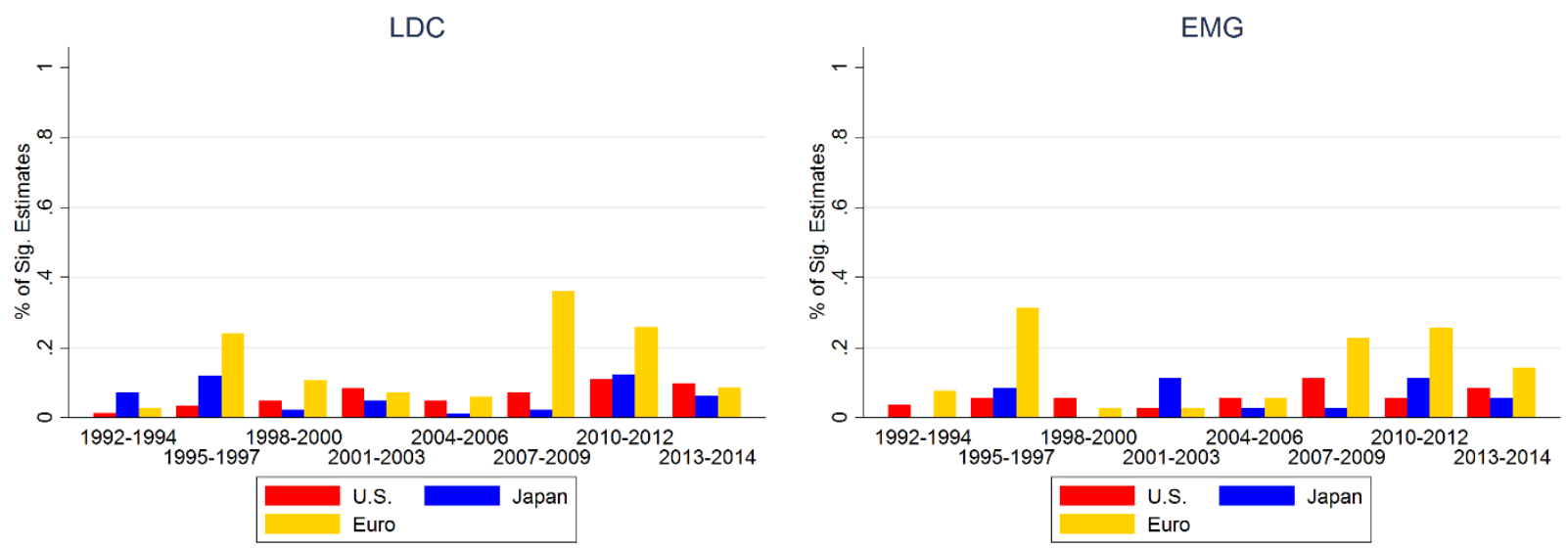

(iii) CE: REER $\rightarrow$ PH: REER

LDC
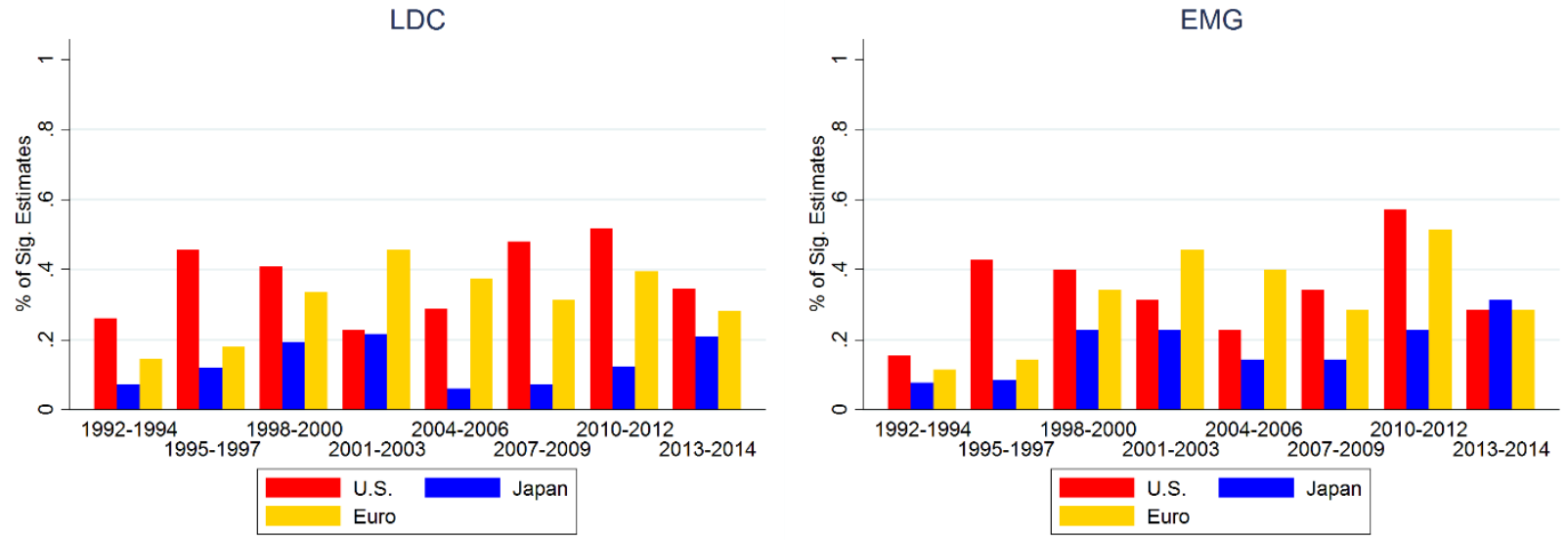
Figure 3: Continued

(iv) CE: REER $\rightarrow \mathrm{PH}$ : EMP

LDC

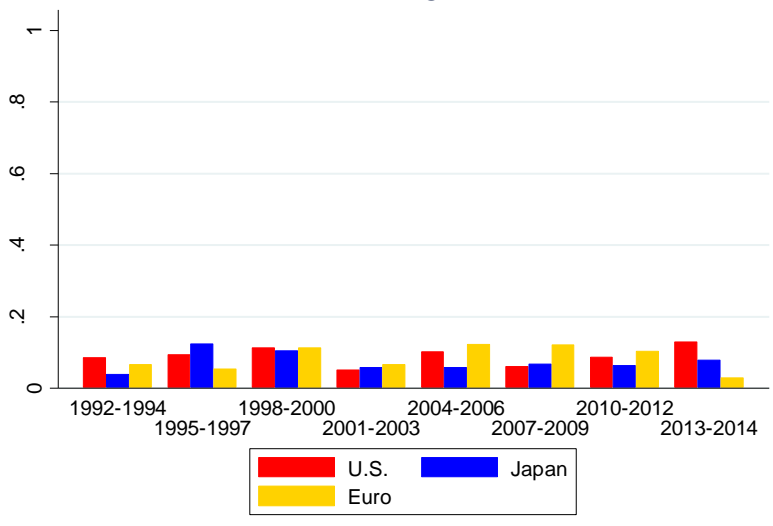

EMG

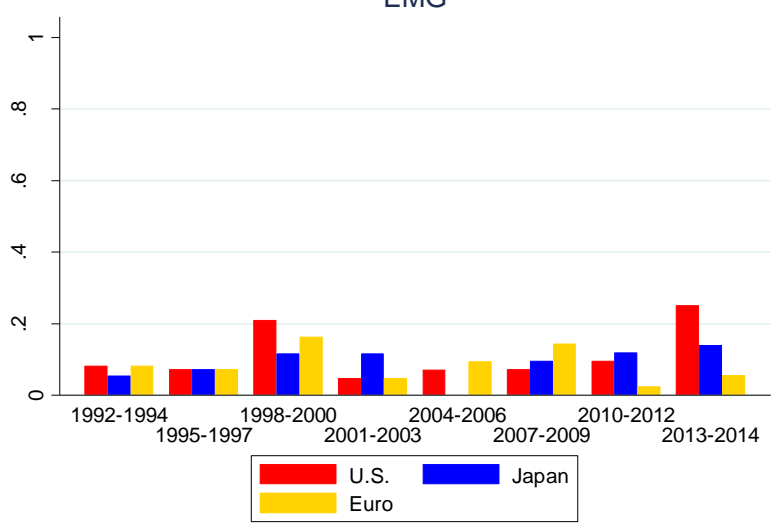

(v) CE: REER $\rightarrow$ PH: Stock market price change
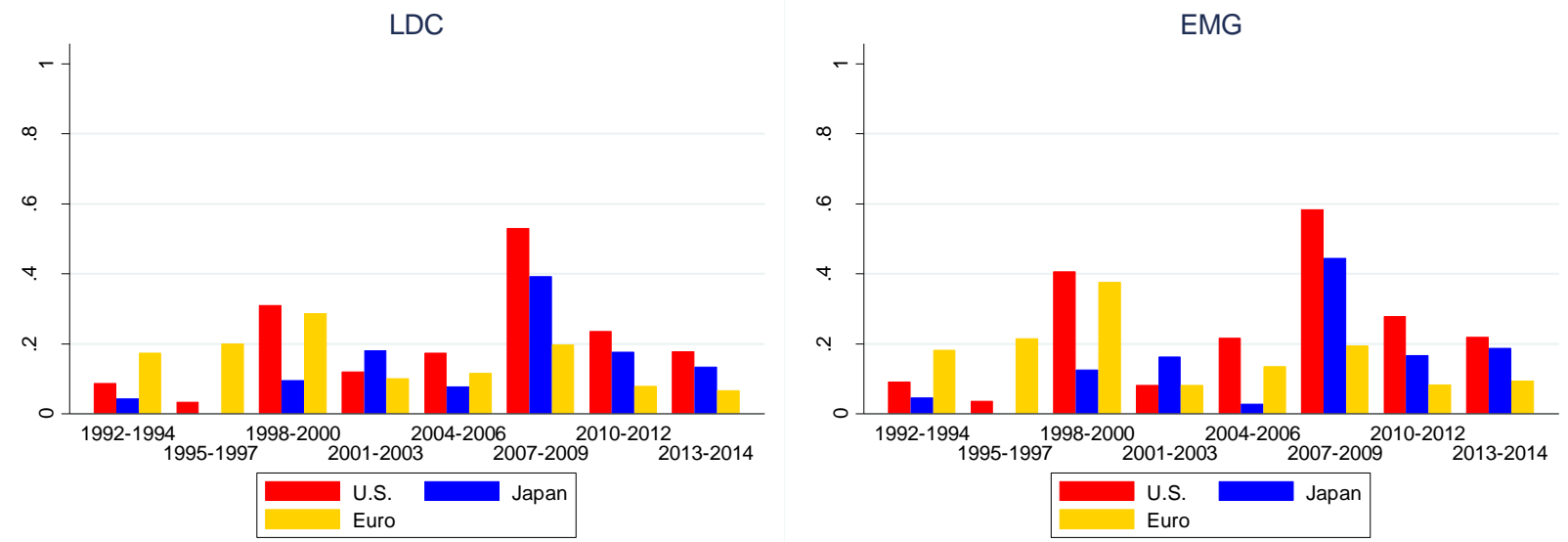